Review

\title{
NCA, NCM811, and the Route to Ni-Richer Lithium-Ion Batteries
}

\author{
Christian M. Julien * (D) and Alain Mauger \\ Institut de Minéralogie, de Physique des Matériaux et de Cosmologie (IMPMC), Sorbonne Université, \\ CNRS-UMR 7590, 4 Place Jussieu, 75252 Paris, France; alain.mauger@sorbonne-universite.fr \\ * Correspondence: christian.julien@sorbonne-universite.fr
}

Received: 10 October 2020; Accepted: 30 November 2020; Published: 2 December 2020

\begin{abstract}
The aim of this article is to examine the progress achieved in the recent years on two advanced cathode materials for $\mathrm{EV} \mathrm{Li}$-ion batteries, namely Ni-rich layered oxides $\mathrm{LiNi}_{0.8} \mathrm{Co}_{0.15} \mathrm{Al}_{0.05} \mathrm{O}_{2}(\mathrm{NCA})$ and $\mathrm{LiNi}_{0.8} \mathrm{Co}_{0.1} \mathrm{Mn}_{0.1} \mathrm{O}_{2}$ (NCM811). Both materials have the common layered (two-dimensional) crystal network isostructural with $\mathrm{LiCoO}_{2}$. The performance of these electrode materials are examined, the mitigation of their drawbacks (i.e., antisite defects, microcracks, surface side reactions) are discussed, together with the prospect on a next generation of Li-ion batteries with Co-free Ni-rich Li-ion batteries.
\end{abstract}

Keywords: Ni-rich cathodes; two-dimensional materials; Li-ion batteries; powering electric vehicle

\section{Introduction}

Major challenges of the 21st century concern the global climate change and dwindling fossil energy reserves that motivate the scientific community to develop sustainable solutions based on renewable sources of energy, which require accumulators to store electricity, i.e., rechargeable (secondary) batteries. Since their first commercialization in 1991 by Sony Corp., lithium-ion batteries (LIBs) have penetrated the mass market as power sources. The reason of this success is explained by the performance of the Li-ion battery technology. Depending on the choice of the electrodes, the volumetric energy density of LIBs is in the range $200-350 \mathrm{Wh} \mathrm{L}^{-1}$ and on average the gravimetric density is $150 \mathrm{Wh} \mathrm{kg}^{-1}$. This outperforms the other electrochemical batteries (Pb-acid, Ni-Cd Ni-MH). For some applications, these other batteries are still of interest because they are less expensive. However, the choice of Li-ion is mandatory when higher energy and power densities are needed. Such is the case when volume is a key parameter: batteries for phones, cameras, computers for instance. This is also the case when both energy density and volume densities are important parameters, such as batteries for electric vehicles. Other current applications concern batteries used to solve the intermittence problems of the electricity produced by wind or photovoltaic plants, more and more developed as renewable energy sources, and considered as the only solution to give access of electricity to the sub-Saharan countries in Africa. The initial LIB chemistry consisted of lithium cobaltate $\mathrm{LiCoO}_{2}$ (LCO) as positive electrode (cathode) and carbon (graphite) as negative electrode (anode) in between of which a separator soaked with an organic electrolyte (ionic conductor) [1]. Now, the energy density of LCO-based LIBs has reached the value of $280 \mathrm{Wh} \mathrm{kg}^{-1}$ (700 Wh L ${ }^{-1}$ ) [2], which explains that LCO still occupies most of the market in the field of portable electronics.

The main drawback of all the cathode materials in such batteries is the limited rate capability because of a low ionic and/or electronic conduction [3]. The sluggish kinetics impose the fabrication of redox-effective particles as small as possible to reduce the diffusion path length of the lithium inside the particles. That is why many efforts have been made to reduce their size to the nanoscale. The electrode material performance reached today is above all the benefit of the progress in nanoscience. Okubo et 
al. [4] have observed an increased rate capability of $\mathrm{LiCoO}_{2}$ when the size of the particles was reduced to $17 \mathrm{~nm}$, with a capacity delivered at $100 \mathrm{C}$ as high as $62.5 \%$ of the capacity at $1 \mathrm{C}$.

LCO presents the disadvantages of high price, cobalt toxicity and a rather small capacity $\left(\approx 140 \mathrm{mAh} \mathrm{g}^{-1}\right)$ due to oxygen loss in the partially delithiated $\mathrm{Li}_{1-\mathrm{x}} \mathrm{CoO}_{2}$ cathode $(x \approx 0.5)$. For these reasons, in addition to safety issues, LCO cannot be used as power supply for electric vehicles (EVs). Increase of the driving range of EVs is needed to increase the market of EVs and replace the petrol cars by EVs to meet the ambitious goal of reduction of $\mathrm{CO}_{2}$ emission $\left(95 \mathrm{~g}_{\mathrm{CO}_{2}} / \mathrm{km}\right.$ mandated by E.U.) [5]. The energy density E must satisfy the relation $E=Q V$, which imposes high operating cell voltage $(V)$ and large stored capacity $(Q)$ delivered to loads. High cell voltage can be obtained using an anode material with a potential close to that of Li metal (3.04 V vs. standard hydrogen electrode (SHE)) and a high-voltage cathode ( $>0.5 \mathrm{~V}$ vs. SHE); moreover, according to the Faraday law $\left(Q=n F / M_{\mathrm{W}}\right)$, the capacity is determined by the number of transferred electrons $(\mathrm{n})$ and the molar weight of the active electrode material $\left(M_{\mathrm{W}}\right)$. Since it is difficult to avoid the use of graphite as an anode, for reasons discussed elsewhere [3], the most feasible method involves an increase of the capacity and working voltage of the cathode. Various compounds with two- and tri-dimensional structures have been intensively investigated as cathode materials: $\mathrm{LiCoO}_{2}$ (LCO), $\mathrm{LiMn}_{2} \mathrm{O}_{4}$ (LMO), $\mathrm{LiFePO}_{4}(\mathrm{LFP}), \mathrm{LiNi}_{\mathrm{x}} \mathrm{Co}_{y} \mathrm{Mn}_{z} \mathrm{O}_{2}(\mathrm{NCM})$, and $\mathrm{LiNi}_{x} \mathrm{Co}_{\mathrm{y}} \mathrm{Al}_{\mathrm{z}} \mathrm{O}_{2}$ (NCA) with $x+y+z=1$ [2,3]. Among them, two Ni-rich layered oxides, $\mathrm{LiNi}_{0.8} \mathrm{Co}_{0.15} \mathrm{Al}_{0.05} \mathrm{O}_{2}(\mathrm{NCA})$ and $\mathrm{LiNi}_{0.8} \mathrm{Co}_{0.1} \mathrm{Mn}_{0.1} \mathrm{O}_{2}(\mathrm{NCM} 811)$ are increasingly popular active cathode elements used in commercial LIBs for electric cars and planes. The first reason is that the redox activity of nickel occurs at higher potential vs. $\mathrm{Li}^{+} / \mathrm{Li}$ than iron in LFP or $\mathrm{Mn}$ in $\mathrm{LMO}$. This composition $\mathrm{LiNi}_{0.8} \mathrm{Co}_{0.15} \mathrm{Al}_{0.05} \mathrm{O}_{2}$ for the NCA material imposed itself because it is less expensive and is more environmentally benign than other compositions [6-8]. On another hand, $\mathrm{Li}\left[\mathrm{Ni}_{\mathrm{x}} \mathrm{Co}_{\mathrm{y}} \mathrm{Mn}_{\mathrm{z}}\right] \mathrm{O}_{2}$ has been investigated at different $\mathrm{Ni}$ concentrations since, the early works of Ohzuku's [9,10] and Dahn's [11,12] groups, with focus on $x: y: z=5: 3: 2$ (NCM532), 6:2:2 (NCM622), and 8:1:1 (NCM811) for applications requiring high density. The larger Ni fraction, the higher energy density, since Ni is the redox-active element both in NCA and NCM. This increase in Ni concentration, however, is accompanied with a decrease in structural and thermal stability due to the weaker Ni-O bonds, and thus a decrease in cycling ability. In addition, the chemical reactivity of the surface layer is increased due to the more oxidizing $\mathrm{Ni}^{3+} / \mathrm{Ni}^{4+}$ redox potential. The degradation mechanisms for all the ternary Ni-based cathode materials at high voltage have been discussed by Zhang et al. [13]. Surface modification of the Ni-rich materials is the standard process used to improve the structural stability and protect the cathode element against side reactions with the electrolyte. This will be reviewed below. However, this process presents some drawbacks for Ni concentrations larger than $0.8[14,15]$. Homogeneous coating often requires a wet-coating process using a liquid. However, the surface is altered in the process, because the liquid medium reacts with $\mathrm{Ni}^{3+}$ to form impurity compounds, which degrades the electrochemical properties when the Ni concentration is too large, in practice when $x>0.8$. Other methods, including chemical vapor deposition (CVD), atomic layer deposition (ALD) can be used to obtain homogeneous coatings, but they are expensive and not viable from a commercial point of view. Moreover, the problem of microcrack generation and subsequent electrolyte infiltration, which decreases the cycling life, is a major problem for $x>0.8$. The compromise for practical use of these $\mathrm{N}$-rich cathodes is currently a Ni concentration $x=0.8$, even though we shall comment on the recent progress to overcome this difficulty. That is why the interest in this work is focused on NCM811 that has this fraction of nickel, the same as that of NCA. In practice this is the highest Ni concentration that can be used, because NCM with higher Ni concentration (like NCA) suffer from their low cycling stability [16]. This is illustrated in Figure 1. The degradation of Ni-rich NCM and NCA materials with different compositions was addressed by Sun et al. [17].

The aim of this article is to examine these two advanced cathode materials for EV Li-ion batteries that are already commercialized as lithium-ion batteries in the electric vehicle market $[18,19]$. Both materials have the common layered (two-dimensional) crystal architecture isostructural with $\mathrm{LiCoO}_{2}$. 
As we mentioned, nanosized particles have major advantages. In addition, nanosized particles can accommodate the volume change during cycling while microcracking occurs during cycling, which nucleate preferentially at the grain boundaries. Therefore, single crystallized particles, which can be synthesized only at the nanoscale, minimize the risk of microcracking responsible for a shortage of the cycle life in the materials considered in this review [20]. In practice, however, it is difficult to use monodisperse particles of a nanosize. First, smaller particles tend to agglomerate, and nanopowders are difficult to handle at the industrial scale. Moreover, commercial cathodes contain a mix of large and small particles, which is needed to increase the packing density. However, the presence of the smaller particles is always needed to insure a good electrochemical performance. Smaller particles also means increased effective surface between the cathode materials and the electrolyte, thus raising the problem of the side reactions at the cathode-electrolyte interface (CEI). As we shall see, the control of the CEI is the major difficulty met with the Ni-rich materials, together with the formation of microcracks during cycling that favor the penetration of the electrolyte to form insulating CEI limiting cycle life of the batteries. In this work, we review the solutions that have been found to overcome these difficulties, opening the route to a new generation of LIBs with enhanced energy density. After a brief description of the structural characteristics, we report some electrochemical properties to highlight the performance of these electrodes, and review the state-of-the-art in the methods of atomic doping and surface coating to improve the limited cycle ability and rate capability of the NCA and NCM cathodes.

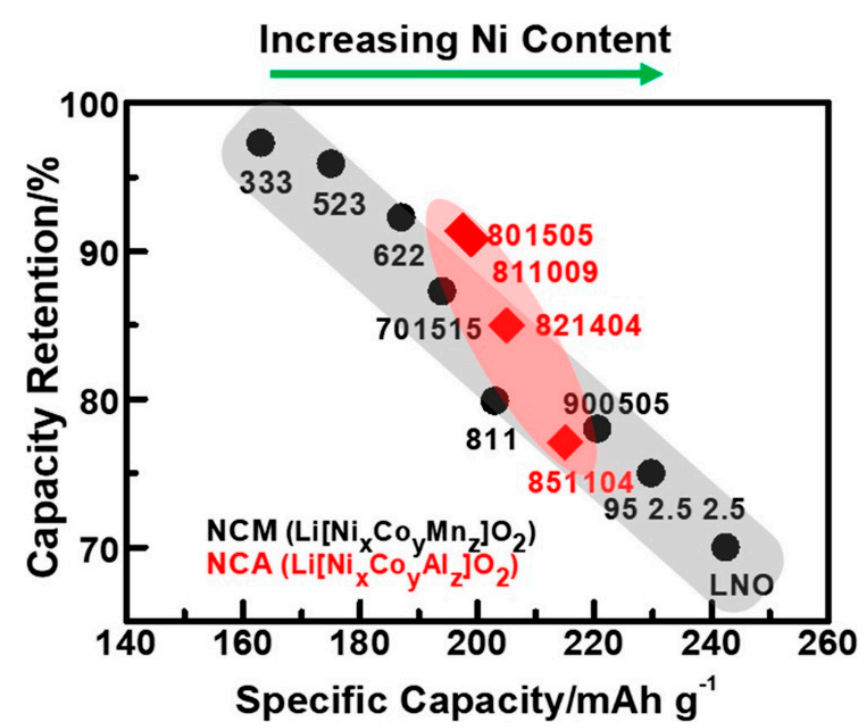

Figure 1. Specific capacity $\left(\mathrm{mAh} \mathrm{g}^{-1}\right.$ ) versus capacity retention over 100 cycles (\%) plot of various layered NCM and NCA cathodes showing the trade-off between stability and capacity at increasing Ni content. Compounds are labelled by their composition $(\mathrm{Ni}, \mathrm{Co}, \mathrm{Mn})=x: y: z$. Reproduced from [16]. Copyright 2017. The American Chemical Society.

\section{Structure of Layered Lithiated Oxides}

Lithium transition-metal (TM) oxides $\mathrm{LiMO}_{2}(M=\mathrm{Co}, \mathrm{Ni}, \mathrm{Mn}, \mathrm{Cr})$ crystallize in the $\alpha-\mathrm{NaFeO}_{2}$ structure belonging to $R \overline{3} m\left(D_{3 d^{5}}\right)$ space group (S.G.). The same holds true for their related oxides $\mathrm{LiCoM} \mathrm{M}_{2}$ where $M^{\prime}$ is a divalent or trivalent substituting ion. In this lattice, the $\mathrm{Li}^{+}$ions are stacked between $\mathrm{MO}_{2}$ slabs. [21]. The octahedra are face-sharing. These oxides show high operating voltage $>3 \mathrm{~V}$ vs. $\mathrm{Li}$ due to the $d$-electron character of $\mathrm{TM}$. $\mathrm{LiN}_{1-\mathrm{y}} \mathrm{Co}_{\mathrm{y}} \mathrm{O}_{2}$ solid solutions belong to this family, and exist in all proportions between $\mathrm{LiNiO}_{2}$ and $\mathrm{LiCoO}_{2}$, because the radius of $\mathrm{Co}^{3+}$ ion $\left(r_{\mathrm{Co}}{ }^{3+}=0.545 \AA\right)$ is almost the same as that of $\mathrm{Ni}^{3+}$ ion $\left(r_{\mathrm{Ni}}{ }^{3+}=0.56 \AA\right)$ in octahedral site [22]. Schematic crystal structure of $\mathrm{O} 3-\mathrm{Li} M \mathrm{O}_{2}$ is shown in Figure 2. The "O3" label indicates that the Li environment is octahedral with $A B C A B C$ stacking order of the oxygen layers. As a result, the hexagonal unit cell includes three sets of $\mathrm{Co}$ and Li layers. 
$\mathrm{LiNiO}_{2}$ (LNO) cannot be an alternative to LCO, because of the cation mixing (CM), that is the migration of $\mathrm{Ni}$ ions from the intralayer plane ( $3 a$ sites) to the Li plane ( $3 b$ sites) [23]. This CM reduces the electrochemical performance and can lead to subsequent modification to spinel (cubic) structure. Three ways have been successful to minimize the $\mathrm{CM}$. The first one is the optimization of the synthesis process and synthesis parameters in $\mathrm{Li}_{1-x} \mathrm{Ni}_{1-y} \mathrm{Co}_{\mathrm{y}} \mathrm{O}_{2}$ [24]. This material does not show any loss of oxygen until $x=0.3$. In $\mathrm{LiNi}_{1 / 3} \mathrm{Mn}_{1 / 3} \mathrm{Co}_{1 / 3} \mathrm{O}_{2}$, a solid solution of $\mathrm{LiNiO}_{2}-\mathrm{LiCoO}_{2}-\mathrm{LiMnO}_{2}$, the cation mixing between lithium and nickel on the $3 b$ Wyckoff site implies that the chemical formula can also be written under the form $\left[\mathrm{Li}_{1-y} \mathrm{Ni}_{\mathrm{y}}\right]_{3 \mathrm{~b}}\left[\mathrm{Li}_{\mathrm{x}+\mathrm{y}} \mathrm{Ni}_{(1-\mathrm{x}) / 3-\mathrm{y}} \mathrm{Mn}_{(1-\mathrm{x}) / 3} \mathrm{Co}_{(1-\mathrm{x}) / 3}\right]_{3 \mathrm{a}} \mathrm{O}_{2}(x=0.01,0.04)$. Mn atoms are introduced in these materials to increase the structural stability. The second process to minimize the cation mixing is the partial substitution of aluminum for nickel. Recently, Nie et al. found a third process to minimize the cation mixing in NCA is the calcination of the material under an oxygen pressure of $0.6 \mathrm{MPa}$ [25]. In $\mathrm{LiNi}_{0.8} \mathrm{Co}_{0.15} \mathrm{Al}_{0.05} \mathrm{O}_{2}, \mathrm{Al}^{3+}$ cations $\left(r_{\mathrm{Al}}{ }^{3+}=0.53 \AA\right.$ similar to $\mathrm{Ni}^{3+}$ and $\mathrm{Co}^{3+}$ ) occupy the TM sites in the layered $R \overline{3} m$ crystal structure [26].
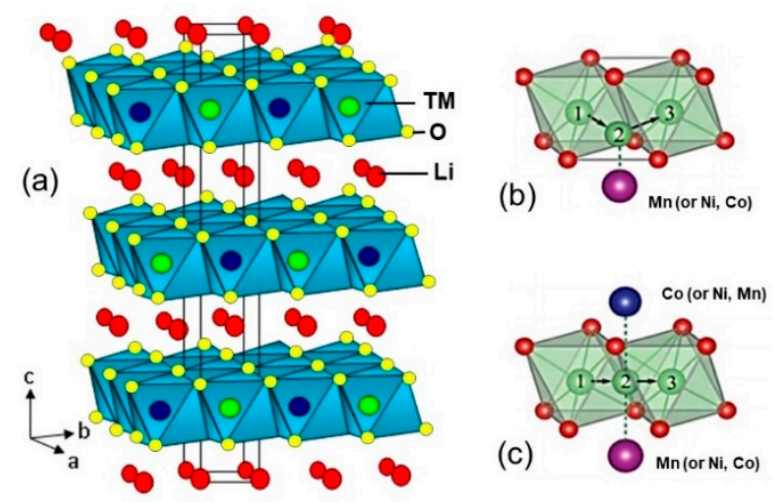

Figure 2. (a) Layered structure of NCM compound. Colors of atoms are green (Li), red (O), and silver/purple/blue are Ni, Mn, Co transition-metal cations, respectively. (b) Tetrahedral site pathway. (c) Oxygen dumbbell pathway for $\mathrm{Li}^{+}$ions.

\section{3. $\mathrm{LiNi}_{0.8} \mathrm{Co}_{0.15} \mathrm{Al}_{0.05} \mathrm{O}_{2}$ (NCA)}

\subsection{Synthesis}

Among the Ni-rich layered compounds, $\mathrm{LiNi}_{1-\mathrm{y}-\mathrm{z}} \mathrm{Co}_{\mathrm{y}} \mathrm{Al}_{\mathrm{z}} \mathrm{O}_{2}$ demonstrates superior electrochemical performance with respect to non-Al doped mixed $\mathrm{LiNi}_{1-y} \mathrm{Co}_{\mathrm{y}} \mathrm{O}_{2}$ materials owing to its structural and thermal stability $[27,28]$. Even though this electrode suffers from the serious side reactions with electrolyte and $\mathrm{HF}$ erosion, which reduces its cycle life, the particular composition $\mathrm{LiNi}_{0.80} \mathrm{Co}_{0.15} \mathrm{Al}_{0.05} \mathrm{O}_{2}$ is now used as the cathode in the 100-kWh battery pack of the Tesla EV Roadster by Tesla [29]. NCA-based batteries are also used by SAFT for various applications [30]. Majumdar et al. [31] used aluminum nitrate and metal acetates to prepare NCA via wet-chemical route. As a cathode, this powder cycled in the potential range 3.2-4.2 $\mathrm{V}$ delivered a capacity of $\approx 136 \mathrm{mAh} \mathrm{g}^{-1}$ at a current density $0.45 \mathrm{~mA} \mathrm{~cm}^{-2}$. NCA was also synthesized via a coprecipitation route with less than $1 \%$ antisite defects (Ni on Li sites) [32]. Usually, the coprecipitation method uses $\mathrm{NH}_{3} \mathrm{H}_{2} \mathrm{O}$ as the chelating agent, which produces by-products causing serious pollution problems. More recently, good results were obtained by using a different chelating agent, namely ethylenediaminetetraacetic acid (EDTA) [33]. Ropelike NCA fiber was prepared via electrospinning and sintering. As a cathode, it delivered a capacity of $206.4 \mathrm{mAh} \mathrm{g}^{-1}$ at $0.1 \mathrm{C}$, and maintained $75 \%$ capacity retention after 100 cycles at $1 \mathrm{C}$ [34]. A green and low-cost synthesis of NCA was also proposed, by using $\mathrm{C}_{4} \mathrm{H}_{4} \mathrm{O}_{6} \mathrm{KNa} \cdot 4 \mathrm{H}_{2} \mathrm{O}$ as a chelating agent to prepare $\mathrm{Ni}_{0.80} \mathrm{Co}_{0.15} \mathrm{Al}_{0.05}(\mathrm{OH})_{2}$ used as the precursor obtained through a coprecipitation method using potassium sodium tartrate [35]. Wu et al. used $\mathrm{SiO}_{2}$ hollow nanospheres as hard template to synthesize $\mathrm{LiNi}_{0.80} \mathrm{Co}_{0.15} \mathrm{Al}_{0.05} \mathrm{O}_{2}$ hollow nanospheres with a diameter of about $1.8 \mu \mathrm{m}$ (NCA HNSs). The NCA HNSs exhibited a reversible capacity of $202.4 \mathrm{mAh} \mathrm{g}^{-1}$ at $0.1 \mathrm{C}$ and $179.1 \mathrm{mAh} \mathrm{g}^{-1}$ after 80 
cycles at $1 \mathrm{C}$ rate [36]. $\mathrm{LiNi}_{0.80} \mathrm{Co}_{0.15} \mathrm{Al}_{0.05} \mathrm{O}_{2}$ was also recently synthesized via flame-assisted spray pyrolysis method as sui economical alternative in NCA mass production [37]. Such NCA particles showed the initial specific discharge capacity of $143 \mathrm{mAh} \mathrm{g}^{-1}$, and the capacity retention of $92 \%$ after 20 cycles. Indeed, the capacity outperforms that of commercial NCA available on the market $\left(138 \mathrm{mAh} \mathrm{g}^{-1}\right)$. NCA prepared by using N-methyl-2-pyrrolidone (NMP) and urea-based solvothermal reaction exhibited a capacity of $203 \mathrm{mAh} \mathrm{g}^{-1}$ at $0.1 \mathrm{C}$, and most of all excellent rate capability (117 $\mathrm{mAh} \mathrm{g}^{-1}$ at $10 \mathrm{C}, 74.4 \%$ capacity retention at $300^{\text {th }}$ cycle) attributed to enhanced exposure of $\{010\}$ planes [38].

\subsection{Degradation Mechanisms}

Bang et al. [39] investigated the thermal runaway of the delithiated cathode. The XRD spectra were recorded at different states-of-charge (SOCs). When the SOC increases, an increase in the distance between (018) and (110) Bragg lines at $2 \theta=65^{\circ}$ is observed, which gives evidence of an increase of the $c / a$ ratio in NCA [40]. The main problem to be solved with $\mathrm{LiNi}_{0.80} \mathrm{Co}_{0.15} \mathrm{Al}_{0.05} \mathrm{O}_{2}$ cathode is the rapid degradation upon cycling due to the well-known phase transition from a layered structure $(R \overline{3} m)$ to disordered spinel $(F d 3 m)$ which then transforms to the NiO-like rock-salt structures $(F m 3 m)$ in the surface layer [41-50]. This structural transformation is due to the strongly oxidizing $\mathrm{Ni}^{3+/ 4+}$ ions interacting with the electrolyte in the surface layer. It results in the formation of a resistive cathode-electrolyte interface and leads to loss of capacity and an increase of the impedance for $\mathrm{Li}^{+}$ diffusion [51-53] and a fatigue of the material [54-56]. Moreover, surface reconstructions occurring at charging voltages $>4.3 \mathrm{~V}$ or cycling above $40{ }^{\circ} \mathrm{C}$ trigger release of oxygen responsible for exothermic reactions with organic electrolytes [57-62] and thermal runaway [63,64]. In addition, Ni-rich materials undergo multiple phase transitions during cycling according to the sequence $\mathrm{H} 1 \rightarrow \mathrm{M} \rightarrow \mathrm{H} 2 \rightarrow \mathrm{H} 3$, where $\mathrm{H} 1$ is the layered structure, $\mathrm{M}$ a monoclinic phase, while $\mathrm{H} 2$ and $\mathrm{H} 3$ are hexagonal phases. The $\mathrm{H} 2 \rightarrow \mathrm{H} 3$ phase transition occurs at $\approx 4.2 \mathrm{~V}$ for $\mathrm{Ni}$ concentrations larger than 80 atomic $\% \mathrm{Ni}$ cathodes, and creates crack networks throughout the secondary particles of NCA [65], and NCM as well [66]. These crack networks along the grain boundaries are infiltrated by the electrolyte, resulting in the formation of an insulating NiO-type cathode-electrolyte interface [67,68]. Belharouak et al. [69] studied the thermal degradation of de-intercalated NCA samples. The authors reported that the oxygen release in the delithiated state was linked to several structural phase transitions, ranging from a $R m \rightarrow F d 3 m$ (layered $\rightarrow$ spinel) transition to a $F d 3 m \rightarrow F m 3 m$ (spinel $\rightarrow$ NiO-type) transition. Using solid-state NMR spectroscopy, Leifer et al. [70] monitored the electrochemical properties of NCA cathode cycled in different voltage windows. When charged to lower voltage, a more complete lithium intercalation was achieved upon discharge due to the return of the environments of $\mathrm{Li}^{+}$and $\mathrm{Al}^{3+}$ in their initial configuration. These results illustrate that the capacity of this material is heavily dependent on the stability of its lamellar structure. Indeed, the $\mathrm{Al}^{3+}$ ions in NCA travel easily into the lithium layer [71], which prevents the material from collapsing into a $\mathrm{NaCl}$ phase [72]. The drawback, however, is that $\mathrm{Al}^{3+}$ ions also accelerate the spinel transformation [73]. Using transmission electron microscopy and electron diffraction, Zhang et al. investigated the structure evolution induced by the layered $\rightarrow$ spinel phase transformation at the atomic scale [74]. They considered NCA cathode particles charged to $4.7 \mathrm{~V}$ and observed the formation of a core-shell structure generated by the layered $\rightarrow$ spinel phase transformation. The layered $\rightarrow$ spinel phase transformation issues from the migration of transition metal ions from the $3 a$ layered sites to the $4 d$ spinel sites. This migration follows a 5-step pathway proposed by Guilmard et al. [75] and analyzed by Kim et al. [76]. The intermediate spinel phase is nucleated first; then spinel domains are formed, which grow up to the formation of the complete spinel structure. Simultaneous measurements including both the structural changes and the kinetic process revealed that such structural changes are accompanied with high kinetic barriers for Li-ion extraction [77]. Recently, X-ray coupled scanning tunneling microscopy measurements revealed that the nickel ions are predominantly $\mathrm{Ni}^{\mathrm{II}}$ in the first atomic layer and mixtures of $\mathrm{Ni}^{\mathrm{II}}$ with $\mathrm{Ni}{ }^{\mathrm{III}} / \mathrm{Ni}^{i \mathrm{~V}}$ already appearing $1.5 \mathrm{~nm}$ into the NCA particle. These results reveal the interplay between irreversible 
surface transformations and the bulk reactions [78]. One of the causes for the short cycle life is the release of $\mathrm{Ni}^{2+}$ ions from the $\mathrm{LiNi}_{0.8} \mathrm{Co}_{0.15} \mathrm{Al}_{0.05} \mathrm{O}_{2}$ cathode and the formation of Ni-metal particles at the surface of the graphite anode [79]. Therefore, this material, as any active cathode element, requires the coating of the nanoparticles with a layer to protect them from side reactions with the electrolyte, prevent the loss of oxygen, avoid the dissolution of the transition metal ions in the electrolyte, and stabilize the surface layer [80].

\subsection{Stability Improvement}

\subsubsection{Coating NCA}

One of the first coating materials explored for NCA is carbon [81]. Many efforts have been made since then to explore different coatings. Fluorine has been used under different forms to modify the surface of NCA. Since it is more electronegative than oxygen, fluorine can substitute to oxygen and generate stronger metal-fluorine bonds, which not only enhances the stability of the lattice, but also protects the cathode material from HF or nitrogen attacks [82]. Surface-fluorinated $\mathrm{LiNi}_{0.80} \mathrm{Co}_{0.15} \mathrm{Al}_{0.05} \mathrm{O}_{2}$ delivered a capacity of $220 \mathrm{mAh} \mathrm{g}{ }^{-1}$ with capacity retention of $93.7 \%$ after 80 cycles at $0.1 \mathrm{C}$, owing to the partial replacement of the metal-oxygen bond by the stronger metal-fluorine bond that stabilized the structure [83]. A dry and low-temperature fluorination (350 ${ }^{\circ} \mathrm{C}$ ) method was proposed by Zhao et al. [84]. The sample fluorinated with $1 \mathrm{~mol} \% \mathrm{~F}$ exhibited a capacity retention of $93.9 \%$ after 100 cycles at $1 \mathrm{C}$, against $86.2 \%$ for the pristine sample. It was argued that the fluorination generates amorphous $\mathrm{LiF}$ coating layer on the particle surface, thus restraining the diffusion of metal ions conveyed in the electrolyte. $\mathrm{AlF}_{3}$-coating was proposed by Lee et al. [6]. More recently, electrochemical and thermal properties of NCA were also improved by coating with $\mathrm{FeF}_{3}$ [85]. The $\mathrm{FeF}_{3}$-coated $\mathrm{NCA}$ cathode delivered a capacity of $182.2 \mathrm{mAh} \mathrm{g}^{-1}$ at $1 \mathrm{C}$, which decreased to $105.4 \mathrm{mAh} \mathrm{g}^{-1}$ after 100 cycles (corresponding to the retention of $57.8 \%$ ). The fluorine was also associated to Zr. The capacity retention of Zr and F codoped NCA was raised to $90.5 \%$ after 200 cycles at $1 \mathrm{C}$ [86] (see Figures 3 and 4). $\mathrm{MgF}_{2}$-coated NCA delivers a capacity that is smaller than that of pristine NCA at low C-rate, but the rate capability is better [87].

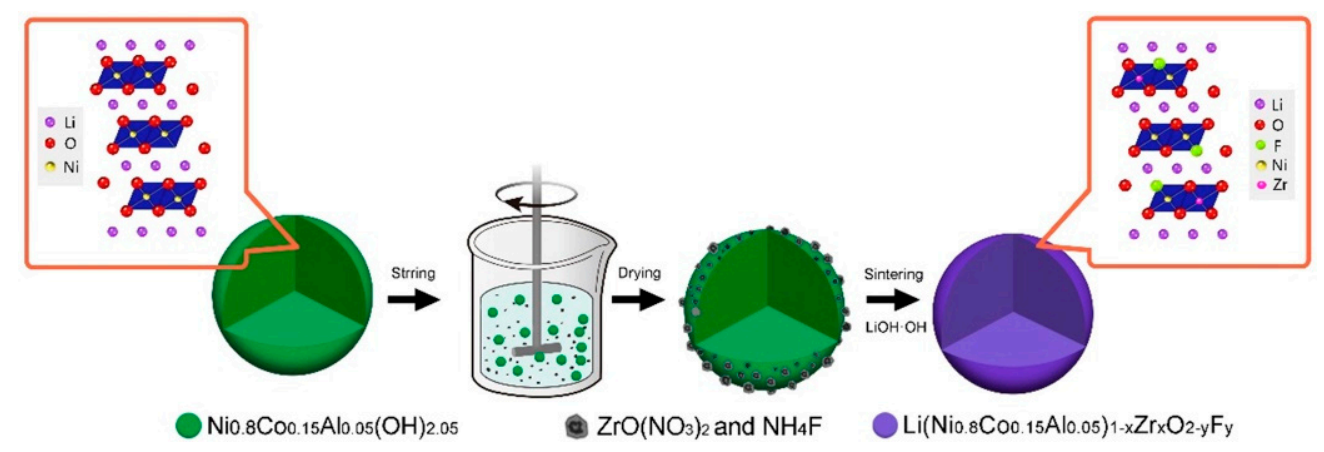

Figure 3. Synthesis schematic diagram of $\mathrm{Li}\left(\mathrm{Ni}_{0.80} \mathrm{Co}_{0.15} \mathrm{Al}_{0.05}\right)_{1-\mathrm{x}} \mathrm{Zr}_{\mathrm{x}} \mathrm{O}_{2-\mathrm{y}} \mathrm{F}_{\mathrm{y}}$. Reproduced with permission from [86]. Copyright 2019 Elsevier. 

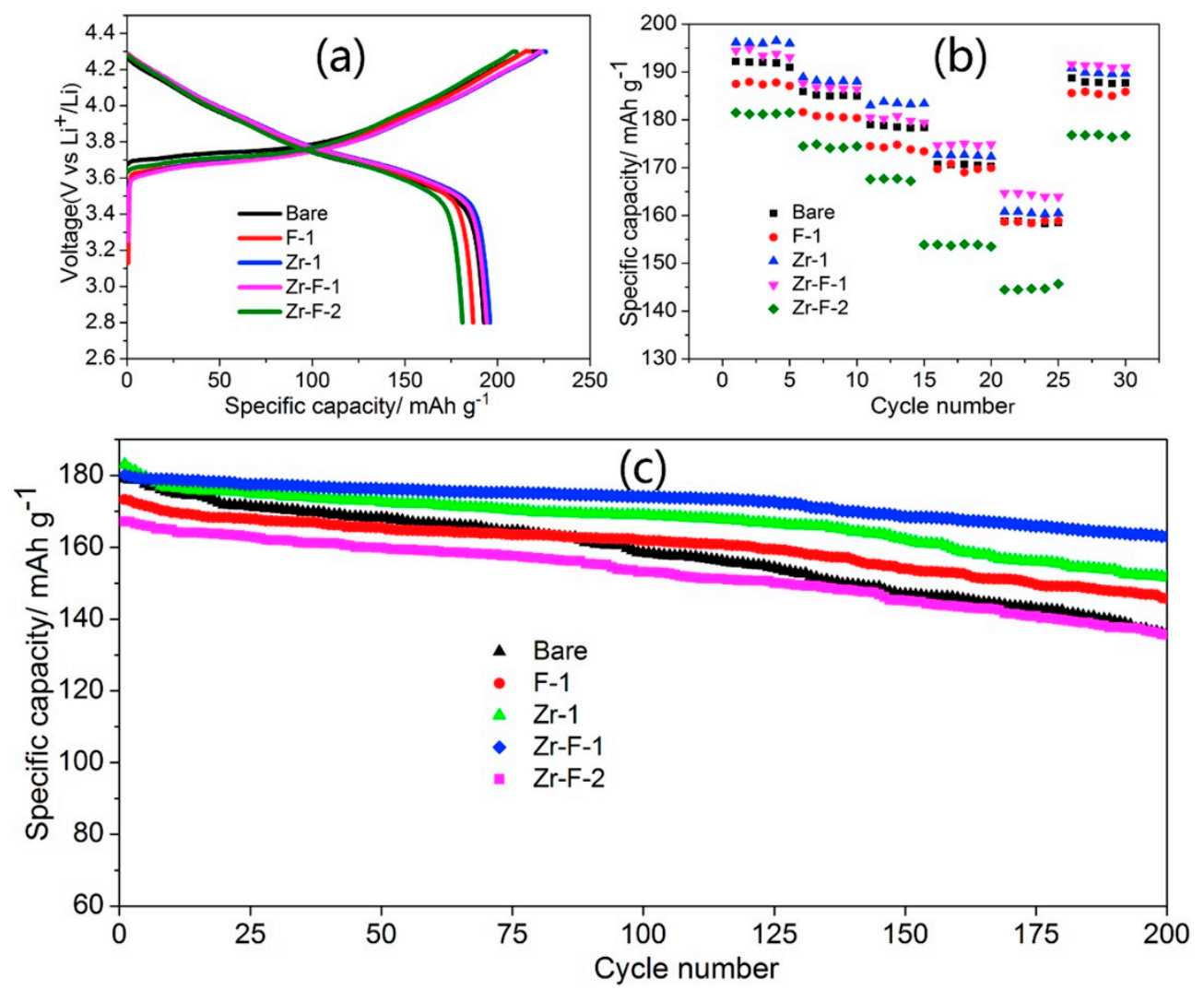

Figure 4. Electrochemical properties of $\mathrm{Li}\left(\mathrm{Ni}_{0.80} \mathrm{Co}_{0.15} \mathrm{Al}_{0.05}\right)_{1-\mathrm{x}} \mathrm{Zr}_{\mathrm{x}} \mathrm{O}_{2-\mathrm{y}} \mathrm{F}_{\mathrm{y}}(x=0, y=0.01$, labeled $\mathrm{F}-1 ; x=0.01, y=0$, labeled Zr-1; $x=0.01, y=0.01$, labeled Zr-F-1; $x=0.02, y=0.02$, labeled Zr-F-2).

(a) Initial charge-discharge curves for all samples at $0.2 \mathrm{C}$; (b) rate performance at various rates and

(c) cycling performance at 1 C. Reproduced with permission from [86]. Copyright 2019 Elsevier.

Improvement of the electrochemical performance at high temperature $\left(60^{\circ} \mathrm{C}\right)$ was also realized by coating the NCA particles with metal oxides. In particular, Cho et al. [88] used $\mathrm{SiO}_{2}$ and $\mathrm{TiO}_{2}$ dry coating to stabilize the surface of NCA nanoparticles. The $\mathrm{SiO}_{2}$ coating involved heating treatment at $700{ }^{\circ} \mathrm{C}$ in air, which might induce structural modifications. This difficulty was overcome by Zhou et al. who reported a one-step dry coating of amorphous $\mathrm{SiO}_{2}$ of an even Ni-richer material: $\mathrm{LiNi}_{0.915} \mathrm{Co}_{0.075} \mathrm{Al}_{0.01} \mathrm{O}_{2}$. Their $0.2 \mathrm{wt} . \% \mathrm{SiO}_{2}$-coated NCA delivered a capacity of $181.3 \mathrm{mAh} \mathrm{g}{ }^{-1}$ with a capacity retention of $90.7 \%$ after 50 cycles at $1 \mathrm{C}$ rate at $25^{\circ} \mathrm{C}$. At $60{ }^{\circ} \mathrm{C}$, the capacity at $1 \mathrm{C}$ was $219.2 \mathrm{mAh} \mathrm{g}^{-1}$ with a capacity retention of $66.8 \%$ after 50 cycles, against $54.3 \%$ for the pristine sample [89]. The authors then coated the same sample with $\mathrm{Zr}(\mathrm{OH})_{4}$, which delivered a capacity of $154.3 \mathrm{mAh} \mathrm{g}^{-1}$ after 100 cycles with a capacity retention of $78.1 \%$ at $1 \mathrm{C}$ rate at room temperature [90]. Actually, coating materials can be chosen among the high-k gate dielectrics that were extensively studied two decades ago to replace $\mathrm{SiO}_{2}$ gate in MOSFETs, namely $\mathrm{TiO}_{2}, \mathrm{Al}_{2} \mathrm{O}_{3}, \mathrm{Y}_{2} \mathrm{O}_{3}, \mathrm{ZrO}_{2}$ (see for instance [91] and citations therein), and indeed, all of them have been considered to coat NCA. For instance, the $\mathrm{ZrO}_{2}$ coating was effective not only to improve the electrochemical properties, but also in elevating the onset temperature of the dissociation in the charged state This improvement of the thermal stability is due to the suppression of $\mathrm{Ni}$ oxidation state changes at the surface [92]. $\mathrm{TiO}_{2}$ coating was reported by Liu et al. [93], and $\mathrm{Al}_{2} \mathrm{O}_{3}$ by Du et al. [94]. The 1 wt. $\% \mathrm{Y}_{2} \mathrm{O}_{3}$-decorated NCA exhibited a specific capacity of $181 \mathrm{mAh} \mathrm{g}^{-1}$ after 50 cycles at $0.5 \mathrm{C}$, against $134 \mathrm{mAh} \mathrm{g}^{-1}$ for the pristine one [95]. Other transition metal oxides have been also considered. When cycled between 2.8 and $4.3 \mathrm{~V}$, the capacity retention of $\mathrm{Co}_{3} \mathrm{O}_{4}$-coated NCA reached $94.7 \%$ after 100 cycles at $0.2 \mathrm{C}$, and $91.6 \%$ at $1 \mathrm{C}$ after 100 cycles [96]. Of course, the homogeneity and thickness of the coat matters and depends on the coating process. In particular, the surface modification by ALD metal-oxide coating $\left(\mathrm{TiO}_{2}, \mathrm{Al}_{2} \mathrm{O}_{3}\right.$, etc.) proved to be able to function as a mediator of $\mathrm{HF}$ attacks and protection of the 
NCM cores from corrosion [97]. However, independently of the coating process, the coating improves the electrochemical properties. In addition to the coatings above mentioned, examples include $\mathrm{ZnO}$ film deposited by sputtering [98], and coating with $\mathrm{Sb}$-doped $\mathrm{SnO}_{2}$ nanoparticles via wet-chemical route [99].

Surface modification of $\mathrm{LiNi}_{0.8} \mathrm{Co}_{0.15} \mathrm{Al}_{0.05} \mathrm{O}_{2}$ nanopowders was also obtained with various other coatings of phosphates, including $\mathrm{Ni}_{3}\left(\mathrm{PO}_{4}\right)_{2}$ [100]. $\mathrm{Li}_{3} \mathrm{PO}_{4}$ coating was obtained by exploiting the $\mathrm{H}_{3} \mathrm{PO}_{4}, \mathrm{Li}_{3} \mathrm{PO}_{4}$, and diammonium hydrogen phosphate as the precursor [101-104]. LiMnPO 4 was also proposed [105]. However, $\mathrm{LiMnPO}_{4}$ is insulating, and coating with a more conductive phosphate layer is desirable. More recently, Zhao et al. reported a one-step $\mathrm{H}_{3} \mathrm{PO}_{4}$ corrosion process to treat the NCA materials in the ethanol solution and obtain a $2 \mathrm{~nm}$-thick amorphous phosphate layer on the primary particles [106]. This electrode delivered a capacity of $153.7 \mathrm{mAh} \mathrm{g}^{-1}$ at $5 \mathrm{C}$, and $107.5 \mathrm{mAh}$ $\mathrm{g}^{-1}$ after 300 cycles at $5 \mathrm{C}$, corresponding to a retention of $90 \%$. NCA was also coated with $\mathrm{FePO}_{4}$ by Huang et al. [107], and more recently by Xia et al. who used a liquid phase process [108]. At $1 \mathrm{C}$ rate, the capacity was $160 \mathrm{mAh} \mathrm{g}^{-1}$, with a capacity retention of $85.82 \%$ for the optimized amount $2 \mathrm{wt} . \%$ $\mathrm{FePO}_{4}$. Chen et al. used an industrially viable fusion mixing method to apply Li redox-active $\mathrm{LiFePO}_{4}$ (LFP) coating. On charging to $4.5 \mathrm{~V}$ at $25^{\circ} \mathrm{C}$, the corresponding full pouch cell with graphite anode delivered a capacity of $204 \mathrm{mAh} \mathrm{g}^{-1}$ (per gram of NCA-LFP) and $82.5 \%$ capacity retention after 100 cycles. On charging to $4.2 \mathrm{~V}$ at $55^{\circ} \mathrm{C}$, NCA-LFP cathodes showed an initial capacity of $201 \mathrm{mAh} \mathrm{g}^{-1}$ and capacity retention of $95 \%$ after 150 cycles [109]. The remarkable efficiency of LFP-coating was confirmed by Huang et al. who reported that a NCA modified with $5 \mathrm{wt} . \%$ LFP has the best cycling and rate performance, with a higher capacity-retention ( $89.4 \%$ after 200 cycles, at 2 C) [110]. In this work, a simple ball-milling method was used to modify the surface of NCA materials and fill the gaps between particles, a less expensive process than sol-gel, liquid-phase, or ALD coating process, and thus more scalable for industrial development. In a different work, LFP/NCA samples were prepared by adding $20 \mathrm{wt} . \%$ LFP with different mass contents to NCA via planetary milling. The discharge capacity and capacity retention ratio were improved by $19 \%$ and $17 \%$ at $1 \mathrm{C}$, respectively, with respect to pristine NCA [111]. Pouch shaped full cells that employed $\mathrm{TiP}_{2} \mathrm{O}_{7}$-coated $\mathrm{LiNi}_{0.80} \mathrm{Co}_{0.15} \mathrm{Al}_{0.05} \mathrm{O}_{2}$ as cathode were able to perform more than 2200 cycles at $25^{\circ} \mathrm{C}$ and more than 1000 cycles at $45^{\circ} \mathrm{C}$ before the capacity retention fading to $80 \%$ [112]. The initial discharge capacity of the coated sample was 193.1 $\mathrm{mAh} \mathrm{g}^{-1}$, against $196.5 \mathrm{mAh} \mathrm{g}^{-1}$. The loss of capacity due to the $\mathrm{TiP}_{2} \mathrm{O}_{7}$ is thus negligible, while the increase of the cycle ability is remarkable.

The increase of the capacity retention $\left(169 \mathrm{mAh} \mathrm{g}^{-1}\right.$ at current density $\left.360 \mathrm{~mA} \mathrm{~g}^{-1}\right)$ with respect to that of $\mathrm{LiNi}_{0.80} \mathrm{Co}_{0.15} \mathrm{Al}_{0.05} \mathrm{O}_{2}\left(350 \mathrm{~mA} \mathrm{~g}{ }^{-1}\right.$ ) was reached with a 2 wt. $\% \mathrm{Li}_{2} \mathrm{O}-2 \mathrm{~B}_{2} \mathrm{O}_{3}$ (LBO) glass coating [113]. The cycle life was also improved, with a capacity retention of $94.2 \%$ after 100 cycles, while that of the uncoated specimen was $75.3 \%$ only. Polysiloxane with ethoxy-functional groups (EPS) was grown on NCA particles through the hydrolysis-condensation method [114]. The corresponding electrode demonstrated a capacity of $159 \mathrm{mAh} \mathrm{g}^{-1}$, with a capacity retention of $96 \%$ after 150 cycles under $1 \mathrm{C}$, to be compared with $85.82 \mathrm{wt}$.\% retention obtained earlier by the $\mathrm{FePO}_{4}$ coating mentioned above. Srur-Lavi et al. studied the influence of $\mathrm{LiAlO}_{2}$ coatings obtained by atomic layer deposition (ALD) [115]. Since this process makes possible the control of the thickness of the coat, they determined that the optimum thickness of the coating layer is $2 \mathrm{~nm}$. At C/2.5 rate in the potential range of 2.7-4.3, the retention calculated for cycle numbers $40^{\text {th }}-100^{\text {th }}$ was raised to $0.15 \mathrm{mAh} \mathrm{g}^{-1}$ per cycle. Moreover, the steady behavior of the electrode cycled with upper voltage cut-off raised at 4.4 and $4.5 \mathrm{~V}$ when the delithiation level exceeded $75-80 \%$ was improved, while charging above $4.3 \mathrm{~V}$ pristine NCA (or NCM) results in structural instability associated to oxygen loss, generation of microstrains, and rapid loss of capacity [116]. These results are in line with those of Rougier et al. who demonstrated an improvement of the electrochemical performance at $40{ }^{\circ} \mathrm{C}$ for the $\mathrm{LiAlO}_{2}$ coated sample [117]. $\mathrm{LiAlO}_{2}$ coating was also obtained by a simple process (milling $\mathrm{NCA}$ with $\mathrm{Al}\left(\mathrm{NO}_{3}\right)_{3} \cdot 9 \mathrm{H}_{2} \mathrm{O}$ followed by a heating treatment) [118]. The capacity retention after 100 cycles at $1 \mathrm{C}$ was raised to $94.67 \%$. The discharge capacity at $8 \mathrm{C}$ was $139.8 \mathrm{mAh} \mathrm{g}^{-1}$. Kwak et al. proposed $\mathrm{Li}_{2} \mathrm{MoO}_{4}$ as the coating 
material in a sulfide electrolyte. Such an electrolyte is known to be very attractive for all-solid-state cells, but it was not possible so far to use it with oxide cathode materials because of the side reactions. The $1 \mathrm{wt} . \% \mathrm{Li}_{2} \mathrm{MoO}_{4}$ coated electrode with this electrolyte showed a capacity of $\approx 167 \mathrm{mAh} \cdot \mathrm{g}^{-1}$ at the current density of $8.5 \mathrm{~mA} \cdot \mathrm{g}^{-1}$ and $143 \mathrm{mAh} \cdot \mathrm{g}^{-1}$ at $85 \mathrm{~mA} \cdot \mathrm{g}^{-1}$. Unfortunately, the cycle ability was tested on 20 cycles only [119]. $\mathrm{Li}_{2} \mathrm{TiO}_{3}$-coating of NCA improves the capacity retention, especially at high temperature, as the capacity retention after 200 cycles at $60^{\circ} \mathrm{C}$ at a rate of $1 \mathrm{C}$ was raised to $91.32 \%$ [120]. At room temperature, the uniform $4 \mathrm{~nm}$ thick $\mathrm{Li}_{2} \mathrm{TiO}_{3}$-coating capacity retention to 93.5\% after 200 cycles at $0.5 \mathrm{C}$ [121]. $\mathrm{LiTiO}_{2}$-coated $\mathrm{LiNi}_{0.815} \mathrm{Co}_{0.15} \mathrm{Al}_{0.035} \mathrm{O}_{2}$ was synthesized through in situ hydrolysis-lithiation [122]. At $1 \mathrm{C}$, the discharge capacity was $164.1 \mathrm{mAh} \mathrm{g}^{-1}$, and the capacity retention after 100 cycles was $90.8 \%$. The improvement is even more important at high rate: at $10 \mathrm{C}$, the capacity was still $157.6 \mathrm{mAh} \mathrm{g}^{-1}$. To improve the conductivity, and thus the rate capability, NCA has been coated with graphene nanodots with the size of $5 \mathrm{~nm}$ [123]. With $5 \mathrm{wt} . \%$ coating, the capacity delivered was raised to $150 \mathrm{mAh} \mathrm{g}^{-1}$ at $5 \mathrm{C}$. For comparison, three-dimensional NCA/graphene cathode synthesized by template self-assembly exhibited a reversible capacity of $153.6 \mathrm{mAh} \mathrm{g}^{-1}$ with retention of $82.1 \%$ after 100 cycles at $5 \mathrm{C}$ discharged rate [124].

The coating materials reported above are lithium-ion conductors, except antimony-doped tin oxide coating [99], and graphene nanodots [122]. Recently, dual-conductive coating consisting of electronically conductive antimony-doped tin oxide and ionically conductive $\mathrm{Li}_{2} \mathrm{TiO}_{3}$ was applied to NCA. As expected, the rate capability was improved, with a capacity of $153 \mathrm{mAh} \mathrm{g}^{-1}$ delivered at $5 \mathrm{C}$. In addition, high capacity retention of $88.56 \%$ at $1 \mathrm{C}$-rate and $60{ }^{\circ} \mathrm{C}$ after 200 cycles was demonstrated [125].

Electrochemical properties of selected $\mathrm{LiNi}_{0.80} \mathrm{Co}_{0.15} \mathrm{Al}_{0.05} \mathrm{O}_{2}$ cathode materials are reported in Table 1 , illustrating the dependence on the synthesis route, morphology of the particles, and coating, including selected results [126-131].

Table 1. Electrochemical properties of selected uncoated and coated $\mathrm{LiNi}_{0.80} \mathrm{Co}_{0.15} \mathrm{Al}_{0.05} \mathrm{O}_{2}$ cathode materials $\left(C R=\right.$ capacity retention; $S S A=$ specific surface area; $\mathrm{LATP}=\mathrm{Li}_{1.3} \mathrm{Al}_{0.3} \mathrm{Ti}_{1.7}\left(\mathrm{PO}_{4}\right)_{3}$ fast ion conductor).

\begin{tabular}{|c|c|c|c|}
\hline Synthesis Method & Characteristics & $\begin{array}{l}\text { Electrochemical } \\
\text { Performance }\end{array}$ & Ref. \\
\hline $\begin{array}{c}\text { Solid-state reaction } \\
\text { sintered at } 720{ }^{\circ} \mathrm{C} \text { for } 28 \mathrm{~h}\end{array}$ & Microspheres & $\begin{array}{c}180 \mathrm{mAh} \mathrm{g}^{-1} \text { at } 0.2 \mathrm{C} ; \mathrm{CR} \text { of } \\
87 \% \text { after } 76 \text { cycles at } 1 \mathrm{C}\end{array}$ & [126] \\
\hline $\begin{array}{l}\text { Two-step coprecipitation } \\
\text { sintering in } \mathrm{O}_{2}\end{array}$ & $\begin{array}{c}\text { Microrods, } \\
\text { SSA of } 0.5 \mathrm{~m}^{2} \mathrm{~g}^{-1}\end{array}$ & $\begin{array}{c}218 \mathrm{mAh} \mathrm{g}^{-1} \text { at } 0.1 \mathrm{C} ; \mathrm{CR} \text { of } \\
93 \% \text { after } 100 \text { cycles at } 1 \mathrm{C} \text { in } \\
\text { range } 2.7-4.3 \mathrm{~V}\end{array}$ & [127] \\
\hline $\begin{array}{l}\text { Coprecipitation with } \\
\text { 5-sulfosalicylic acid as } \\
\text { chelating agent }\end{array}$ & $\begin{array}{l}\text { Secondary spherical } \\
\text { particle } 8 \mu \mathrm{m} \text { dia. }\end{array}$ & $\begin{array}{l}203 \mathrm{mAh} \mathrm{g}^{-1} \text { at } 0.1 \mathrm{C} ; \mathrm{CR} \text { of } \\
93.3 \% \text { after } 200 \text { cycles at } 1 \mathrm{C} \\
\text { in range } 3.0-4.3 \mathrm{~V}\end{array}$ & [128] \\
\hline $\begin{array}{c}\text { Coprecipitation } \\
\text { heated at } 750{ }^{\circ} \mathrm{C} \text { under } \mathrm{O}_{2} \\
\text { stream }\end{array}$ & $\begin{array}{l}0.5-1.5 \mu \mathrm{m} \text { particle size } \\
\text { agglomerates of } 20 \mu \mathrm{m} \\
0.23 \% \text { cation mixing }\end{array}$ & $\begin{array}{c}177 \mathrm{mAh} \mathrm{g}^{-1} \text { at } 0.1 \mathrm{C} ; \mathrm{CR} \text { of } \\
82 \% \text { after } 500 \text { cycles at } 2 \mathrm{C} \\
\text { rate in range } 3.0-4.1 \mathrm{~V}\end{array}$ & [129] \\
\hline $\begin{array}{l}\text { Coprecipitation } \\
\text { sintered at } 750{ }^{\circ} \mathrm{C}\end{array}$ & $\begin{array}{l}\text { 400-600 nm particle size } \\
\text { polyhedral shape }\end{array}$ & $\begin{array}{l}200 \mathrm{mAh}^{-1} \text { at } 0.2 \mathrm{C} ; 92 \% \\
\mathrm{CR} \text { after } 60 \text { cycles at } 1 \mathrm{C}\end{array}$ & [130] \\
\hline $\begin{array}{l}\text { Ball milling with LATP } \\
\text { Sintered at } 750^{\circ} \mathrm{C} \text { in } \mathrm{O}_{2}\end{array}$ & $\begin{array}{l}10 \mu \mathrm{m} \text { spherical particle } \\
200 \mathrm{~nm} \text { thick coating }\end{array}$ & $\begin{array}{c}180 \mathrm{mAh} \mathrm{g}^{-1} \text { at } 0.1 \mathrm{C} ; \mathrm{CR} \text { of } \\
88 \% \text { after } 100 \text { cycles at } 2 \mathrm{C} \\
\text { rate in range } 2.8-4.3 \mathrm{~V}\end{array}$ & [131] \\
\hline
\end{tabular}


Table 1. Cont.

\begin{tabular}{|c|c|c|c|}
\hline Synthesis Method & Characteristics & $\begin{array}{l}\text { Electrochemical } \\
\text { Performance }\end{array}$ & Ref. \\
\hline $\begin{array}{l}\text { Coprecipitation, sintered at } \\
\text { various } \mathrm{O}_{2} \text { pressures } \\
\text { optimized for } 0.1 \mathrm{MPa}\end{array}$ & Sphere-like $15 \mu \mathrm{m}$ dia. & $\begin{array}{c}166 \mathrm{mAh}^{-1} \text { at } 0.1 \mathrm{C} ; \mathrm{CR} \text { of } \\
87 \% \text { after } 100 \text { cycles at } 1 \mathrm{C} \\
\text { rate in range } 2.8-4.3 \mathrm{~V}\end{array}$ & [25] \\
\hline $\begin{array}{l}\text { Polysiloxane coating } \\
\text { Hydrolysis condensation }\end{array}$ & $\begin{array}{l}\text { Spherical agglomerates } \\
\qquad 20 \mu \mathrm{m} \text { dia. }\end{array}$ & $\begin{array}{c}184 \mathrm{mAh}^{-1} \text { at } 0.1 \mathrm{C} ; \mathrm{CR} \text { of } \\
96 \% \text { after } 150 \text { cycles at } 1 \mathrm{C} \\
\text { rate in range } 2.8-4.3 \mathrm{~V}\end{array}$ & [114] \\
\hline $\begin{array}{c}\mathrm{Li}_{2} \mathrm{O}-2 \mathrm{~B}_{2} \mathrm{O}_{3} \text { coating by a } \\
\text { solution method }\end{array}$ & Commercial LCA & $\begin{array}{c}169 \mathrm{~mA} \mathrm{~g}^{-1} \text { at } 360 \mathrm{~mA} \mathrm{~g}^{-1} \\
\mathrm{CR} \text { of } 94.2 \% \text { after } 100 \text { cycles } \\
\text { in the range } 3.0-4.3 \mathrm{~V}\end{array}$ & [113] \\
\hline $\mathrm{LiAlO}_{2}$ coating by ALD & Commercial LCA & $\begin{array}{l}198 \mathrm{mAh} \mathrm{g}^{-1} \text { at C/5 in the } \\
\text { range } 2.7-4.5 \mathrm{~V} ; \mathrm{CR} 91 \% \\
\text { between } 40 \text { th and } 100 \text { th cycle }\end{array}$ & [115] \\
\hline $\mathrm{LiAlO}_{2}$ coating by milling & $\begin{array}{l}\text { Spherical agglomerates } \\
\qquad 20 \mu \mathrm{m} \text { dia. }\end{array}$ & $\begin{array}{c}172.3 \mathrm{mAh} \mathrm{g}^{-1} \text { at } 1 \mathrm{C} ; \mathrm{CR} \text { of } \\
94.67 \% \text { after } 100 \text { cycles at } 1 \mathrm{C} \\
\text { in the range } 3.0-4.3 \mathrm{~V}\end{array}$ & [118] \\
\hline $\begin{array}{l}\mathrm{Li}_{2} \mathrm{TiO}_{3} \text { coating by } \\
\text { near-equilibrium } \\
\text { deposition }\end{array}$ & $\begin{array}{l}\text { Spherical agglomerates } \\
\qquad 6-8 \mu \mathrm{m} \text { dia. }\end{array}$ & $\begin{array}{c}187.5 \mathrm{mAh}^{-1} \text { at } 0.5 \mathrm{C} ; \mathrm{CR} \text { of } \\
93.5 \% \text { after } 200 \text { cycles at } 0.5 \\
\mathrm{C} \text { in the range } 2.8-4.3 \mathrm{~V}\end{array}$ & [121] \\
\hline $\begin{array}{l}\mathrm{LiTiO}_{2} \text { coating by } \\
\text { hydrolysis }\end{array}$ & $\begin{array}{l}\text { Spherical agglomerates } \\
\text { 3-15 } \mu \mathrm{m} \text { dia. }\end{array}$ & $\begin{array}{l}164.1 \mathrm{mAh} \mathrm{g}^{-1} \text { at } 1 \mathrm{C} ; \mathrm{CR} \text { of } \\
90.8 \% \text { after } 100 \text { cycles at } 1 \mathrm{C} \\
\text { in the range } 2.8-4.3 \mathrm{~V}\end{array}$ & [122] \\
\hline $\begin{array}{l}\text { Dual coating Sb-doped } \\
\qquad \mathrm{SnO}_{2} \text { and } \mathrm{Li}_{2} \mathrm{TiO}_{3}\end{array}$ & $\begin{array}{l}\text { Spherical agglomerates } \\
10 \mu \mathrm{m} \text { dia. }\end{array}$ & $\begin{array}{l}153 \mathrm{mAh} \mathrm{g}^{-1} \text { at } 5 \mathrm{C} ; \mathrm{CR} \text { of } \\
88.56 \% \text { after } 200 \text { cycles at } 1 \mathrm{C} \\
\text { at } 60^{\circ} \mathrm{C} \text { in the range } 3.4 .3 \mathrm{~V}\end{array}$ & [125] \\
\hline
\end{tabular}

One decade ago, a core-shell structured $\mathrm{Li}\left(\mathrm{Ni}_{0.80} \mathrm{Co}_{0.15} \mathrm{Al}_{0.05}\right)_{0.8}\left(\mathrm{Ni}_{0.5} \mathrm{Mn}_{0.5}\right)_{0.2} \mathrm{O}_{2}$ was experimented [132,133]. The difference between the coating and the core-shell structure lies in the thickness. The thickness of the coating layer is usually few nanometers. The core-shell structure refers to a situation where the thickness of the shell is in the range of submicron to micron order. The results at that time showed an improvement of the rate capability and capacity with respect to pristine NCA, but the cycle life was poor, because the change of volume and lattice distortion during cycling caused the disintegration of the structure. Other works followed in particular with NCM, which will be reviewed in a following section.

\subsubsection{Doping NCA}

Another strategy used to improve the cycle ability of NCA is the doping. While the coating has little effect on the stability of the bulk material and acts by protecting the surface layer against side reactions with the electrolyte and loss of oxygen during cycling, the doping stabilizes the bulk structure. In particular, $\mathrm{K}^{+}$doping is efficient for this purpose [134], because $\mathrm{K}^{+}$occupies the $\mathrm{Li}^{+}$ site and its larger radius prevents the contraction of the lattice associated to the formation of highly resistive $\mathrm{NiO}$ at the end of charge, when $\mathrm{Ni}^{4+}$ can be spontaneously reduced to $\mathrm{Ni}^{2+}$ tending to migrate from transition-metal layer to the tri-vacancies in lithium layer [49]. $\mathrm{Li}_{0.99} \mathrm{~K}_{0.01} \mathrm{Ni}_{0.8} \mathrm{Co}_{0.15} \mathrm{Al}_{0.05} \mathrm{O}_{2}$ delivered a capacity of $217 \mathrm{mAh} \mathrm{g}^{-1}$ at $0.1 \mathrm{C}$. At $1 \mathrm{C}$, the capacity maintained at $200 \mathrm{mAh} \mathrm{g}^{-1}$, with a capacity retention of $87.4 \%$ after 150 cycles. The $\mathrm{Cr}$ doping has two advantages: (i) the redox reactions of $\mathrm{Cr}^{3+} / \mathrm{Cr}^{6+}$ can enhance the capacity of NCA [135]; (ii) this doping can promote the activation of $\mathrm{Li}_{2} \mathrm{MnO}_{3}$ [136]. On another hand, $\mathrm{Cu}$ and/or Fe-doping decreases the capacity because $\mathrm{Cu}$ and Fe are not electrochemically active in the voltage range $2.8-4.3 \mathrm{~V}$, but this doping improved the cycle ability and rate capability [137]. 
The capacity retention of Zr-doped NCA after 50 cycles at $0.5 \mathrm{C}$ in the range 2.8-4.3 V was raised to $92 \%$, against $79 \%$ for the pristine sample [138]. The $1 \mathrm{~mol} \%$ Ti-doping of NCA proved to be efficient in maintaining the integrity of the structure and preventing the surface from deterioration even at high voltage. This doped sample delivered a discharge capacity of $179.6 \mathrm{mAh} \mathrm{g}^{-1}$ after 200 cycles at $1 \mathrm{C}$ in the range 3.0-4.5 V, with a capacity retention of $97.4 \%$, in comparison with $167.3 \mathrm{mAh} \mathrm{g}^{-1}$ and $89.2 \%$, respectively, for pristine $\mathrm{LiNi}_{0.80} \mathrm{Co}_{0.15} \mathrm{Al}_{0.05} \mathrm{O}_{2}$ [139]. Moreover, a very good cycle stability was observed for this doped sample under a cutoff voltage up to $4.7 \mathrm{~V}$, since the capacity remained stable at $170 \mathrm{mAh} \mathrm{g}^{-1}$ between the $30^{\text {th }}$ and the $100^{\text {th }}$ cycle at $0.1 \mathrm{C}\left(20 \mathrm{~mA} \mathrm{~g}^{-1}\right)$ between 3.0 and $4.7 \mathrm{~V}$ at room temperature [140]. Surface Te-doping was also efficient to improve the reversibility of the $\mathrm{H} 2 \leftrightarrow \mathrm{H} 3$ transition thanks to the suppression of the lattice distortion along the c-axis by strong $\mathrm{Te}-\mathrm{O}$ bonds, allowing for the use of an upper voltage at $4.5 \mathrm{~V}$. When cycled in the voltage range $2.7-4.5 \mathrm{~V}$ at $1 \mathrm{C}$, the $\mathrm{LiNi}_{0.88} \mathrm{Co}_{0.09} \mathrm{Al}_{0.03} \mathrm{O}_{2}$ doped with $1 \mathrm{wt} . \%$ Te delivered a capacity of $166.9 \mathrm{mAh} \mathrm{g}^{-1}$ capacity after 100 cycles, corresponding to $81.4 \%$ retention. At $1 \mathrm{C}$ in the usual voltage range $2.7-4.3 \mathrm{~V}$, the capacity retention was $89.3 \%$ after 100 cycles [141].

Since Al doping is intended to increase the structural stability, Liang et al. fabricated a quasi-concentration-gradient $\mathrm{LiNi}_{0.80} \mathrm{Co}_{0.15} \mathrm{Al}_{0.05} \mathrm{O}_{2}$ cathode material with a high $\mathrm{Al}$ concentration that was used as a shell of composition $\mathrm{LiNi}_{0.6} \mathrm{Co}_{0.15} \mathrm{Al}_{0.25} \mathrm{O}_{2}$ and a core material $\mathrm{LiNi}_{0.80} \mathrm{Co}_{0.15} \mathrm{O}_{2}$ [142] Thus modified, this material demonstrated a capacity of $198.1 \mathrm{mAh} \mathrm{g}^{-1}$ at $20 \mathrm{~mA} \mathrm{~g}^{-1}$ with $87.8 \%$ retention at $0.2 \mathrm{C}$ after 200 cycles; $70.9 \%$ at $1 \mathrm{C}$ after 500 cycles. Tian et al. investigated the influence of the surface aluminum concentration on the structure and electrochemical performance of the core-shell NCA material. They demonstrated that Al-doping shrinks the interatomic distance in the transition metal layer but expand the transition metal layers, which facilitates the migration of lithium-ions. They also reported that the $\mathrm{Li}\left[\left(\mathrm{Ni}_{0.85} \mathrm{Co}_{0.15}\right)_{2 / 3}\left(\mathrm{Ni}_{0.7} \mathrm{Co}_{0.15} \mathrm{Al}_{0.15}\right)_{1 / 3}\right] \mathrm{O}_{2}$ electrode delivered the discharge capacity of $182.6 \mathrm{mAh} \mathrm{g}^{-1}$ with the capacity retention of $91.2 \%$ at $0.2 \mathrm{C}$ after 260 cycles [143]. Natarajan et al. exploited the high diffusion of nano- $\mathrm{Al}(\mathrm{OH})_{3}$ driven by the concentration gradient of $\mathrm{Al}$ across the hierarchical hydroxide structure and synthesized $\mathrm{LiNi}_{0.8} \mathrm{Co}_{0.135} \mathrm{Al}_{0.065} \mathrm{O}_{2}$ with reduced $\mathrm{Ni}$ and increased $\mathrm{Al}$ at the surface. The capacity retention in the full cell configuration was increased to $91.5 \%$ after 150 cycles when cycled between 3 and $4.3 \mathrm{~V}$ at $1 \mathrm{C}$. The capacity loss was reduced to $1 \%$ even after 500 cycles by limiting the upper cutoff voltage to 4.2 V [144] (see Figures 5 and 6).

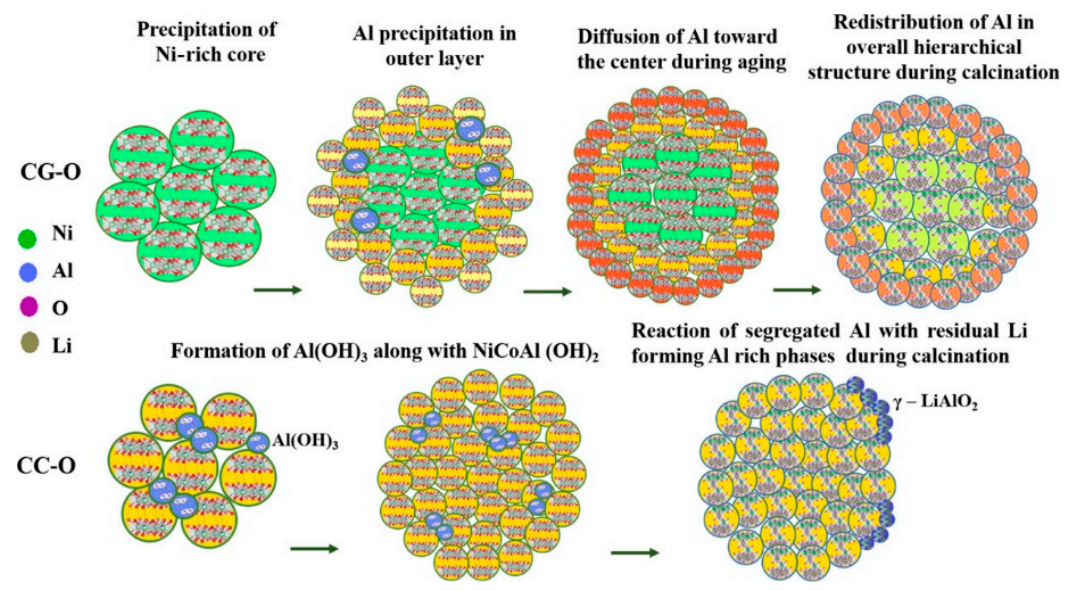

Figure 5. Schematic representation of various stages in the formation of $\mathrm{LiNi}_{0.8} \mathrm{Co}_{0.135} \mathrm{Al}_{0.065} \mathrm{O}_{2}$ particles CC-O (compositionally constant) and CG-O (compositionally constant core with the graded surface) during the precipitation and high-temperature calcination. Reproduced with permission from [144]. Copyright 2020 American Chemical Society. 

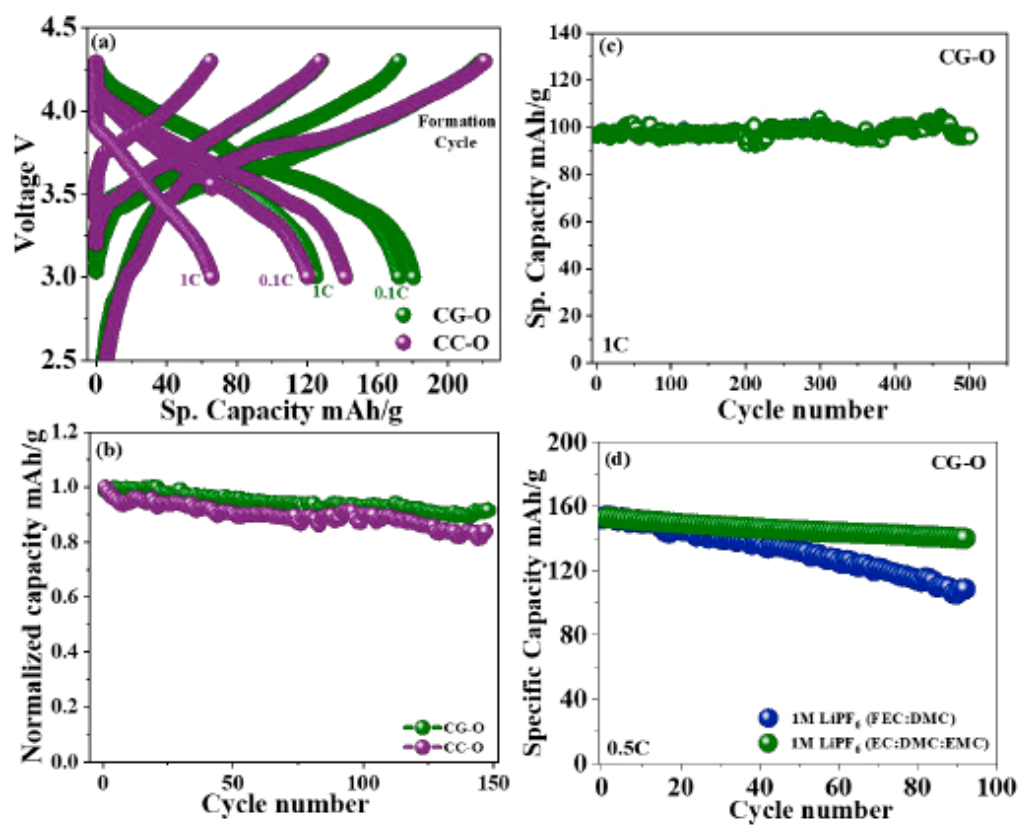

Figure 6. (a) Charge-discharge plateau of formation cycle, at $0.1 \mathrm{C}$ rate and $1 \mathrm{C}$ in full cells with CG-O cathode (see Figure 5) and graphite anode in the voltage range of 3.0-4.3V. (b) Normalized full cell cyclic stability $1 \mathrm{C}$ rate in the voltage range of 3.0-4.3V of CC-O and CG-O. (c) Cyclic stability of CG-O in the voltage range of 3.0-4.2V. (d) Comparison of cyclic stability of CG-O with different electrolytes. Reproduced with permission from [144]. Copyright 2020 American Chemical Society.

$\mathrm{Fe}$ doping improved the cycle ability of NCA owing to the effect of the $\mathrm{FeO}_{6}$ octahedron on the edge-shared $\mathrm{NiO}_{6}$ octahedra via enhanced electron localization. In particular, the $\mathrm{LiNi}_{0.80} \mathrm{Co}_{0.075} \mathrm{Fe}_{0.075} \mathrm{Al}_{0.05} \mathrm{O}_{2}$ material demonstrated a capacity retention of $88.4 \%$ at $1 \mathrm{C}$ after 350 cycles [145]. In Na-doped NCA, Na occupies the lithium slab, leading to a small decrease of capacity but large improvement of the cycle ability and rate capability. The $\mathrm{Li}_{0.99} \mathrm{Na}_{0.01} \mathrm{Ni}_{0.8} \mathrm{Co}_{0.15} \mathrm{Al}_{0.05} \mathrm{O}_{2}$ exhibited a capacity of $184.6 \mathrm{mAh} \mathrm{g}^{-1}$ at $0.1 \mathrm{C}$, with retention of $90.71 \%$ after 200 cycles when cycled at $1 \mathrm{C}$ in the voltage range $2.8-4.3 \mathrm{~V}$ [146].

Gui et al. reported a spray-drying doping with liquid polyacrylonitrile (LPAN). After the carbonization of LPAN, the $\mathrm{C}$ atoms replace part of $\mathrm{O}$ atoms, effectively forming a new compound with cation mixing reduced to $2.7 \%$ [147]. As a result, the initial discharge capacity was raised to $227.9 \mathrm{mAhg}^{-1}$ at $0.1 \mathrm{C}$, which is $26.6 \%$ higher than that of the pristine sample, and the capacity retention rate was found to be $93.59 \%$ after 200 cycles.

Mn could be uniformly incorporated into the structure of NCA when the content of Mn is less than $3 \mathrm{wt} . \%$ [148]. The size of the primary grains varies from about $800 \mathrm{~nm}$ for the pristine NCA, to about $400 \mathrm{~nm}$ in the NCA doped with $3 \mathrm{wt} . \% \mathrm{Mn}$ (called NMCA1 sample). This is an advantage to reduce the microcracks and improve the rate capability, as mentioned in the introduction. At a current density of $0.1 \mathrm{C}\left(1 \mathrm{C}=180 \mathrm{~mA} \mathrm{~g}^{-1}\right)$ and in a voltage range of $2.8-4.3 \mathrm{~V}$, the NMCA1 delivered initial charge/discharge capacities of $213.3 / 169.7 \mathrm{mAh} \mathrm{g}^{-1}$ at $0.1 \mathrm{C}$. At $2 \mathrm{C}$, the capacity retention over 500 cycles was $89 \%$ (from 174.0 to $154.4 \mathrm{mAh} \mathrm{g}^{-1}$ ), and remained at $81 \%$ after 900 cycles. The authors attributed this remarkable result to the infusion of the Mn-containing species into the sphere along crystal boundaries and microvoids at high temperature of the primary grains resulting in the accommodation of the internal strain and few microcracks formed inside the MNCA1 spheres. The electrochemical properties of LCA with various dopants are reported in Table 2. 
Table 2. Electrochemical properties of selected doped $\mathrm{LiNi}_{0.80} \mathrm{Co}_{0.15} \mathrm{Al}_{0.05} \mathrm{O}_{2}$ cathode materials $(\mathrm{CR}=$ capacity retention).

\begin{tabular}{|c|c|c|}
\hline Dopant & Electrochemical Properties & \\
\hline K & $\begin{array}{c}217 \mathrm{mAh} \mathrm{g}^{-1} \text { at } 0.1 \mathrm{C} ; \mathrm{CR} \text { of } 87.4 \% \text { after } 150 \text { cycles } \\
\text { at } 1 \mathrm{C}(2.8-4.6 \mathrm{~V}) .\end{array}$ & [134] \\
\hline $\mathrm{Zr}$ & $\begin{array}{l}133.6 \mathrm{mAh} \mathrm{g}^{-1} \text { after } 100 \text { cycles at } 250 \mathrm{~mA} \mathrm{~g}^{-1} \\
\qquad(2.5-4.6 \mathrm{~V})\end{array}$ & [135] \\
\hline $\mathrm{Fe}$ & $\begin{array}{c}138.9 \mathrm{mAh} \mathrm{g}^{-1} \text { at } 1 \mathrm{C} \text { with } \mathrm{CR} \text { of } 88.4 \% \text { at } 1 \mathrm{C} \\
\text { after } 350 \text { cycles }(2.8-4.3 \mathrm{~V})\end{array}$ & [145] \\
\hline $\mathrm{Cu}$ and $\mathrm{Fe}$ & $\begin{array}{l}\text { Initial discharge } 143 \mathrm{mAh}^{-1} \text { at } 10 \mathrm{C} ; 168 \mathrm{mAh} \\
\mathrm{g}^{-1} \text { after } 100 \text { cycles at } 1 \mathrm{C}(2.8-4.3 \mathrm{~V})\end{array}$ & [137] \\
\hline $\mathrm{Ti}$ & $\begin{array}{c}179.6 \mathrm{mAh} \mathrm{g}^{-1} \text { after } 200 \text { cycles at } 1 \mathrm{C} ; \mathrm{CR} \text { at } 97.4 \% \\
(3.0-4.5 \mathrm{~V})\end{array}$ & [139] \\
\hline Mn & $\begin{array}{l}174.0 \mathrm{mAh} \mathrm{g}^{-1} \text { at } 2 \mathrm{C} \text {, with } \mathrm{CR} \text { of } 81 \% \text { after } 900 \\
\text { cycles at } 2 \mathrm{C}(2.8-4.3 \mathrm{~V})\end{array}$ & [148] \\
\hline Te (1 wt.\%) & $\begin{array}{c}159.2 \mathrm{mAh} \mathrm{g}^{-1} \text { at } 10 \mathrm{C}, 205 \mathrm{mAh} \mathrm{g}^{-1} \text { at } 1 \mathrm{C} ; \mathrm{CR} \text { of } \\
81.4 \% \text { after } 100 \text { cycles at } 1 \mathrm{C}(2.7-4.5 \mathrm{~V})\end{array}$ & [141] \\
\hline $\mathrm{Na}$ & $\begin{array}{c}170.1 \mathrm{mAh} \mathrm{g}^{-1} \text { at } 1 \mathrm{C}, \mathrm{CR} \text { of } 90.7 \% \text { after } 200 \text { cycles } \\
\text { at } 1 \mathrm{C}(2.8-4.3 \mathrm{~V})\end{array}$ & [146] \\
\hline $\begin{array}{l}\text { Concentration gradient } \\
\text { of } \mathrm{Al}\end{array}$ & $\begin{array}{l}116 \mathrm{mAh} \mathrm{g}^{-1} \text { at } 10 \mathrm{C}, 214 \mathrm{mAh} \mathrm{g}^{-1} \text { at } 0.1 \mathrm{C} \\
\qquad(2.8-4.4 \mathrm{~V}) \\
\text { full cell: } 195 \mathrm{mAh} \mathrm{g}^{-1} \text { at } 1 \mathrm{C} \text { with } \mathrm{CR} \text { at } 99 \% \text { after } \\
500 \text { cycles }(3-4.2 \mathrm{~V})\end{array}$ & [144] \\
\hline $\begin{array}{l}\text { Concentration gradient } \\
\text { of } \mathrm{Al}\end{array}$ & $\begin{array}{l}198.1 \mathrm{mAh} \mathrm{g}^{-1} \text { at } 0.1 \mathrm{C} ; \mathrm{CR} \text { of } 70.9 \% \text { after } 500 \\
\text { cycles at } 1 \mathrm{C}(3-4.3 \mathrm{~V})\end{array}$ & [142] \\
\hline
\end{tabular}

Surprisingly, only few attempts have been made to improve the Li-rich layer NCA cathode using the synergetic effects of ionic doping combined with surface modification. $\mathrm{Mg}^{2+}$ surface doping and $\mathrm{Li}_{3} \mathrm{PO}_{4}$ coating were simultaneously obtained by mixing the deteriorated NCA with $\mathrm{MgHPO}_{4}$ precursor, followed by annealing at $750{ }^{\circ} \mathrm{C}$ [149]. As a result, the degree of $\mathrm{Li} / \mathrm{Ni}$ cation-mixing and the amount of surface residual lithium species were reduced. Consequently, the discharge capacities at the first cycle at room temperature at rate $2 \mathrm{C}$ was raised to $168.5 \mathrm{mAh} \mathrm{g}^{-1}$, and was maintained at $142.6 \mathrm{mAhg}^{-1}$ at the 200th cycles, corresponding to a capacity retention of $84.6 \%$. Simultaneous $\mathrm{Mg}^{2+}$ doping and $\mathrm{Al}_{2} \mathrm{O}_{3}$-coating of NCA were performed to obtain a capacity retention of $99 \%$ after 100 cycles and $95 \%$ after 250 cycles (from 178 to $168.9 \mathrm{mAh} \mathrm{g}^{-1}$ ) at $1 \mathrm{C}$ rate [150]. Another advantage linked to the $\mathrm{Mg}$ doping is the increased thermal stability, since the thermal runaway temperature of the Mg-NCA battery should exceed that of the undoped NCA battery by $15^{\circ} \mathrm{C}$. This is because the crystal structure stabilization by $\mathrm{Mg}$ substitution suppressed oxygen release and reduced the enthalpy in the trigger reaction [151]. A similar synergetic effect was obtained by simultaneous CdO coating and Cd ion doping [152]. The capacity retention in this case was $96.5 \%$ and $90.6 \%$ after 100 cycles and 200 cycles, respectively, at $1 \mathrm{C}$. At the higher current rate of $8 \mathrm{C}$, the initial capacity was $166.2 \mathrm{mAh} \mathrm{g}^{-1}$ and the capacity retention ( 100 cycles, $3.0-4.3 \mathrm{~V}$ ) was $95.2 \%$. The $\mathrm{Nd}_{2} \mathrm{AlO}_{3} \mathrm{~N}$ coating plus $\mathrm{Nd}^{3+}$ doping of NCA increased the capacity to $168 \mathrm{mAh} \mathrm{g}^{-1}$ after 200 cycles at $1 \mathrm{C}$, which amounts to a retention of 91\% [153]. This result was attributed to the larger ion radius of $\mathrm{Nb}^{3+}$ and stronger $\mathrm{Nd}-\mathrm{O}$ bond energy that enhanced the kinetics and stabilized the NCA structure. Ti-doping plus $\mathrm{Al}(\mathrm{OH})_{3}$ coating was also explored, since Ti occupies Li-ions and widens the Li layer spacing and thereby increases the lithium diffusion kinetics, while $\mathrm{Al}(\mathrm{OH})_{3}$ coating inhibits side reactions. As a result, a capacity retention of $82.2 \%$ after 100 cycles at $1 \mathrm{C}$ was demonstrated [154]. 


\subsubsection{Optimization of the Electrolyte}

All the results reported we have reported so far were obtained in cells with liquid electrolytes. Attempts were also made in the recent years to fabricate all-solid-state batteries with NCA cathodes. In particular, Liu et al. NCA cathode with a polyvinylidene fluoride (PVDF)/ $\mathrm{Li}_{6.75} \mathrm{La}_{3} \mathrm{Z}_{1.75} \mathrm{Ta}_{0.25} \mathrm{O}_{12}$ (LLZTO) composite polymer electrolyte [155]. They found that a gradient cathode with excessive addition of LLZTO on the surface enhanced the cycling performance, due to a localized cation migration region in the surface layer of NCA that suppressed the cation mixing. At $0.5 \mathrm{C}\left(100 \mathrm{~mA} \mathrm{~g}^{-1}\right)$, a capacity retention of $89 \%$ was demonstrated after 50 cycles. A gel-polymer electrolyte (GPE) obtained by in situ polymerization of pentaerythritol tetraacrylate (PETEA) in a liquid electrolyte was used to build NCA/GPE/graphite (NPG) and NCA/GPE/(graphite-Si/C) (NPGS) batteries with energy densities 225 and $228 \mathrm{Wh} \mathrm{kg}^{-1}$, respectively [156]. At $45^{\circ} \mathrm{C}$, the capacities of NPGS and NPG batteries after 280 cycles were 1.88 and $1.99 \mathrm{~A} \mathrm{~h}$, which corresponds to capacity retentions of $83.9 \%$ and $86.4 \%$, respectively. For comparison, those of the same cells with the usual liquid electrolyte instead of the GPE were only $68.9 \%$ and $75.7 \%$, respectively. This improvement of the performance shows that the GPE was efficient to form a tight and protective film on the surface of the particles, which the authors attributed to the three-dimensional framework of the GPE.

Another strategy consists in the modification of the surface by an artificial film at the cathode-electrolyte interface (CEI) owing to an appropriate electrolyte. In this spirit lithium difluoro(oxalate)borate (LiDFOB)-based electrolyte was made compatible with NCA by the employment of sulfolane (SL) as a representative sulfur-containing solvent. It actually enhanced the interfacial stability of NCA electrode [157]. The decomposition of LiDFOB on the surface of the positive electrode material contributes to forming a uniform SEI film, which subsequently reduces the dissolution of metal ions and hinders the structure transition of the material from the layered structure to spinel or rock-salt phases. Kim et al. proposed a concept fundamentally different from previously reported cathode modification. They fabricated an artificial CEI by mixing cobalt phosphate composite powder that consisted of $\mathrm{Co}_{2} \mathrm{P}_{2} \mathrm{O}_{7}$ and $\mathrm{Co}_{3}\left(\mathrm{PO}_{4}\right)_{2}$ mixed with the NCA before annealing at $700{ }^{\circ} \mathrm{C}$ under oxygen atmosphere. During this annealing process, the residual lithium-based impurities on the cathode surface were reduced. The interaction with hydrolysis by-products during the formation of the SEI led to the formation of a homogeneous $\mathrm{Li}_{x} \mathrm{PO}_{y}$ layer and transition metal ion concentration gradient, after rearrangement across the grain boundaries [158]. The $\mathrm{LiNi}_{0.84} \mathrm{Co}_{0.14} \mathrm{Al}_{0.02} \mathrm{O}_{2}$ cathode with this artificial CEI layer demonstrated a remarkable capacity retention and structural integrity. The tests were performed with the electrode loading level of $\approx 12 \mathrm{mg} \mathrm{cm}^{-2}$ and density of $\approx 3.3 \mathrm{~g} \mathrm{~cm}^{-3}$, which correspond to fabrication conditions for industrial use. At $60^{\circ} \mathrm{C}$, where the operating voltage ranged from 2.8 to $4.4 \mathrm{~V}$ (charge and discharge C-rate: 0.5 and $1 \mathrm{C}$ ), the capacity maintained at $180 \mathrm{mAh} \mathrm{g}^{-1}$ after 200 cycles. Another process using the grain boundaries was proposed by Yan et al. who demonstrated that infusing the grain boundaries of the NCA secondary particles with a solid electrolyte increases importantly the capacity retention [159]. We will see in the next section different electrolytes and additives that have been tested with NCM811.

\section{4. $\mathrm{LiNi}_{0.8} \mathrm{Co}_{0.1} \mathrm{Mn}_{0.1} \mathrm{O}_{2}(\mathrm{NCM} 811)$}

In search of high-power lithium-ion batteries, NCM compounds of various compositions have attracted a lot of attention aiming to enhance both the thermal and the structural stability in order to increase the capacity retention. Actually, the combination of $\mathrm{Ni}, \mathrm{Mn}$, and Co can provide many advantages. Figure 7 presents the composition-performance relationship of NCM oxides. As evidenced, the choice of a cathode material is a compromise between the capacity delivered by the cell and its thermal stability. In addition, lithium in excess is usually used during the synthesis, to compensate for the loss of $\mathrm{Li}$ that occurs during the sintering process. The lithium in excess in the final sample is in the form of $\mathrm{Li}_{2} \mathrm{O}$, which can easily react with $\mathrm{H}_{2} \mathrm{O}$ and $\mathrm{CO}_{2}$ in the air and consequently convert into $\mathrm{LiOH}$ and $\mathrm{Li}_{2} \mathrm{CO}_{3}$ at room temperature. The residual carbonate would decompose to $\mathrm{CO}_{2}$ in the formation (charging) process, thus leading to gas expansion and the source of other safety 
problems $[101,160,161]$. Among these layered NCM oxides, $\mathrm{LiNi}_{0.8} \mathrm{Mn}_{0.1} \mathrm{Co}_{0.1} \mathrm{O}_{2}$ has attracted special interest due to its high discharge capacity of $\approx 200 \mathrm{mAh} \mathrm{g}^{-1}$ at current rate of $0.2 \mathrm{C}$ in the voltage range 2.8-4.3 V. A silicon-graphite//NCM811 18650-type cell from Samsung-SDI exhibits a standard discharge capacity $\geq 3350 \mathrm{mAh}$ when discharged at $1 \mathrm{C}$ with the voltage limit 2.65-4.2 V. Like in the case of NCA, the upper voltage cutoff of $4.3 \mathrm{~V}$ is used to preserve the strong oxidizing property of $\mathrm{Ni}^{4}{ }_{+}$ions in the delithiated $\mathrm{Li}_{1-\mathrm{x}} \mathrm{Ni}_{0.8} \mathrm{Mn}_{0.1} \mathrm{Co}_{0.1} \mathrm{O}_{2}$ phase. At potentials greater than $4.3 \mathrm{~V}$, surface-reconstruction processes giving rise to substantial $\mathrm{CO}_{2}$ and $\mathrm{O}_{2}$ release occur, implying that surface-reconstructed layers a few nanometers thick are formed [162]. The situation is thus pretty much the same as in NCA, which is not surprising since the $\mathrm{Ni}$ content and the $\mathrm{Ni} / \mathrm{C}$ o ratio are found to govern the onset, rate, and extent of these surface-reconstruction processes.

\subsection{Synthesis}

Most of the $\mathrm{LiNi}_{0.8} \mathrm{Mn}_{0.1} \mathrm{Co}_{0.1} \mathrm{O}_{2}$ are synthesized using the popular coprecipitation technique. Typically, the $\mathrm{Ni}_{0.8} \mathrm{Mn}_{0.1} \mathrm{Co}_{0.1}(\mathrm{OH})_{2}$ precursor is prepared by coprecipitation of stoichiometric amount of metal acetate and mixed with $\mathrm{LiOH} \cdot \mathrm{H}_{2} \mathrm{O}$ at a molar ratio of 1:1.05; then the product is fired at $\approx 450$ and $750{ }^{\circ} \mathrm{C}$ in $\mathrm{O}_{2}$ flow for 5-15 h [163]. Typical electrochemical features of NCMs are displayed in Figures 5 and 6 for powders synthesized by the coprecipitation method and heat treated at $750{ }^{\circ} \mathrm{C}$ in oxygen atmosphere. Li et al. [164] investigated the effect of sintering temperature on the electrochemical properties of NCM811 prepared by coprecipitation. The charge-discharge tests showed that NCM powders became better when the temperature increases from 700 to $750{ }^{\circ} \mathrm{C}$, while higher temperature deteriorated the performance. NCM811 with uniform particle size was obtained from $\mathrm{Ni}_{0.8} \mathrm{Mn}_{0.1} \mathrm{Co}_{0.1} \mathrm{O}_{2}$ precursor prepared by an atomization to form an aerosol via an ultrasonic nebulizer; then the aerosols introduced in a continuously stirring tank reactor (CSTR) were mixed with a $\mathrm{NaOH}+\mathrm{NH}_{4} \mathrm{OH}$ solution as chelating agent with $\mathrm{pH}$ held at 11.5 [165].

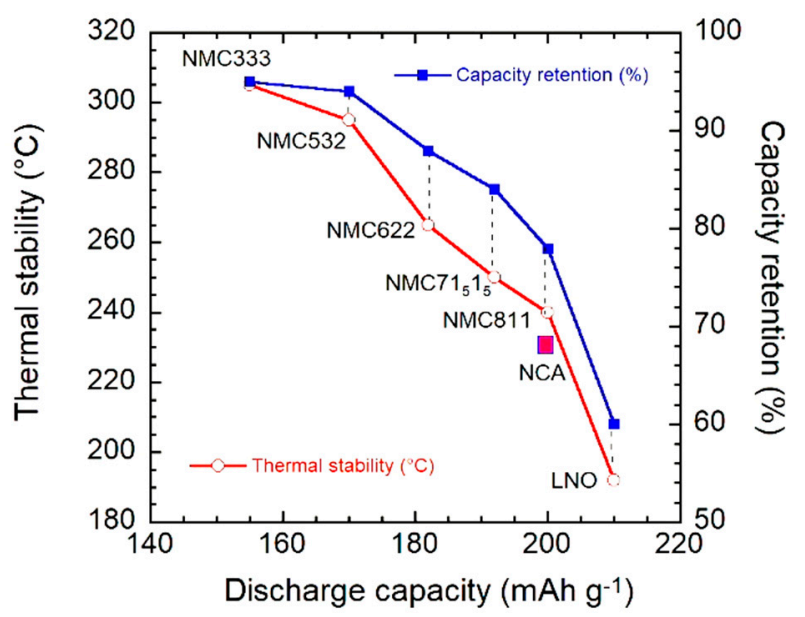

Figure 7. The composition-performance relationship of layered nickel-manganese-cobalt oxides (NCM). The choice of a cathode material is a compromise between the capacity delivered by the cell and its thermal stability.

Serious capacity degradation of NCM811 materials has been widely reported, i.e., residual lithium compounds ( $\mathrm{LiOH}, \mathrm{Li}_{2} \mathrm{CO}_{3}$ ), chemically unstable Ni-rich surface, antisite defects (cation mixing affecting the layered structure), release of $\mathrm{Ni}^{2+}$ ions, phase transformation at high state-of-charge (SOC), cracks arising from the volume change, and surface side reactions. Again, the strategies that have been employed to overcome these disadvantages are doping and surface coating. 


\subsection{Stabilization of NCM}

\subsubsection{Coating NCM}

Surface modifications of NCM811 are still considered as needed, even though precycling (five cycles at $0.1 \mathrm{C})$ at high voltage $(2.0-4.5 \mathrm{~V})$ and then cycling in lower cutoff voltage of $4.3 \mathrm{~V}$ proved to be sufficient to improve the stability of the cathode so efficiently that the capacity retention reached $83 \%$ after 500 cycles [166]. As a matter of fact, this forming process is a sort of coating process, as a $3 \mathrm{~nm}$ thick cation-mixing nanolayer $(\approx 3 \mathrm{~nm})$ with rock-salt structure is formed on the cathode surface which can efficiently impede further structural degradation. Nevertheless, this monolayer is insulating and coating with a more conductive material is needed to improve the rate capability.

Improved performance was obtained using a coating made of $\mathrm{SiO}_{2}$ [167], and metal oxides $\mathrm{MoO}_{3}$ [168], $\mathrm{WO}_{3}$ [169], $\mathrm{LaAlO}_{3}$ [170], $\mathrm{Al}_{2} \mathrm{O}_{3}$ [171-173], despite the fact that they are not redox-active. In particular, $\mathrm{Al}_{2} \mathrm{O}_{3}$ ALD-coated $\mathrm{LiNi}_{0.8} \mathrm{Co}_{0.1} \mathrm{Mn}_{0.1} \mathrm{O}_{2}$ cathode material delivered a capacity of $212.8 \mathrm{mAh} \mathrm{g}^{-1}$ with coulombic efficiency of $84 \%$ at $0.1 \mathrm{C}$ during the first cycle. After 100 cycles, this cathode still demonstrated a capacity of $157.2 \mathrm{mAh} \mathrm{g}^{-1}$, despite the fact that the cycles were performed in the broad voltage range of $2.7-4.6 \mathrm{~V} \mathrm{vs.} \mathrm{Li}^{+} / \mathrm{Li}$ [171]. Note, however, that this improvement linked to the $\mathrm{Al}_{2} \mathrm{O}_{3}$ coating is less impressive than in the case of NCA. This can be understood from the work of Han et al. who studied the effect of the composition of NCM on the surface alumina coatings [174]. These authors demonstrated that a good surface protection is achieved with $\mathrm{Al}_{2} \mathrm{O}_{3}$ coating on NCM532, but this protection effect is hindered when transition metal composition is changed to NCM622 or 811. The reason is the diffusion of surface $\mathrm{Al}_{2} \mathrm{O}_{3}$ into the bulk when the concentration of $\mathrm{Ni}$ is larger than 0.6, transforming the coating layer into a dopant, so that $\mathrm{Al}_{2} \mathrm{O}_{3}$ in Ni-rich $\mathrm{NCM}$ no longer acts as a coating layer, and the surface of NCM811 is no longer protected On another hand, good results were also obtained by coating with an ionic conductor of $\mathrm{Li}_{+}$ions [175,176], including $\mathrm{Li}_{2} \mathrm{TiO}_{3}$ [177], $\mathrm{Li}_{2} \mathrm{SiO}_{3}$ [178], $\mathrm{Li}_{3} \mathrm{VO}_{4}$ [179], $\mathrm{Li}_{3} \mathrm{PO}_{4}$ [180]. These coating layers protect the cathode surface against parasitic redox reaction occurring at the electrode/electrolyte interface. The result is illustrated in Figures 8 and 9 for the case of $\mathrm{Li}_{3} \mathrm{PO}_{4}$.

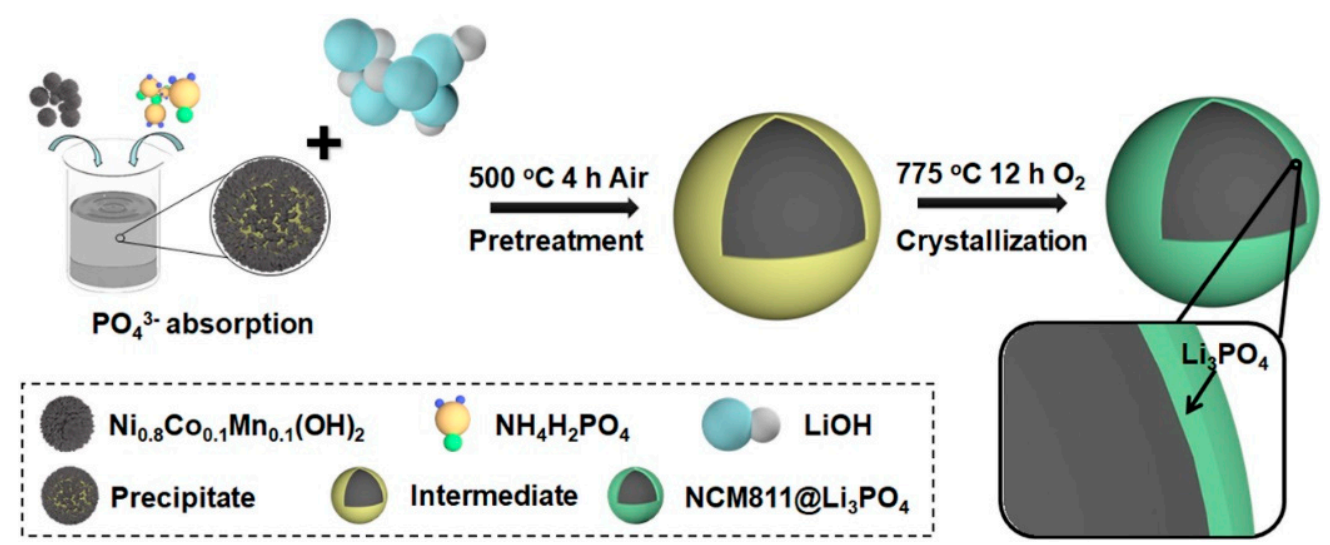

Figure 8. Schematic illustration for the fabrication of the $\mathrm{NCM} 811 @ \mathrm{Li}_{3} \mathrm{PO}_{4}$. Reproduced with permission from [180]. Copyright 2020 Elsevier. 
a
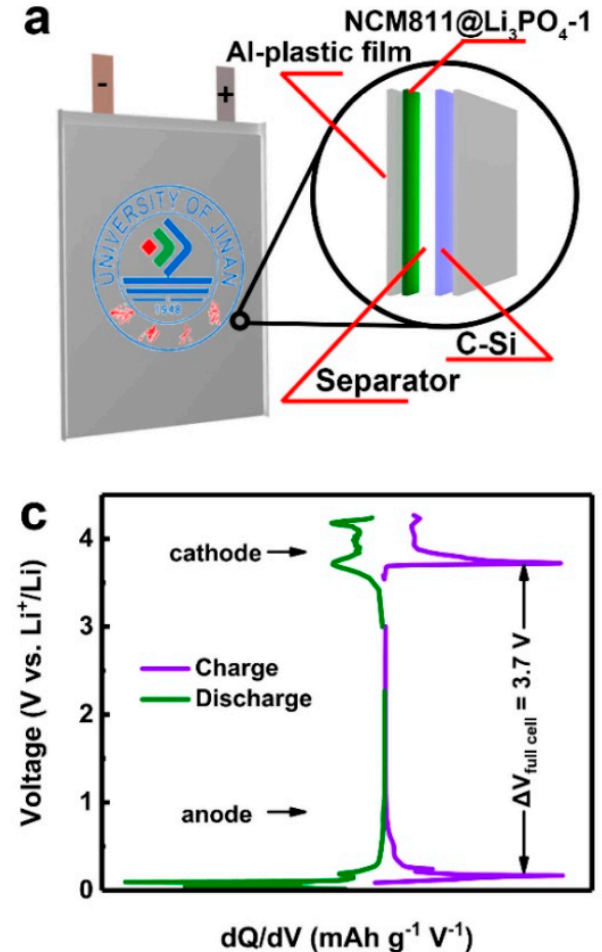
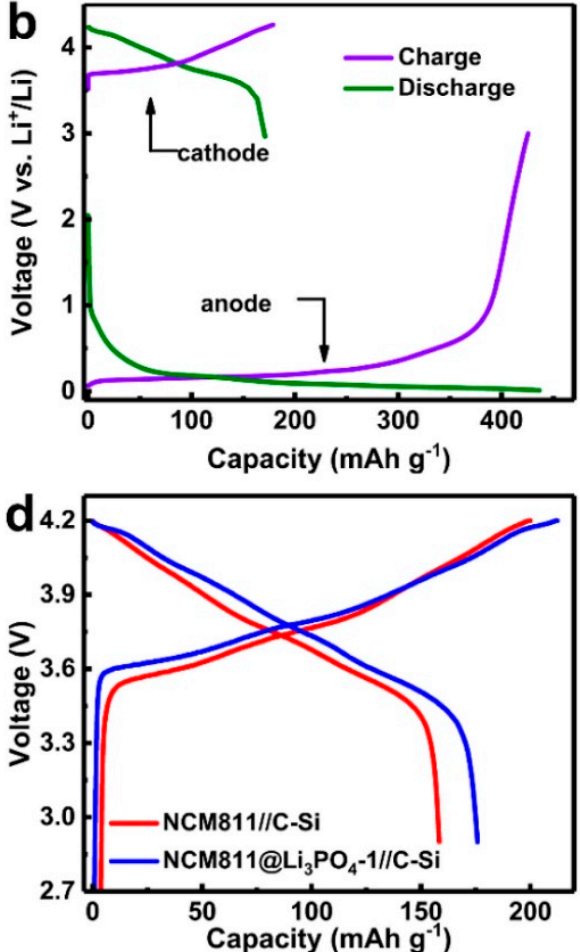

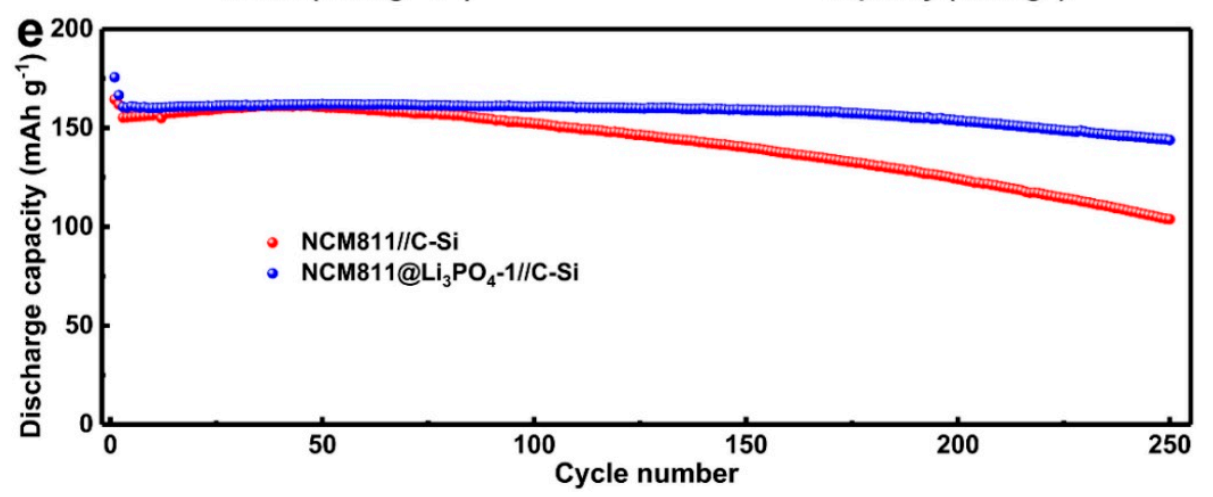

Figure 9. (a) Schematic illustration for the fabrication of the pouch-type full Li-ion cell with $\mathrm{NCM} 811 @ \mathrm{Li}_{3} \mathrm{PO}_{4}$ cathode and C-Si anode. Electrochemical properties of the full cell: (b) voltage-capacity curves and (c) differential capacity curves. (d) The initial charge-discharge plots $(0.1 \mathrm{C})$ and (e) long-term cycling stability (1.0 C). Reproduced with permission from [180]. Copyright 2020 Elsevier.

Coating can be realized using various methods: atomic layer deposition (ALD), wet process, sonication, in situ reaction. Remarkable results were obtained by atomic layer deposition of $\mathrm{LiAlF}_{4}$ on $\mathrm{LiNi}_{0.80} \mathrm{Mn}_{0.1} \mathrm{Co}_{0.1} \mathrm{O}_{2}$ [181]. When cycled at room temperature at $50 \mathrm{~mA} \mathrm{~g}^{-1}$ current density in the electrochemical voltage range of $2.75-4.50 \mathrm{~V} \mathrm{vs.} \mathrm{Li}^{+} / \mathrm{Li}$, the electrode with $\mathrm{LiAlF}_{4}$ coating demonstrated a capacity higher than $140 \mathrm{mAh} \mathrm{g}^{-1}$ after 300 cycles, which corresponds to $24 \%$ decay over 300 cycles. The poor cycle stability at elevated temperatures is a major problem for Ni-rich layered lithium metal oxides [182-184]. Testing the capacity retention at $50{ }^{\circ} \mathrm{C}$ is thus a real-world relevant test for NCM811. The $\mathrm{LiAlF}_{4}$-coated material at $50^{\circ} \mathrm{C}$ showed an excellent capacity retention with a capacity higher than $150 \mathrm{mAh} \mathrm{g}^{-1}$ after 100 cycles at a higher rate of $200 \mathrm{~mA} \mathrm{~g}^{-1}$. The epitaxial deposition of $\mathrm{Co}(\mathrm{OH})_{2}$ nanostructured stabilizer has shown to be efficient to suppress the nickel defects [79]. By a simple dry powder mixing technique, the $\mathrm{Co}(\mathrm{OH})_{2}$ precursor propagated along the grain boundary and transformed to $\mathrm{Co}_{3} \mathrm{O}_{4}$ above $300{ }^{\circ} \mathrm{C}$ constructing a transition-metal concentration gradient on the surface of NCM811 particles. Improvement of electrochemical performance of NCM811 was also achieved by graphene nanosheets (GrNs) modification [185]. The NCM811-GrN composite prepared 
by ultrasonication of the pristine material with reduced graphite oxide delivered an initial capacity of $213 \mathrm{mAh} \mathrm{g}^{-1}$ at $0.1 \mathrm{C}$ rate. The role of GrNs is twofold: first is to construct a three-dimensional conductive matrix for NCM8111 particles and second is to suppress the particle aggregation facilitating the electrolyte penetration. After Peng et al. who demonstrated the improvement of $\mathrm{Li}_{3} \mathrm{PO}_{4}-\mathrm{AlPO}_{4}$ coating [186], Feng et al. proposed a hybrid $\mathrm{Li}_{3} \mathrm{PO}_{4}-\mathrm{AlPO}_{4}-\mathrm{Al}\left(\mathrm{PO}_{3}\right)_{3}$ coating layer to obtain a synergetic effect of a ionic conductor $\left(\mathrm{Li}_{3} \mathrm{PO}_{4}\right)$ combined with the thermal stability of $\mathrm{AlPO}_{4}$. This coat was obtained via reacting $\mathrm{Al}\left(\mathrm{PO}_{3}\right)_{3}$ precursor with the residual lithium (under the form of $\mathrm{Li}_{2} \mathrm{CO}_{3}$ or/and $\mathrm{LiOH}$ ) at the surface [187]. The discharge capacity was raised to 201.8 and $218.9 \mathrm{mAh} \mathrm{g}^{-1}$ at 30 and 50 ${ }^{\circ} \mathrm{C}$ at $0.1 \mathrm{C}, 85.4 \%$ and $78.89 \%$ of which were retained after 50 cycles, respectively.

Coating with another phosphate, $\mathrm{FePO}_{4}$, which was shown to improve the electrochemical properties of NCA [108] was also probed with NCM811. The FePO ${ }_{4}$-coated NCM811 powders prepared via a sol-gel method demonstrated a capacity retention of $97 \%$ after 100 cycles and $86 \%$ after 400 cycles at $0.2 \mathrm{C}$ [188]. Since $\mathrm{FePO}_{4}$ is a good conductor, the rate capability was also increased, with a capacity maintained at $151.4 \mathrm{mAh} \mathrm{g}^{-1}$ at $5 \mathrm{C}$. $\mathrm{LaPO}_{4}$-coated $\mathrm{NCM} 811$ demonstrated $91.2 \%$ after 100 cycles at $1 \mathrm{C}$ [189], but has not been tested at $5 \mathrm{C}$. However, since $\mathrm{LaPO}_{4}$ is an insulator, the rate capability is expected to be reduced, with respect to that of $\mathrm{FePO}_{4}$-coated NCM811.

$\mathrm{B}_{2} \mathrm{O}_{3}$-coated $\mathrm{LiNi}_{0.83} \mathrm{Co}_{0.12} \mathrm{Mn}_{0.05} \mathrm{O}_{2}$ showed superior cyclic stability with a capacity retention of $96.8 \%$ and $87.7 \%$ at $1 \mathrm{C}$ after 100 and 200 cycles, respectively, against $69.4 \%$ after 200 cycles for the pristine sample [190]. This result was explained by the fact that $\mathrm{B}^{3+}$-doping surface triggers a reduction of a small amount of $\mathrm{Ni}^{3+}$ to $\mathrm{Ni}^{2+}$, in addition to the fact that it inhibits the irreversible phase transitions and extension of microcracks in the NCM material. It is worth noticing that these results are slightly better than those reported for the $\mathrm{Li}_{2} \mathrm{O}-\mathrm{B}_{2} \mathrm{O}_{3}(\mathrm{LBO})$-coated $\mathrm{LiNi}_{0.80} \mathrm{Co}_{0.15} \mathrm{Al}_{0.05} \mathrm{O}_{2}$ tested up to 100 cycles [113]. Since the concentration of $\mathrm{Al}$ and $\mathrm{Mn}$ are the same, this result suggests that the $\mathrm{Mn}$ in NCM has a role similar to that of Al in NCA with the same efficiency to stabilize the structure. The improvement of the electrochemical properties of NCM811 upon LBO coating has been demonstrated not only at room temperature [191], but also at elevated temperature of $60^{\circ} \mathrm{C}$ [192].

We have already mentioned the dual coating of NCA to obtain a coating layer that is both an electrical and an ionic conductor [125]. In NCM, a similar approach has been investigated by the use of polymers. Xiong et al. [193] reported the surface modification of NCM811 nanoparticles with conducting polypyrrole (PPy). The nanoscaled PPy coating was realized by facile chemical polymerization method using Fe(III) tosylate as oxidant and ethanol as solvent. Transmission electron microscopy depicted that NCM8111 served as hard template while the PPy layer formed a flocculent and nanofiber coating that effectively alleviated the side reactions between liquid electrolytes and the NCM811 surface. NCM811 was also coated with a dual-conductive layer composed of $\mathrm{Li}_{3} \mathrm{PO}_{4}$ and polypyrrole (PPy) [194]. On one hand, $\mathrm{Li}_{3} \mathrm{PO}_{4}$ could improve importantly the ionic conductivity, but also reduce the generation of HF. On the other hand, PPy formed a uniform film which increased the electrical conductivity, made up for the $\mathrm{Li}_{3} \mathrm{PO}_{4}$ coating defects, and its mechanical properties were efficient to reduce the generation of internal cracks. As a result, the coated-NCM811 delivered a capacity of $159.7 \mathrm{mAh} \mathrm{g}^{-1}$ at $10 \mathrm{C}\left(125.7 \mathrm{mAh} \mathrm{g}^{-1}\right.$ for the bare), with capacity retention of $95.1 \%$ at $0.1 \mathrm{C}$ after 50 cycles ( $86 \%$ for the bare). Cao et al. used the conductive polymers that integrate the excellent electronic conductivity of polyaniline (PANI) and the high ionic conductivity of poly(ethylene glycol) (PEG) to coat NMC811 with a homogeneous and thorough PANI-PEG layer [195]. The reversible capacity at $0.2 \mathrm{C}$ at room temperature was $206 \mathrm{mAh} \mathrm{g}^{-1}$, with capacity of $88.4 \%$ after 100 cycles. The rate capability was demonstrated by a capacity of $156.7 \mathrm{mAh} \mathrm{g}^{-1}$ at $10 \mathrm{C}$. At $1 \mathrm{C}$, the capacity retention at $55^{\circ} \mathrm{C}$ was $81.4 \%$ after 100 cycles (53.6\% for the bare NCM811). Other conductive polymers were considered as materials for coating NCM, such as poly(3,4-ethylenedioxythiophene) (PEDOT) [196-198]. However, the polymers do not have any orientation, so that the uniformity of the coating is not warranted and the results not always reproducible. This consideration led Jerng to propose covalent organic frameworks (COFs) as coating materials for NCM, and among them pyrazine (Pyr-2D) contains two nitrogen atoms in its aromatic ring [199]. The advantage of Pyr-2D is not only its planar morphology, but also 
conjugated bond configuration. Indeed, the Pyr-2D coating improved importantly the electrochemical properties of NCM811 electrodes. In particular, this cathode material was found to be stable in the potential range $2.8-4.5 \mathrm{~V}$, which was thus used to determine the capacity and rate capability. At $600 \mathrm{~mA} \mathrm{~g}^{-1}(1 \mathrm{C})$, the electrode retained $88.8 \%$ capacity after 100 cycles. At $2 \mathrm{C}$, the capacity was

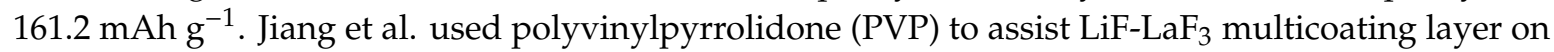
NCM811 by wet coating process. As a cathode, the coated NCM811 delivered a capacity of $173.6 \mathrm{mAh}$ $\mathrm{g}^{-1}$ with the capacity retention of $91.71 \%$ after 100 cycles at a high rate of $5 \mathrm{C}$ [200].

$\mathrm{Li}_{1.5} \mathrm{Al}_{0.5} \mathrm{Zr}_{1.5}\left(\mathrm{PO}_{4}\right)_{3}(\mathrm{LAZP})$-coated $\mathrm{NCM} 811$ cathode was recently fabricated by a sol-gel method [201]. The thickness of the NASICON fast ion-conductor LAZP film was $4 \mathrm{~nm}$. As a cathode, the capacity retention was $78.3 \%$ after 300 cycles at $1 \mathrm{C}$ in voltage of $2.8-4.3 \mathrm{~V}$. Moreover, at the higher cutoff voltage of $4.5 \mathrm{~V}$, a sustained reversible capacity of $179.3 \mathrm{mAh} \mathrm{g}^{-1}$ was demonstrated, corresponding to capacity retention of $84.8 \%$ after 200 charge/discharge cycles.

$\mathrm{SnO}_{2}$-coated NCM811 cathode prepared by ball-milling post treatment [202]. For a 3 wt.\% $\mathrm{SnO}_{2}$-coat, the capacity at $0.2 \mathrm{C}$ was $187.5 \mathrm{mAh} \mathrm{g}^{-1}$, with a capacity retention of $90.77 \%$ over 50 cycles. Note the results on $\mathrm{SnO}_{2}$-coated NCA were more impressive with a retention of $91.70 \%$ after 200 cycles at $1 \mathrm{C}$ rate at $60{ }^{\circ} \mathrm{C}$ [99].

Se-coated NCM811 microspherical cathode materials were prepared via a facile melt-diffusion approach by Ding et al. [203]. Typically, the selenium powder and the NCM811 microspheres were homogenously mixed and then heated at $280{ }^{\circ} \mathrm{C}$ for $10 \mathrm{~min}$ under the $\mathrm{N}_{2}$ atmosphere. At this temperature, melt-Se diffuses along the NCM811 microsphere surfaces to achieve the Se-coated NCM811 microspherical cathode materials. This Se-coated NCM811 delivered an initial capacity of $205 \mathrm{mAh} \mathrm{g}^{-1}$ at $0.2 \mathrm{C}, 173 \mathrm{mAh} \mathrm{g}^{-1}$ at the 100 th cycle at $0.2 \mathrm{C}, 132 \mathrm{mAh} \mathrm{g}^{-1}$ at 200 th cycle at $2 \mathrm{C}$, and $103 \mathrm{mAh} \mathrm{g}^{-1}$ at 300 th cycle at $5 \mathrm{C}$. Note the coating process is not only simple, but also efficient. The drawback, however, is that Se is very expensive, which might be prohibitive for practical use at an industrial scale. However, the facile melt-diffusion approach should be promising to coat NCM with other materials.

Recently, however, Chen et al. [204] overcame the problem of surface side reactions between cathode and electrolyte by coating with Li-reactive materials, i.e., $\mathrm{Co}_{3} \mathrm{O}_{4}$ and $\mathrm{LiMn}_{2} \mathrm{O}_{4}$ spinel layers, which removed the residual lithium compounds $\left(\mathrm{LiOH}, \mathrm{LiCO}_{3}\right)$ on the particle surface. During charge and discharge process, the fine surface structure resulted from the generated cubic spinel phase, which suppresses volume change and thus inhibits the formation of surface cracks. Note, however, that $\mathrm{Co}_{3} \mathrm{O}_{4}$-coated NCM811 did not improve the electrochemical properties with respect to $\mathrm{Co}_{3} \mathrm{O}_{4}$-coated [96]. In addition, it adds extra $\mathrm{Co}$, while many efforts are presently made to get rid of it. Ryu et al. [205] investigated the storage-induced degradation of NCM811 material and demonstrated an effective way to eliminate the undesirable Li residues via a phosphate treatment, which also suppresses the loss of particle integrity by $\mathrm{H}_{2} \mathrm{O}$ and $\mathrm{CO}_{2}$ infiltration.

Another interesting material design is the full concentration-gradient, which consists in the decrease of $\mathrm{Ni}$ content and increase of $\mathrm{Co}$ and Mn content across the particle radius $(6 \mu \mathrm{m})$ [206]. Samples were prepared in a continuously stirring tank reactor containing stoichiometric 811 solution, Ni-poor (111) solution and $\mathrm{NH}_{3} \cdot \mathrm{H}_{2} \mathrm{O}$ as the chelating agent. The EDX spectra showed that the outer surface composition was $\mathrm{Li}\left(\mathrm{Ni}_{0.56} \mathrm{Co}_{0.21} \mathrm{Mn}_{0.23}\right) \mathrm{O}_{2}$. Not only high discharge capacity, but also good cyclic stability and rate performance were achieved. This cathode delivered a high initial discharge capacity of $\approx 203 \mathrm{mAh} \mathrm{g}{ }^{-1}$ and a capacity retention of $87.4 \%$ after 100 cycles at $55{ }^{\circ} \mathrm{C}(4.3 \mathrm{~V}$ cut-off voltage and $1 \mathrm{C}$ rate). Selected examples of coating technology are listed in Table 3. 
Table 3. Characteristics and electrochemical performance of NCM811 electrodes coated with various substances (CR = capacity retention).

\begin{tabular}{|c|c|c|c|}
\hline Coating & Preparation & Electrochemical Performance & Ref. \\
\hline $\mathrm{Li}_{2} \mathrm{SiO}_{3}$ & $\begin{array}{l}\text { Solvothermal method } \\
\text { using } \mathrm{Si}\left(\mathrm{OC}_{2} \mathrm{H}_{5}\right)_{4} \text { and } \\
\qquad \mathrm{LiOH}\end{array}$ & $\begin{array}{c}133 \mathrm{mAh} \mathrm{g}^{-1} \text { after } 52 \text { cycles at current } \\
\text { density of } 100 \mathrm{~mA} \mathrm{~g}^{-1} \text { in the voltage } \\
\text { range } 3.0-4.6 \mathrm{~V}\end{array}$ & [178] \\
\hline $\mathrm{Li}_{2} \mathrm{TiO}_{3}$ & $\begin{array}{c}\text { Nanobelts obtained from } \\
\text { reaction between } \\
\mathrm{MC}_{2} \mathrm{O}_{4} \cdot \mathrm{xH}_{2} \mathrm{O} \text { and } \\
\mathrm{Ti}\left(\mathrm{OC}_{4} \mathrm{H}_{9}\right)_{4}\end{array}$ & $\begin{array}{c}150 \mathrm{mAh} \mathrm{g}^{-1} \text { at } 0.5 \mathrm{C} \text { in the voltage } \\
\text { range } 3.0-4.3 \mathrm{~V} ; \mathrm{CR} \text { of } 92 \% \text { after } 100 \\
\text { cycles at } 2 \mathrm{C} \text { rate }\end{array}$ & [177] \\
\hline $\mathrm{Li}_{3} \mathrm{VO}_{4}(3$ wt. $\%)$ & $\begin{array}{l}\text { Wet chemistry using } \\
\mathrm{V}_{2} \mathrm{O}_{5} \text { and } \mathrm{LIOH} \cdot \mathrm{H}_{2} \mathrm{O}\end{array}$ & $\begin{array}{l}164 \mathrm{mAh} \mathrm{g}^{-1} \text { at } 0.1 \mathrm{C} \text { in the voltage } \\
\text { range } 2.0-4.3 \mathrm{~V} ; \mathrm{CR} \text { of } 83 \% \text { after } 100 \\
\text { cycles at } 1 \mathrm{C} \text { rate }\end{array}$ & [179] \\
\hline $\begin{array}{c}\mathrm{MoO}_{3} / \mathrm{Li}_{2} \mathrm{MoO}_{4} \\
(3 \mathrm{wt} . \%)\end{array}$ & $\begin{array}{l}\text { Dry coating method } \\
\text { using } \\
\left(\mathrm{NH}_{4}\right)_{6} \mathrm{Mo}_{7} \mathrm{O}_{24} \cdot 4 \mathrm{H}_{2} \mathrm{O}\end{array}$ & $\begin{array}{c}200 \mathrm{mAh} \mathrm{g}^{-1} \text { at } 0.1 \mathrm{C} \text { rate in the voltage } \\
\text { range } 2.8-4.3 \mathrm{~V} ; \mathrm{CR} \text { of } 94.8 \% \text { after } 100 \\
\text { cycles at } 1 \mathrm{C}\end{array}$ & [168] \\
\hline $\mathrm{Li}_{3} \mathrm{PO}_{4}$ & $\begin{array}{c}\text { In situ coating in } \\
\mathrm{NH}_{4} \mathrm{H}_{2} \mathrm{PO}_{4} \text { solution }\end{array}$ & $\begin{array}{c}176 \mathrm{mAh} \mathrm{g}^{-1} \text { at } 0.1 \mathrm{C} \text { rate in the voltage } \\
\text { range } 2.9-4.2 \mathrm{~V} ; \mathrm{CR} \text { of } 89.6 \% \text { after } 250 \\
\text { cycles at } 1 \mathrm{C}\end{array}$ & [180] \\
\hline $\mathrm{Li}_{3} \mathrm{PO}_{4}$-PPy co-coating & $\begin{array}{l}\text { Two-step: wet-coating } \\
\text { for } \mathrm{Li}_{3} \mathrm{PO}_{4} / \text { chem. } \\
\text { polymer. PPy }\end{array}$ & $\begin{array}{c}159 \mathrm{mAh} \mathrm{g}^{-1} \text { at } 10 \mathrm{C} \text { rate in the voltage } \\
\text { range } 2.8-4.5 \mathrm{~V} ; \mathrm{CR} \text { of } 95.1 \% \text { after } 50 \\
\text { cycles at } 0.1 \mathrm{C}\end{array}$ & [194] \\
\hline $\begin{array}{l}\mathrm{Li}_{3} \mathrm{PO}_{4}-\mathrm{AlPO}_{4} \\
\text { co-coating }\end{array}$ & $\begin{array}{c}\mathrm{Al}\left(\mathrm{H}_{2} \mathrm{PO}_{4}\right)_{3} \text { added to } \\
\text { ethyl alcohol }\end{array}$ & $\begin{array}{c}182.8 \mathrm{mAh} \mathrm{g}^{-1} \text { at } 1 \mathrm{C} \text { in the range } \\
2.8-4.3 \mathrm{~V} ; \mathrm{CR} \text { of } 91.79 \% \text { after } 100 \text { cycles } \\
\text { at } 1 \mathrm{C}\end{array}$ & [186] \\
\hline $\begin{array}{l}\mathrm{Li}_{3} \mathrm{PO}_{4}-\mathrm{AlPO}_{4}-\mathrm{Al}\left(\mathrm{PO}_{3}\right)_{3} \\
\text { coating }\end{array}$ & $\begin{array}{l}\mathrm{Al}\left(\mathrm{PO}_{3}\right)_{3} \text { in ethanol } \\
\text { reacting with NCM811 }\end{array}$ & $\begin{array}{c}201.8 \mathrm{mAh} \mathrm{g}^{-1} \text { at } 0.1 \mathrm{C} \text { in the range } \\
3.0-4.3 \mathrm{~V} ; \mathrm{CR} \text { of } 85.4 \% \text { after } 50 \text { cycles at } \\
0.1 \mathrm{C}\end{array}$ & [187] \\
\hline $\mathrm{FePO}_{4}$ & Sol-gel method & $\begin{array}{c}151.4 \mathrm{mAh} \mathrm{g}^{-1} \text { at } 5 \mathrm{C} \text { in the voltage } \\
\text { range } 2.74-4.5 \mathrm{~V} ; \mathrm{CR} \text { of } 86 \% \text { after } 400 \\
\text { cycles at } 0.2 \mathrm{C}\end{array}$ & [188] \\
\hline $\mathrm{LiAlF}_{4}$ & ALD & $\begin{array}{l}184 \mathrm{mAh} \mathrm{g}^{-1} \text { at } 50 \mathrm{~mA} \mathrm{~g}^{-1} \text { in the } \\
\text { voltage range } 2.74-4.5 \mathrm{~V} ; \mathrm{CR} \text { of } 76 \% \\
\text { after } 300 \text { cycles }\end{array}$ & [181] \\
\hline $\mathrm{LiF}_{-} \mathrm{LaF}_{3}$ & $\begin{array}{l}\text { Polyvinyl } \\
\text { pyrrolidone-assisted wet } \\
\text { coating process }\end{array}$ & $\begin{array}{c}173.6 \mathrm{mAh} \mathrm{g}^{-1} \text { at } 5 \mathrm{C} \text { in the voltage } \\
\text { range } 2.8-4.6 \mathrm{~V} ; \mathrm{CR} \text { at } 81.8 \% \text { after } 100 \\
\text { cycles at } 5 \mathrm{C}\end{array}$ & [200] \\
\hline $\mathrm{SiO}_{2}$ & $\begin{array}{l}\text { Aqueous solution } \\
\text { method using } \\
\mathrm{Na}_{2} \mathrm{SiO}_{3} \cdot 9 \mathrm{H}_{2} \mathrm{O} \\
\end{array}$ & $\begin{array}{c}185 \mathrm{mAh} \mathrm{g}^{-1} \text { at } 1 \mathrm{C} \text { rate in the voltage } \\
\text { range } 2.8-4.3 \mathrm{~V} ; \mathrm{CR} \text { of } 90 \% \text { after } 300 \\
\text { cycles }\end{array}$ & [167] \\
\hline $\mathrm{LaAlO}_{3}(3$ wt. $\%)$ & $\begin{array}{l}\text { Solid method, using } \\
\mathrm{La}\left(\mathrm{NO}_{3}\right)_{3} \cdot 6 \mathrm{H}_{2} \mathrm{O} \text { and } \\
\mathrm{Al}\left(\mathrm{CH}\left(\mathrm{CH}_{3}\right)_{2} \mathrm{O}\right)_{3}\end{array}$ & $\begin{array}{c}155 \mathrm{mAh} \mathrm{g}^{-1} \text { at } 1 \mathrm{C} \text { rate in the voltage } \\
\text { range } 2.7-4.3 \mathrm{~V} ; \mathrm{CR} \text { of } 84.5 \% \text { after } 200 \\
\text { cycles at } 1 \mathrm{C}\end{array}$ & [170] \\
\hline $\mathrm{LaPO}_{4}$ & $\begin{array}{l}\text { Wet chemistry } \\
\text { aqueous solution with } \\
\mathrm{La}\left(\mathrm{NO}_{3}\right)_{3} \cdot 6 \mathrm{H}_{2} \mathrm{O}+ \\
\mathrm{NH}_{4} \mathrm{H}_{2} \mathrm{PO}_{4}\end{array}$ & $\begin{array}{c}200 \mathrm{mAh} \mathrm{g}^{-1} \text { at } 0.1 \mathrm{C} \text { rate in the voltage } \\
\text { range } 3.0-4.3 \mathrm{~V} ; \mathrm{CR} \text { of } 91.2 \% \text { after } 100 \\
\text { cycles at } 1 \mathrm{C}\end{array}$ & [189] \\
\hline $\mathrm{AlPO}_{4}(0.5$ wt.\%) & $\begin{array}{l}\text { Ethyl alcoholic solution } \\
\text { with } \mathrm{Al}\left(\mathrm{H}_{2} \mathrm{PO}_{4}\right)_{3} \text { at } 50{ }^{\circ} \mathrm{C}\end{array}$ & $150 \mathrm{mAh} \mathrm{g}^{-1}$ at $10 \mathrm{C}$ rate & [186] \\
\hline $\mathrm{Co}_{3} \mathrm{O}_{4}(0.6$ wt. $\%)$ & $\begin{array}{c}\text { Sonication in ethanol } \\
\text { solution with } \mathrm{Co}(\mathrm{OH})_{2}\end{array}$ & $186 \mathrm{mAh} \mathrm{g}^{-1}$ at $1 \mathrm{C}$ rate after 100 cycles & [204] \\
\hline $\mathrm{WO}_{3}(0.25$ wt.\%) & $\begin{array}{l}\text { Wet process in alcohol } \\
\text { using } \mathrm{WO}_{3} \text { dissolved in } \\
\qquad \mathrm{H}_{2} \mathrm{O}_{2}\end{array}$ & $\begin{array}{c}189 \mathrm{mAh} \mathrm{g}^{-1} \text { at } 0.2 \mathrm{C} \text { rate in the voltage } \\
\text { range } 2.8-4.3 \mathrm{~V} ; \mathrm{CR} \text { of } 70 \% \text { after } 100 \\
\text { cycles at } 1 \mathrm{C}\end{array}$ & [169] \\
\hline
\end{tabular}


Table 3. Cont.

\begin{tabular}{|c|c|c|c|}
\hline Coating & Preparation & Electrochemical Performance & Ref. \\
\hline $\begin{array}{c}\mathrm{Li}_{1.5} \mathrm{Al}_{0.5} \mathrm{Zr}_{1.5}\left(\mathrm{PO}_{4}\right)_{3} \\
(1 \text { wt. } \%)\end{array}$ & Sol-gel method & $\begin{array}{c}179.3 \mathrm{mAh} \mathrm{g}^{-1} \text { at } 1 \mathrm{C} \text { in the voltage } \\
\text { range } 2.84 .5 \mathrm{~V} ; \mathrm{CR} \text { at } 84.8 \% \text { after } 200 \\
\text { cycles at } 1 \mathrm{C}\end{array}$ & [201] \\
\hline PANI-PEG & $\begin{array}{l}\text { One step wet-coating } \\
\text { method }\end{array}$ & $\begin{array}{c}156.7 \mathrm{mAh} \mathrm{g}^{-1} \text { at } 10 \mathrm{C} \text { in the voltage } \\
\text { range } 2.8-4.3 \mathrm{~V} ; \mathrm{CR} \text { of } 88.4 \% \text { after } 100 \\
\text { cycles at } 2 \mathrm{C}\end{array}$ & [195] \\
\hline $\begin{array}{c}\text { PEDOT-coated } \\
\mathrm{LiNi}_{0.85} \mathrm{Co}_{0.1} \mathrm{Mn}_{0.05} \mathrm{O}_{2}\end{array}$ & CVD process & $\begin{array}{c}178 \mathrm{mAh} \mathrm{g}^{-1} \text { at } 1 \mathrm{C} \text { rate in the voltage } \\
\text { range } 2.7-4.3 \mathrm{~V} ; \mathrm{CR} \text { of } 91 \% \text { after } 100 \\
\text { cycles at } 1 \mathrm{C}\end{array}$ & [196] \\
\hline Pyr-2D & $\begin{array}{l}\text { Reaction of amine and } \\
\text { ketone in presence of } \\
\text { NCM }\end{array}$ & $\begin{array}{c}175 \mathrm{mAh} \mathrm{g}^{-1} \text { at } 1 \mathrm{C} \text { rate; } \mathrm{CR} \text { of } 88.8 \% \\
\text { after } 100 \text { cycles at } 1 \mathrm{C} \text {; voltage range } \\
2.8-4.5 \mathrm{~V}\end{array}$ & [199] \\
\hline
\end{tabular}

The concept of core-shell (CS) consists in the synthesis of particles with Ni-enriched core to maximize the capacity and a Ni-depleted shell to avoid the problems met with the surface layer of the Ni-rich materials. This strategy has been employed for more than a decade, with NCM811 core and $\mathrm{LiNi}_{0.5} \mathrm{Mn}_{0.5}$ shell [207-210], and the progress using this strategy was constant through the years [211-214].

\subsubsection{Choice of the Core-Shell Structure}

Jun et al. synthesized a CS cathode, consisting of spherical particles with a $\mathrm{LiNiO} 2$ core and a $0.5 \mu \mathrm{m}$ thick NCM811 shell. The average composition was thus $\mathrm{Li}\left[\mathrm{Ni0} 0.95 \mathrm{Co} 0.025 \mathrm{Mn} 0.025 \mathrm{O}_{2}\right.$ [215]. In the corresponding full-cell against the graphite anode between 3.0 and $4.2 \mathrm{~V}$ at $1 \mathrm{C}$, the discharge capacity was nearly $190 \mathrm{mAh} \mathrm{g}^{-1}$, retained at $165 \mathrm{mAh} \mathrm{g}^{-1}$ after 1000 cycles, performance that paves the route to the synthesis of lithium-ion batteries with higher energy density. Li et al. fabricated a CS-structured NCM811@0.03[Li-Mn-O] which delivered a capacity of $118 \mathrm{mAh} \mathrm{g}^{-1}$ with almost $82 \%$ retention after 200 cycles at the high rate of $10 \mathrm{C}$, thanks to the stable spinel-structured shell which provided 3D paths for $\mathrm{Li}^{+}$diffusion, while the Ni-rich core insured the high capacity [216]. For the same reason, CS-structured $\left.\mathrm{Li}\left[\mathrm{Ni}_{0.8} \mathrm{Co}_{0.1} \mathrm{Mn}_{0.1}\right)_{0.9} @ \mathrm{Ni}_{1 / 3} \mathrm{Co}_{1 / 3} \mathrm{Mn}_{1 / 3}\right)_{0.1} \mathrm{O}_{2}$ delivered a capacity of $153 \mathrm{mAh} \mathrm{g}^{-1}$ with $90 \%$ capacity retention after 100 cycles at $2 \mathrm{C}$ rate at $60{ }^{\circ} \mathrm{C}$ [217]. These results illustrate the superiority of the CS-structured NMC at high temperature and high rate, provided the shell thickness is smaller than $700 \mathrm{~nm}$ [218]. To take full advantage of Ni-rich inner layers and Mn-rich outer layers, a two-sloped full-concentration gradient cathode (denoted as TSFCG) was developed, with a steep gradient in the vicinity of the surface, to reach fast an extended Ni-rich part [219]. The TSFCG-Li[Ni $\left.\mathrm{Ni}_{0.8} \mathrm{Co}_{0.06} \mathrm{Mn}_{0.14}\right] \mathrm{O}_{2}$ with the outer surface composition of $\mathrm{Li}\left[\mathrm{Ni}_{0.64} \mathrm{Co}_{0.06} \mathrm{Mn}_{0.30}\right] \mathrm{O}_{2}$ demonstrated $94.6 \%$ capacity retention after 100 cycles at $C / 2$ rate $\left(105 \mathrm{mAh} \mathrm{g}^{-1}, 2.7-4.3 \mathrm{~V}\right)$. In addition, $\mathrm{Al}$ can be incorporated as a dopant to lower the cation mixing and improve the structural stability. The TSFCG-Li[ $\mathrm{Ni}_{0.84} \mathrm{Co}_{0.06} \mathrm{Mn}_{0.09} \mathrm{Al}_{0.01} \mathrm{O}_{2}$ [220]. After 100 cycles at $0.5 \mathrm{C}$, the capacity maintained at $197 \mathrm{mAh} \mathrm{g}^{-1}$ (capacity retention of $95.1 \%$ ) at $4.3 \mathrm{~V}$ and $202 \mathrm{mAh} \mathrm{g}^{-1}$ (capacity retention of $90 \%$ ) at $4.5 \mathrm{~V}$.

\subsubsection{Doping NCM}

Another way of stabilizing the structure of NCM is lattice doping with various cations. In the recent years, we can cite doping of NCM 523 with niobium [221] and $\mathrm{Nd}^{3+}$ [222]. In the particular case of NCM811 a "top-down" approach has been developed by Weigel et al. for doping with $\mathrm{Mg}^{2+}$, $\mathrm{Al}^{3+}, \mathrm{Si}^{4+}, \mathrm{Ti}^{4+}, \mathrm{Zr}^{4+}, \mathrm{Ta}^{5+}$ [223]. Attempts to mitigate the volume change and the degradation of the material include doping with calcium [224] and molybdenum [225].

The addition of $\mathrm{Zr}$ leads to the coating of NCM811 with a $\mathrm{Li}_{2} \mathrm{ZrO}_{3}[226,227]$, simultaneously with $\mathrm{Zr}^{4+}$ doping [228-231]. In particular, He et al. synthesized NMC811 doped with gradient concentration of $\mathrm{Zr}^{4+}$ with the $\mathrm{Zr}$-rich $\mathrm{Li}_{2} \mathrm{ZrO}_{3}$ surface layer [229]. The $\mathrm{Li}_{2} \mathrm{ZrO}_{3}$ stabilizes the structure and avoids 
side reactions with the electrolyte, thanks to the strong $\mathrm{Zr}-\mathrm{O}$ bond. The $\mathrm{Zr}^{4+}$ dopant has an ionic radius similar to that of $\mathrm{Li}^{+}$, so that it occupies partly the $\mathrm{Li}$ slabs, reducing the exchange between $\mathrm{Ni}^{2+}$ and $\mathrm{Li}^{+}$(cation mixing), even though it increases the amount of $\mathrm{Ni}^{2+}$ for charge compensation. Thus modified, this cathode material delivered a capacity of $164.7 \mathrm{mAh} \mathrm{g}^{-1}$ at $10 \mathrm{C}$ and $83.2 \%$ capacity retention after 200 cycles at $1 \mathrm{C}$ between 2.8 and $4.5 \mathrm{~V}$. $\mathrm{Cr}^{3+}$ plays a similar role, since its ionic radius is also similar to that of $\mathrm{Ni}^{2+}$, provided that the $\mathrm{Cr}$-concentration remains small enough to avoid the formation of $\mathrm{Cr}^{6+}$ on Li-sites [232]. Zhang et al. [233] reported the effect of Ti doping (0.005 mol) on the structural and electrochemical properties of NCM811 prepared by ball-milling technique (particle size of 200-300 nm after $1 \mathrm{~h}$ milling). XRD and XPS analyses indicated that the $\mathrm{Ti}^{4+}$ ions partly substituted the interlayer $\mathrm{Li}$ sites and the intralayer $\mathrm{Co}^{3+}$ and $\mathrm{Mn}^{4+}$ positions to retain charge balance in doped NCM material. It showed a high initial specific capacity of $215 \mathrm{mAh} \mathrm{g}^{-1}$ at $0.1 \mathrm{C}$ rate, good rate capability (137 $\mathrm{mAh} \mathrm{g}^{-1}$ at $5 \mathrm{C}$ ) and cyclic stability (coulombic efficiency of $86.5 \%$ after 50 cycles at $5 \mathrm{C}$ ). It was stated that $\mathrm{Ti}$ doping could decrease the cation disordering and enhance the Li layer spacing with easier $\mathrm{Li}^{+}$ion transport to de-intercalate (charge) and intercalate (discharge). In a comparison between $\mathrm{Ti}, \mathrm{Mg}$, and Al-doping, Jiang et al. found that Ti-doping is the most efficient to reduce the cation mixing, and strengthens the most the Ni-O bond, thus reducing gas evolution and increasing thermal and structural stability [234]. The Ti-doped NCM811 electrode exhibited a capacity retention of $93.8 \%$ after 200 cycles at 1 C. Sun et al. used a low cost and scalable hydrolysis step to introduce Ti into NCM811 precursor. With a following high-temperature solid-state reaction, Ti diffuses into NCM811 crystals and homogeneously distributed in bulk secondary particles [235]. Ti can effectively enhance ion transfer kinetics and thus greatly improve capacity delivery at high $\mathrm{C}$ rates. In addition, the amount of $\mathrm{Ni}^{2+}$ in $\mathrm{Li}$ sites was decreased from $6.76 \%$ to $3.13 \%$, thanks to the charge compensation provided by $\mathrm{Ti}^{4+}$ to balance electrostatic repulsion. While the upper voltage is usually limited to $4.3 \mathrm{~V}$ to avoid the fast decrease of the cycle life due to the $\mathrm{H} 2 \rightarrow \mathrm{H} 3$ transition, Sun et al. performed long cycling tests on the Ti-doped NMC 811 in voltage window of $2.8-4.6 \mathrm{~V} \mathrm{vs}$. $\mathrm{Li}^{+} / \mathrm{Li}$ at $1 \mathrm{C}$. Under such conditions, the Ti-doped NMC 811 delivered a capacity of $166 \mathrm{mAh} \mathrm{g}^{-1}$ with a capacity retention of $84 \%$ over 100 cycles, which is higher than pristine NCM811 $\left(70 \%, 135 \mathrm{mAh} \mathrm{g}^{-1}\right)$. Na-doping of NCM811 has also been has also been explored, but is not sufficient to prevent the active material from being dissolved in the electrolyte and maintain its structural stability. On another hand, a synergistic modification of sodium ion doping and silica coating was proposed by Zeng et al. [236].

With $\mathrm{Zr}^{4+}, \mathrm{Mg}^{2+}$ is the other ion that can occupy the Li sites. Sattar et al. reported that $1 \mathrm{wt} \%$ Mg-doped $\mathrm{LiNi}_{0.84} \mathrm{Co}_{0.11} \mathrm{Mn}_{0.05} \mathrm{O}_{2}$ delivers the discharge capacity of $196.7 \mathrm{mAh} \mathrm{g}^{-1}(0.1 \mathrm{C})$ and maintains the capacity retention of $85.95 \%$ after 80 cycles, due to the suppression of the phase transition between $\mathrm{H} 2$ and $\mathrm{H} 3$ [237].

Considering the success of $\mathrm{Al}^{3+}$ doping in NCA, either homogeneous or with $\mathrm{Al}$ concentration gradient, including in a material with average composition $\mathrm{LiNi}_{0.815} \mathrm{Co}_{0.15} \mathrm{Al}_{0.035} \mathrm{O}_{2}$ close to the composition on which we have focused attention in this review [238], many works have explored $\mathrm{Al}^{3+}$ in NCM, with formation of homogeneous [239-241], concentration-gradient [242,243]. In particular, the improvement of the cycle ability of the Al-doped NCM523 and aging of the cathode in a charged state $(4.3 \mathrm{~V})$ at $60{ }^{\circ} \mathrm{C}$ results from two effects: (i) the chemical and structural modifications of the solid-electrolyte interface [26], (ii) the stabilization of the structure of NCM via strong Al-O bonding owing to a $\mathrm{Al}(\mathrm{s})-\mathrm{O}(\mathrm{p})$ overlap [244]. More recently, a $\%$ molar weight of $\mathrm{Al}^{3+}$ doping of $\mathrm{LiNi}_{0.88} \mathrm{Co}_{0.095} \mathrm{Mn}_{0.025} \mathrm{O}_{2}$ was reported by Yang et al. using an original process [245]. First, laminar primary grains were embedded into the $\mathrm{Ni}_{0.88} \mathrm{Co}_{0.095} \mathrm{Mn}_{0.025}(\mathrm{OH})_{2}$ precursor. Then, calcination of the precursor with surface-dispersed nano- $\mathrm{Al}_{2} \mathrm{O}_{3}$ was made to obtain a homogeneous $\mathrm{Al}^{3}$ doping, with radial arrangement of the primary grains. The $\mathrm{LiNi}_{0.88} \mathrm{Co}_{0.095} \mathrm{Mn}_{0.025} \mathrm{O}_{2}-\mathrm{Al}_{2 \%}$ demonstrated a capacity retention of $91.57 \%$ at $1 \mathrm{C}$ rate after 150 cycles. The rate capability was also enhanced, as the reversible capacities of 172.3 and $165.7 \mathrm{mAh} \mathrm{g}^{-1}$ were delivered at $5 \mathrm{C}$ and $10 \mathrm{C}$, respectively. $\mathrm{A}$ comparison between the electrochemical properties of $\mathrm{Li}\left[\mathrm{Ni}_{0.89} \mathrm{Co}_{0.05} \mathrm{Mn}_{0.05} \mathrm{Al}_{0.01}\right]_{2}(\mathrm{NCMA}), \mathrm{NCM}$, and NCA with similar Ni contents demonstrated the superior behavior of NCMA [246] (see Figure 10). 
The NCMA delivered a capacity of $228 \mathrm{mAh} \mathrm{g}^{-1}$ at $0.1 \mathrm{C}\left(18 \mathrm{~mA} \mathrm{~g}^{-1}\right)$ at $30^{\circ} \mathrm{C}$. The full cell with a graphite anode demonstrated a capacity retention of $84.5 \%$ after 1000 cycles at $1 \mathrm{C}$. The NCMA even with a small $\mathrm{Al}$ concentration of $1 \mathrm{~mol} \%$ outperformed the NCA and NCM cathodes both in terms of capacity and cycle ability (see Figure 11). The authors also demonstrated that the reason for this remarkable result is due to the fact that the Al-doping prevents the large anisotropic variation of the lattice parameter in the c-direction at the $\mathrm{H} 2 \rightarrow \mathrm{H} 3$ phase transition. This reduced strain for the NCMA cathode results in reduced or lack of microcracks in the secondary particles, at contrast with NCA and NCM. Moreover, the differential scanning calorimetry (DSC) analysis demonstrated an increase of the thermal stability in NCMA, with its exothermic peak temperature at $205{ }^{\circ} \mathrm{C}$ and heat generation of $1384 \mathrm{~J} \mathrm{~g}^{-1}$ (see Figure 12). On another hand, the temperature inducing change to the rock-salt structure accompanies with oxygen loss and is as low as $250^{\circ} \mathrm{C}$ for aged NCA, causing severe safety problems [247].

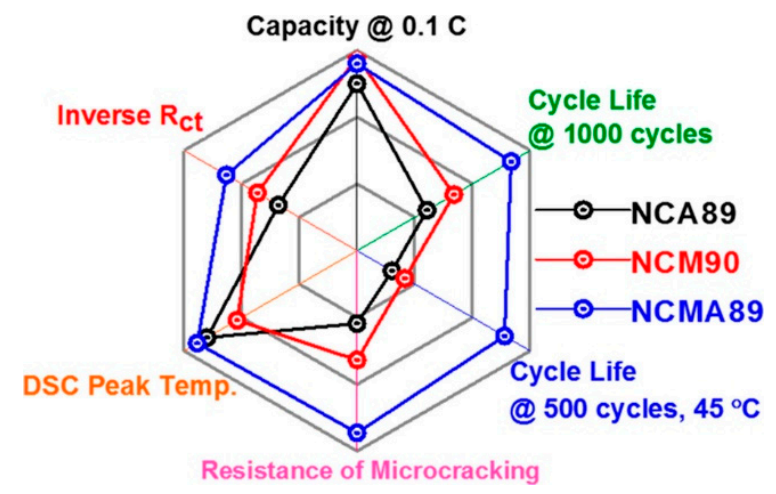

Figure 10. Spider chart of electrochemical performance of $\mathrm{Li}\left[\mathrm{Ni}_{0.89} \mathrm{Co}_{0.05} \mathrm{Mn}_{0.05} \mathrm{Al}_{0.01} \mathrm{O}_{2}\right.$ (NCMA89). Reproduced with permission from [246]. Copyright 2019 The American Chemical Society.

a

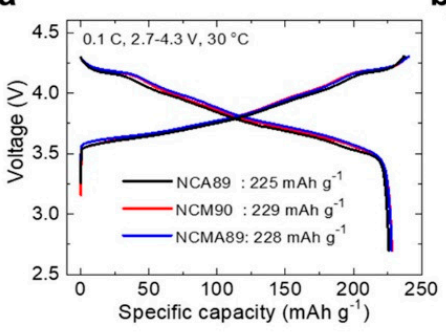

b.

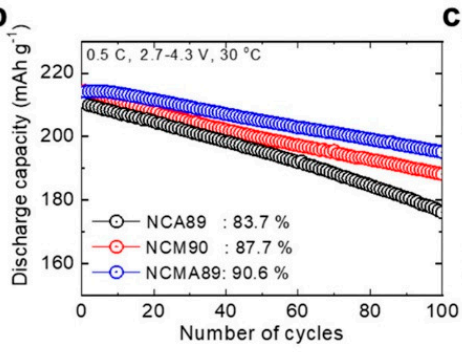

C

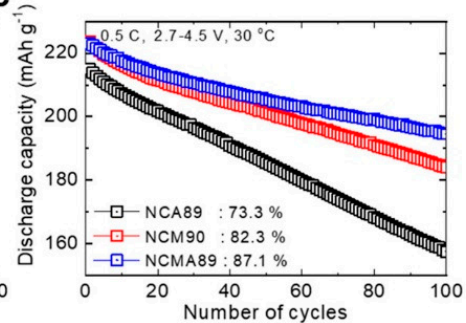

d

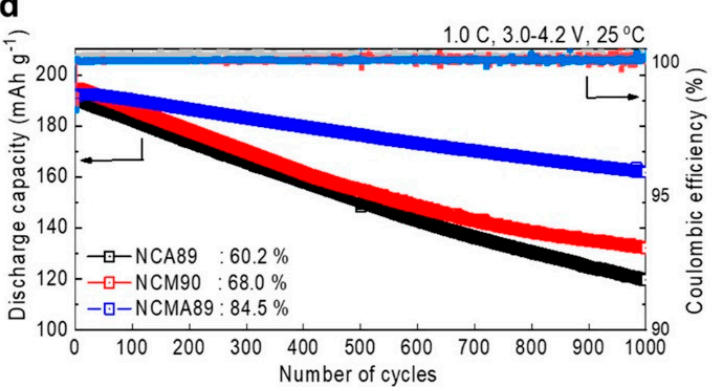

e

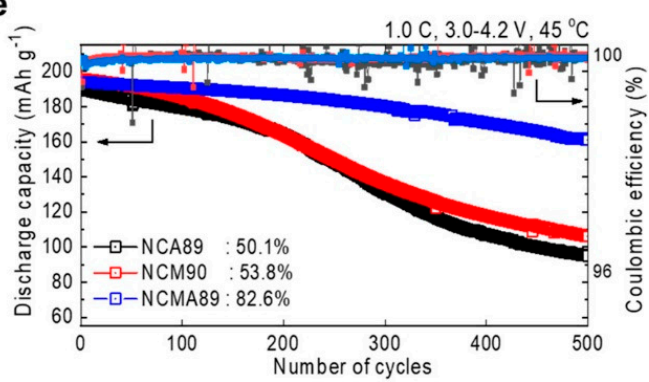

Figure 11. Comparison of electrochemical performance of the NCA89, NCM90, and NCMA89 cathodes in half-cells with Li metal anode. (a) First cycle voltage profiles for the three cathodes at $0.1 \mathrm{C}$ at $30{ }^{\circ} \mathrm{C}$. Cycle ability of the three cathodes were tested in voltage ranges of (b) $2.7-4.3$ and (c) $2.7-4.5 \mathrm{~V}$ at $0.5 \mathrm{C}$ and $30{ }^{\circ} \mathrm{C}$. Long-term cycling performance of the $\mathrm{NCA} 89$, NCM90, and $\mathrm{Li}\left[\mathrm{Ni}_{0.89} \mathrm{Co}_{0.05} \mathrm{Mn}_{0.05} \mathrm{Al}_{0.01}\right]_{2}$ (NCMA89) cathodes using pouch full cells at $1 \mathrm{C}$ and (d) 25 and (e) $45{ }^{\circ} \mathrm{C}$ with a voltage range of 3.0-4.2 V with mesocarbon microbead graphite as an anode. Reproduced with permission from [246]. Copyright 2019 The American Chemical Society. 


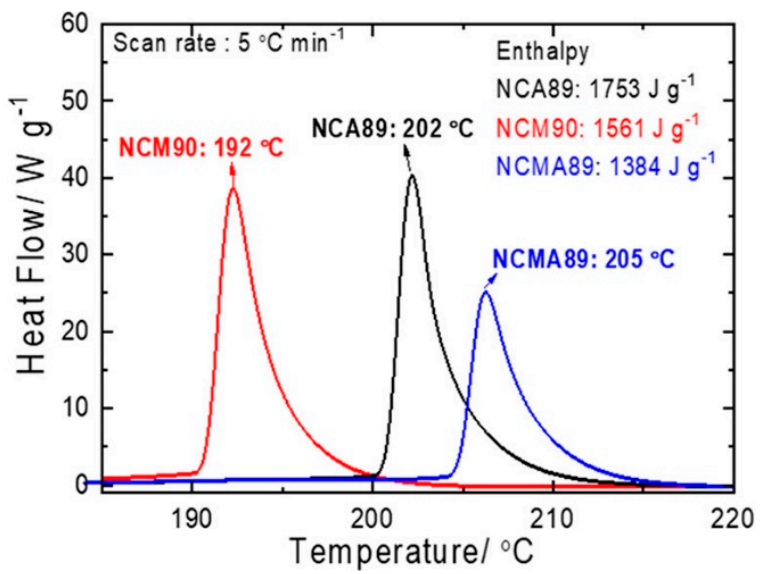

Figure 12. DSC profiles for the NCA89 (i.e., NCA with 0.89 Ni), NCM90, and $\mathrm{Li}\left[\mathrm{Ni}_{0.89} \mathrm{Co}_{0.05} \mathrm{Mn}_{0.05} \mathrm{Al}_{0.01}\right] \mathrm{O}_{2}$ (NCMA89) cathodes measured in their second charged state $\left(\mathrm{Li}_{0.3} \mathrm{MO}_{2}\right)$ in the presence of $1.2 \mathrm{~mol} \mathrm{~L}^{-1} \mathrm{LiPF}_{6} \mathrm{EC}: \mathrm{EMC}=3: 7 \mathrm{by}$ vol. $\%$ with $2 \mathrm{wt}$. $\%$ VC. Reproduced with permission from [246]. Copyright 2019 The American Chemical Society.

Liang et al. performed a DFT calculation to study the doping effects of $\mathrm{Mg}^{2+}, \mathrm{Al}^{3+}, \mathrm{Ti}^{4+}, \mathrm{Zr}^{4+}, \mathrm{Si}^{4+}$, $\mathrm{Ga}^{3+}$, and $\mathrm{V}^{5+}$ and their impact on structural and electrochemical properties (see Figure 13) [248]. As a result, the co-substitution of $\mathrm{Ti}$ or $\mathrm{Zr}$ at $\mathrm{Co}$ sites and $\mathrm{Al}$ at $\mathrm{Mn}$ sites has been proposed as a promising multidoping strategy. DFT calculations also suggested codoping with $\mathrm{Al}$ and $\mathrm{Mg}$ dopants, in which case $\mathrm{Al}$ and $\mathrm{Mg}$ occupy preferentially the $\mathrm{Ni}$ and Li sites, respectively [249]. On another hand, P- and F-codoping of NCM811 was considered by Yuan et al. The corresponding material demonstrated a capacity retention of $94.4 \%\left(162.3 \mathrm{mAh} \mathrm{g}^{-1}\right)$ after 100 cycles at $0.5 \mathrm{C}$ [250].
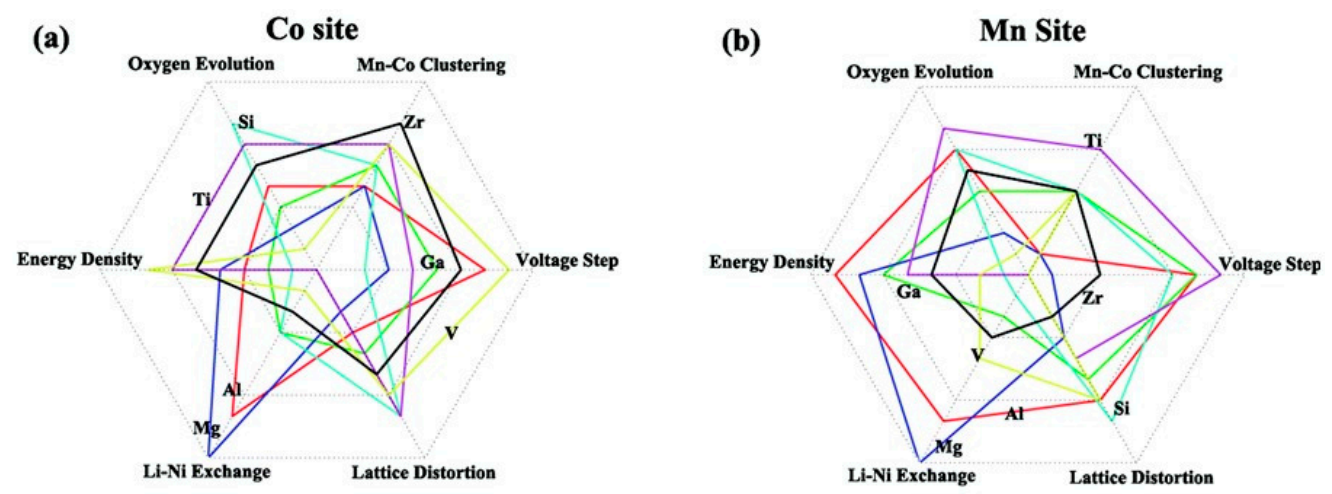

Figure 13. Spider plots of doping impact of each element (at Co and Mn sites) on different electrochemical and structural properties of NCM811. Reproduced with permission from [248]. Copyright 2017 Royal Society of Chemistry.

Liu et al. combined $\mathrm{Cr}$ ionic doping together with surface coating with the fast ion conductor $\mathrm{LiAlO}_{2}$, but only on a Ni-poor 3 wt. $\% \mathrm{LiAlO}_{2}$-coated $\mathrm{Li}_{1.2} \mathrm{Ni}_{0.16} \mathrm{Mn}_{0.56} \mathrm{Cr}_{0.08} \mathrm{O}_{2}$ [251]. Moreover, the good results obtained on NCM with such a small Ni concentration might not extend to the case of NCM, taking into account the higher diffusion of Al in Ni-rich NCM [174]. On another, hand, Xin et al. obtained a Li-Nb-O coated and substituted NCM811 by wet chemistry in a single step treatment [252]. Owing to the synergetic effects of the protective surface coating and doping by $\mathrm{Nb}^{5+}$ incorporation into the bulk structure, the rate capability was improved, with a capacity of $158 \mathrm{mAh} \mathrm{g}^{-1}$ delivered at $2 \mathrm{C})$ as well as the capacity retention ( $89.6 \%$ vs. $81.6 \%$ after 60 cycles). However, without any coating, $\mathrm{Li}$ et al. reported that NCM811 cathode simply doped with 1 at.\% $\mathrm{Nb}$ prepared through a two-step sol-gel method demonstrated a capacity retention of $94.55 \%$ after 100 cycles at $1 \mathrm{C}$, and a good rate capability with a capacity of $151.46 \mathrm{mAh} \mathrm{g}^{-1}$ at $5 \mathrm{C}$ [253]. 
A similar approach consisted in the synthesis of NCM with a gradient-concentration of $\mathrm{La}^{3+}$ and $\mathrm{Y}^{3+}$ rare earth cations. In the first case, a cation-mixed (perovskite phase) layer of $\mathrm{La}_{2} \mathrm{Li}_{0.5} \mathrm{Co}_{0.5} \mathrm{O}_{4}$ was formed at the surface of NCM811, with gradient concentration $\mathrm{La}^{3+}$ inside the particles. As a cathode, it delivered $95.2 \%$ of its initial capacity after 100 cycles at $1 \mathrm{C}$ [254]. In the case if yttrium, a $\mathrm{Y}_{2} \mathrm{O}_{3}$ surface layer was formed with gradient concentration $\mathrm{Y}^{3+}$ inside the particles. The $2 \mathrm{~mol} \%$ Y-modified sample demonstrated a capacity retention of $98.4 \%$ after 100 cycles $(0.5 \mathrm{C}$ rate, $2.8-4.5$ V) [255]. Wu et al. modified the surface of NCM811 with the perovskite-like $\mathrm{La}_{2} \mathrm{Ni}_{0.5} \mathrm{Li}_{0.5} \mathrm{O}_{4}$ [256]. In addition, during the high-temperature synthesis process, $\mathrm{La}^{3+}$ ions are also doped into the subsurface lattice of NCM811, so the final product combined synergetic effects of doping and coating. As a result, when cycled in the range $2.75-4.5 \mathrm{~V}$, the first discharge capacity at $0.2 \mathrm{C}$ of the La-modified sample is $229.3 \mathrm{mAh} \mathrm{g}^{-1}$ and the 200th capacity retention ratio at $1 \mathrm{C}$ has been improved from $63.7 \%$ to $90.1 \%$. The electronic properties of selected doped-NCM materials are reported in Table 4 .

Table 4. Electrochemical properties of selected doped NMC811 (except Al concentration gradient $\mathrm{LiNi}_{0.76} \mathrm{Co}_{0.09} \mathrm{Mn}_{0.15} \mathrm{O}_{2}$ [242] and $\mathrm{LiNi}_{0.7} \mathrm{Co}_{0.15} \mathrm{Mn}_{0.15} \mathrm{O}_{2}$ [243]) cathode materials ( $\mathrm{CR}=$ capacity retention).

\begin{tabular}{|c|c|c|}
\hline Dopant & Electrochemical Properties & \\
\hline $\mathrm{Zr}$ & $\begin{array}{c}172 \mathrm{mAh} \mathrm{g}^{-1} \text { at } 1 \mathrm{C} ; \mathrm{Cr} \text { of } 83.2 \% \text { after } 200 \text { cycles at } 1 \mathrm{C} \\
(2.8-4.5 \mathrm{~V})\end{array}$ & [229] \\
\hline $\mathrm{Ti}$ & $\begin{array}{l}165.02 \mathrm{mAh} \mathrm{g}^{-1} \text { at } 1 \mathrm{C} ; \mathrm{CR} \text { of } 77.01 \% \text { after } 150 \text { cycles at } 1 \\
\text { C }(2.8-4.3 \mathrm{~V})\end{array}$ & [233] \\
\hline $\mathrm{Ti}$ & $\begin{array}{c}160.6 \mathrm{mAh} \mathrm{g}^{-1} \text { after } 200 \text { cycles at } 1 \mathrm{C} ; \mathrm{CR} \text { of } 95.03 \% \\
(2.8-4.3 \mathrm{~V})\end{array}$ & [234] \\
\hline $\mathrm{Al}$ & $\begin{array}{c}154 \mathrm{mAh} \mathrm{g}^{-1} \text { after } 200 \text { cycles at } 1 \mathrm{C} ; \mathrm{CR} \text { of } 85.32 \% \\
(2.8-4.3 \mathrm{~V})\end{array}$ & [234] \\
\hline $\mathrm{Mg}$ & $\begin{array}{c}147 \mathrm{mAh} \mathrm{g}^{-1} \text { after } 200 \text { cycles at } 1 \mathrm{C} ; \mathrm{CR} \text { of } 82.07 \% \\
(2.8-4.3 \mathrm{~V})\end{array}$ & [234] \\
\hline $\mathrm{Al}$ & $\begin{array}{l}171.71 \mathrm{~mA} \mathrm{~h} \mathrm{~g}^{-1} \text { at } 1 \mathrm{C} ; \mathrm{CR} \text { of } 96.15 \% \text { after } 100 \text { cycles at } 1 \\
\mathrm{C}(3.0-4.3 \mathrm{~V})\end{array}$ & [240] \\
\hline Al-doped gradient & $\begin{array}{c}203 \mathrm{mAh} \mathrm{g}^{-1} \text { at } 0.5 \mathrm{C} ; \mathrm{CR} \text { of } 95 \% \text { after } 100 \text { cycles at } 0.5 \mathrm{C} \\
\text { CR of } 95 \% \text { after } 1000 \text { cycles at } 1 \mathrm{C} \text { in full cell (graphite } \\
\text { anode) }(3.0-4.2 \mathrm{~V})\end{array}$ & [242] \\
\hline Al-doped gradient & $\begin{array}{c}213.6 \mathrm{mAh} \mathrm{g}^{-1} \text { at } 0.1 \mathrm{C} ; \mathrm{Cr} \text { of } 89.5 \% \text { after } 200 \text { cycles at } \\
0.1 \mathrm{C}(3.0-4.5 \mathrm{~V}) \\
145 \mathrm{mAh} \mathrm{g}^{-1} \text { at } 10 \mathrm{C}\end{array}$ & [243] \\
\hline $\begin{array}{l}\text { P and F } \\
\text { codoping }\end{array}$ & $\begin{aligned} 162.3 \mathrm{mAh} \mathrm{g}^{-1} \text { after } 100 \text { cycles at } 0.5 \mathrm{C}, \mathrm{CR} \text { of } 94.4 \% \\
(3.0-4.3 \mathrm{~V})\end{aligned}$ & {$[250]$} \\
\hline Y & $\begin{array}{l}189.4 \mathrm{mAh} \mathrm{g}^{-1} \text { at } 0.5 \mathrm{C} ; \mathrm{CR} \text { of } 98.4 \% \text { after } 100 \text { cycles at } \\
0.5 \mathrm{C}(2.8-4.5 \mathrm{~V})\end{array}$ & [255] \\
\hline $\mathrm{La}$ & $\begin{array}{c}192 \mathrm{mAh} \mathrm{g}^{-1} \text { at } 1 \mathrm{C} ; \mathrm{CR} \text { of } 90.1 \% \text { after } 200 \text { cycles } \\
(2.75-4.5 \mathrm{~V})\end{array}$ & [256] \\
\hline
\end{tabular}

\subsubsection{Optimization of the Electrolyte}

Unstable cathode-electrolyte interface (CEI) degrades the electrochemical properties of NCM cathodes at high voltages. The different mechanisms responsible for this instability (surface phase transitions, cracking, Ni dissolution, electrolyte decomposition, oxygen release) have been reviewed elsewhere [257]. The formation of the (CEI) could enter in the section devoted to the coating. However, the approach which consists in optimizing the CEI via the appropriate choice of the electrolyte is different. In addition, the recent progress obtained by the choice of electrolyte to optimize the CEI justifies a separate section. Conventional flammable organic liquid electrolytes that are used in all the 
works reported in this review are typically composed of $1 \mathrm{~mol} \mathrm{~L}^{-1} \mathrm{LiPF}_{6}$ salt in ethylene carbonate (EC) and linear carbonate(s), for instance ethyl methyl carbonate (EMC). Different additives have been considered to adapt the electrolyte to the high operating voltage of NMC811 and minimize undesired reaction at the interface. The efforts to control the CEI of NCM811 have been reviewed in [258] and we refer to this former review for additives prior to 2019.

Different attempts have been made to find electrolyte additives that would stabilize the surface of NCM materials. They have been reviewed in [259]. More recently, a functional vinyl $-\mathrm{C}=\mathrm{C}-$ group allylboronic acid pinacol ester (ABAPE) was introduced as a film forming additive [260].

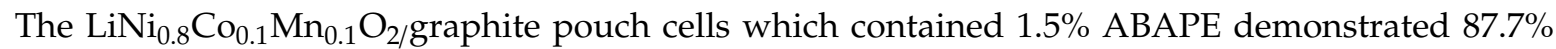
capacity retention compared with $71.8 \%$ of blank electrolyte after 500 cycles. This improvement is due to the oxidization of ABAPE prior to blank electrolyte on the cathode, which prevents the electrolyte decomposition, and results in the formation of a protective surface layer. 4, 5-difluoro-1, 3-dioxolan-2-one (DFEC) was reported as a film forming additive to enhance the electrochemical performance of $\mathrm{LiNi}_{0.8} \mathrm{Co}_{0.1} \mathrm{Mn}_{0.1} \mathrm{O}_{2} / / \mathrm{SiO} @ \mathrm{C}$ full cells [261]. The cells with $2 \%$ DFEC keep the best capacity retention of $88.7 \%$ after 500 cycles comparing to $83.9 \%$ of blank group. Note, however, that this additive had no significant effect on NCA, the improvement being attributed to the formation of the film on the anode side, not on the cathode. Thioether-substituted diaminocyclopropenium redox-reactive cation was proposed as an electrolyte additive by Ji et al. [262]. This organic cation demonstrated an electrochemical reversibility at $\approx 4.55 \mathrm{~V}$ vs. $\mathrm{Li}^{+} / \mathrm{Li}$ and solubility $(0.5 \mathrm{M})$ in carbonate-based electrolyte. With $0.2 \mathrm{M}$ addition, the $\mathrm{LiNi}_{0.8} \mathrm{Co}_{0.1} \mathrm{Mn}_{0.1} \mathrm{O}_{2 /} /$ graphite cell survived 54 cycles at $0.2 \mathrm{C}$ with $100 \%$ overcharge. It also supported an utmost $4.4 \mathrm{~mA} \mathrm{~cm}^{-2}(2 \mathrm{C})$ with $100 \%$ overcharge and delivered a maximum capacity of $7540 \%$ SOC at 0.2 C. Peng et al. developed a highly concentrated acetonitrile (AN)-based electrolyte with a vinylene carbonate (VC) additive. The VC leads to the formation of a polycarbonate-based SEI that minimizes Li corrosion, which results in a very high Li CE of 99.2\% at $0.2 \mathrm{~mA} \mathrm{~cm}^{-2}$ [263]. Stable cycling of Li|AN-electrolyte + VC|NCM622 cells with a high cathode loading of $4 \mathrm{mAh} \mathrm{cm}^{-2}$ was demonstrated, but it was not tested with NCM811, yet. Among the new performing additives, we can mention 4,5-Dicyano-1,3-dithiol-2-one (DDO), as 0.1 wt.\% DDO in the electrolyte raised the capacity retention of NCM811 to $75.59 \%$ after 200 cycles, against $15.11 \%$ only for the blank electrolyte [264]. Kong et al. chose sulfolane to be oxidized in advance and built a protective film around NCM811. Moreover, they employed fluoroethylene carbonate to be reduced prior and form a film on the face of silicon oxide-graphite negative electrode. The full $\mathrm{NCM} 811 / / \mathrm{SiO}_{\mathrm{x}}$-graphite anode with this modified electrolyte demonstrated a capacity retention of $77.51 \%$ after 200 cycles with upper voltage at $4.5 \mathrm{~V}$ [265]. With $0.5 \mathrm{wt}$ \% $\%$,O-bis(trimethylsilyl)acetamide (BSA) additive, NCM811 demonstrated improved capacity retention of $86 \%$ after 200 cycles at $1 \mathrm{C}$, while it shows only $69.4 \%$ with the baseline electrolyte [266]. Another film-forming electrolyte additive is 2,4,6-triphenyl boroxine (TPBX), which increased the capacity of NCM811 from 57\% to $78 \%$ after 200 cycles at $1 \mathrm{C}$ in a half-cell [267]. The performance of the graphite//NCM811 full cell was also improved importantly with this additive in the electrolyte, because the TPBX is also reduced earlier than the ethylene carbonate and forms on the graphite anode a conductive SEI. A similar benefit for both the NCM cathode and graphite anode was demonstrated with phenyl trans-styryl sulfone additive [268]. Tris(trimethylsilyl) phosphite (TMSPi) was introduced as an electrolyte additive and improved the electrochemical performance of the NMC811/Si-Gr full cells through formation of protective surface layers at the electrode/electrolyte interfaces [269]. However, the cycle ability has been tested on 50 cycles only.

Remarkable results were reported with $\mathrm{LiNi}_{0.76} \mathrm{Mn}_{0.14} \mathrm{Co}_{0.10} \mathrm{O}_{2}$, an $\mathrm{NCM}$ with composition close to that of NCM811, owing to an optimized electrolyte $\left(0.6 \mathrm{~mol} \mathrm{\textrm {L } ^ { - 1 }}\right.$ lithium bis(trifluoromethanesulfonyl)imide $+0.4 \mathrm{~mol} \mathrm{~L}^{-1}$ lithium bis(oxalato)borate $+0.05 \mathrm{~mol} \mathrm{~L}^{-1} \mathrm{LiPF}_{6}$ dissolved in ethylene carbonate and ethyl methyl carbonate (4:6 by weight)) [270]. Excellent stability at a high charge cutoff voltage of $4.5 \mathrm{~V}$ was demonstrated in a cell with lithium metal anode, with a discharge capacity larger than $220 \mathrm{mAh} \mathrm{g}^{-1}\left(846 \mathrm{Wh} \mathrm{kg}^{-1}\right)$ and capacity retention higher than $80 \%$ capacity after 1000 cycles at $2 \mathrm{C}$ rate. 
A new class of nonflammable organic liquid electrolyte has been recently proposed, consisting in $1 \mathrm{~mol} \mathrm{~L}^{-1} \mathrm{LiPF}_{6}$ in propylene carbonate (PC) and fluorinated linear carbonate(s) [271]. The substitution of a flammable electrolyte by a nonflammable electrolyte has the first obvious advantage to improve importantly the safety of the battery, especially as the Li-ion batteries on Ni-rich cathodes are subject to battery fires [64]. However, these new electrolytes also proved to improve importantly the performance of these cathodes. The pristine NCM811 combined with the electrolyte composed of $1 \mathrm{~mol} \mathrm{~L}^{-1}$ $\mathrm{LiPF}_{6} / \mathrm{PC} /$ methyl(2,2,2-trifluoroethyl) carbonate (FEMC)/di-(2,2,2 trifluoroethyl)carbonate (DFDEC) demonstrated remarkable electrochemical properties [272]. Under the high charge cutoff voltage of $4.5 \mathrm{~V}$, the NCM811 in a half cell with this electrolyte demonstrated a capacity of $230 \mathrm{mAh} \mathrm{g}^{-1}$ with retention of $95 \%$ after 100 cycles at 0.2 C. Due to the interfacial incompatibility between PC and graphite, this electrolyte cannot be used with a full cell equipped of a graphite anode. In this case, $1 \mathrm{wt} . \%$ vinylene carbonate (VC) was added to the electrolyte, as a SEI-forming electrolyte additive for graphite anode, which did not change the nonflammable properties [273]. With this SEI-forming additive, the NCM 811 in graphite//NCM811 full cells delivered $250 \mathrm{mAh} \mathrm{g}^{-1}$ at $0.2 \mathrm{C}$ with $82 \%$ retention after 50 cycles. In this work, the authors also visually proved reduced crack formation and metal-dissolution via electron microscopy analysis. Therefore, even though initial formation of cracks comes from structural stress $[66,159,274,275]$, their development with cycling can be significantly reduced and controlled with the use of a functional electrolyte that stabilizes the CEI. Note the choice of the VC additive chosen by Pham et al. may not be the best choice, since Qiu et al. demonstrated that diphenyl or methylphenyl carbonate outperforms vinylene carbonate as additives of electrolyte in NMC811//graphite cells [276]. $\mathrm{Li}$ et al. reported that the cycle life of $\mathrm{LiNi}_{0.94} \mathrm{Co}_{0.06} \mathrm{O}_{2}$ is greatly extended when lithium bis(oxalate) (LiBOB) is added in the electrolyte [277], but no test with NMC811 has been made, yet. On another hand, the addition of only $0.5 \mathrm{wt}$.\% triphenylphosphine oxide (TPPO) into a standard electrolyte $\left(\mathrm{LiPF}_{6}\right.$ in EC:EMC 3:7 by weight) increased the first cycle Coulombic efficiency and the reversible specific capacity; it also improved the capacity retention of the NMC811//graphite cell cycled between 2.8 and $4.3 \mathrm{~V}$ [278]. After 100 cycles at $0.5 \mathrm{C}$, the capacity was still $172 \mathrm{mAh} \mathrm{g}^{-1}$, corresponding to a capacity retention of $92 \%$. Jo et al. determined that monobasic sodium phosphate $\left(\mathrm{NaH}_{2} \mathrm{PO}_{4}\right)(\mathrm{P} 2)$ additive improves the thermal stability of NCM811 not only by the formation of a conductive CEI, but also because it decelerates the formation of NiO-phase on the cathode by controlling the hydrofluoric acid content [279].

An NMC811-based all-solid-state lithium battery (ASSLB) using sulfide electrolyte was fabricated by $\mathrm{Li}$ et al. [280]. The NMC811 was first coated with $\mathrm{LiCoO}_{2}$ to form core-shell NCM-LCO via coprecipitation method. Then, NCM@LCO material with Ni-poor surface was obtained via high temperature solid phase method. Finally, the NCM@LCO particles were coated with $\mathrm{LiNbO}_{3}$ via a wet coating method to obtain the cathode material, which demonstrated a capacity retention of $80 \%$ after 585 cycles at $0.612 \mathrm{~mA} \mathrm{~cm}^{-2}$. Recently, Cui et al. [281] selected methyl diphenylphosphonate (MDPO) as additive, which widened the electrochemical window up to $5.0 \mathrm{~V}$ and stabilized the coulombic efficiency of the NCM811 cathode. Furthermore, MDPO plays an important role for the thermal stability of the cell.

Mao et al. proposed to replace $\mathrm{LiPF}_{6}$ by lithium difluoro(oxalato)borate (LiDFOB) salt [282]. Owing to the decomposition reaction of LiDFOB, the in-situ hierarchical CEI presents a two-layered structure, where the inner layer is rich in $\mathrm{LiF}$ and outer layer mainly contains organic components such as $\mathrm{Li}_{x} \mathrm{BO}_{\mathrm{y}} \mathrm{F}_{\mathrm{z}}$. With the LiDFOB based electrolyte, The NCM811//Li cell delivered a capacity of $127.5 \mathrm{mAh} \mathrm{g}^{-1}$ at $10 \mathrm{C}$, with capacity retention of $69.8 \%$ after 400 cycles $\left(17.1 \%\right.$ with the $\mathrm{LiPF}_{6}$-based electrolyte).

\subsubsection{Aqueous Processing}

Aqueous electrode processing has advantages. Manufacturing costs are lower compared to traditional processing using $N$-methylpyrrolidone (NMP). In addition, overexposure to NMP is dangerous for health. Therefore, aqueous process also offers environmental benefits [283-285]. Water 
soluble binders also facilitate LIB recycling. For these reasons, water-based processing is widely used for graphite anodes. On another hand, it is difficult to adopt this process for cathodes, due to adverse effects of water on NCM materials of different compositions [286-289]. In particular, transition metal oxides produce basic solutions in water [290-293]. In particular, the exposure of NCM811 to humidity results in the formation of surface impurities and decomposition of the surface layers and these effects are correlated with nickel content [294-296]. On the other hand, Xiong et al. reported that NCM811 water exposure reduces the capacity, but decreased the capacity fade, and increased the structural stability [297]. Recently, Wood et al. reported a systematic investigation of the water stability of four different NCM cathode powders with varying nickel contents, including NCM811 [298]. Pouch cells made with aqueous-processed NMC 811 cathodes showed $70 \%$ capacity retention through 1000 cycles at $\mathrm{C} / 3$ rate. The carboxymethylcellulose/acrylic emulsion binder used instead of the standard polyvinylidene difluoride (PVDF) binder resulted in a lower rate capability above $1 \mathrm{C}$ current rate. NMC 811 only showed $3 \mathrm{wt} \% \mathrm{Li}^{+}$dissolution under typical processing conditions, and yet the observed $\mathrm{Li}^{+}$leaching did not correspond to a lower initial capacity. This work then opens the route to implementation of aqueous processing of Ni-rich NMC in future battery production lines, which will enable higher cell energy densities at lower cost.

\section{The Route to Co-Free Ni-Rich Batteries}

We have reported the state-of-the-art of Ni-rich NCA, NCM with the Ni composition $x=0.8$, which is the highest concentration commercialized today. It does not mean that the fabrication of Li-ion batteries with larger $\mathrm{Ni}$ concentrations is hopeless. As reported in this review, full-gradient and core-shell structured cathode particles opened the route to average compositions with a x-concentration larger than 0.8. Attempts have even be made to use this technique to synthesize Co-free electrodes. A Co-free precursor with a $16 \mu \mathrm{m} \mathrm{Ni}(\mathrm{OH})_{2}$ core and $1 \mu \mathrm{m} \mathrm{Ni} \mathrm{N}_{0.8} \mathrm{Mn}_{0.2}(\mathrm{OH})_{2}$ shell was reacted with $\mathrm{LiOH} . \mathrm{H}_{2} \mathrm{O}$ at $750{ }^{\circ} \mathrm{C}$ to obtain retain a well-defined core-shell structured material. As a cathode, it exhibited higher specific capacity than NMC811, while the cycling performance was equivalent to NMC811 [299]. A cost-effective cobalt-free $\mathrm{LiNi}_{0.9} \mathrm{Mn}_{0.1} \mathrm{O}_{2}$ was also synthesized by using a coprecipitation method; as a cathode, it delivered capacity of $190 \mathrm{mAhg}^{-1}$ in the first cycle at a rate of $0.2 \mathrm{C}$, and a capacity retention of $93 \%$ over 150 cycles at 2.7-4.3 V [300]. Particles with a $\mathrm{Li}\left[\mathrm{Ni}_{0.94} \mathrm{Co}_{0.038} \mathrm{Mn}_{0.022}\right] \mathrm{O}_{2}$ core and a $1.5 \mu \mathrm{m}$ thick concentration gradient (CG) shell with the outermost surface composition $\mathrm{Li}\left[\mathrm{Ni}_{0.841} \mathrm{Co}_{0.077} \mathrm{Mn}_{0.082}\right]_{2}$ was fabricated by differential coprecipitation process [301]. The average composition was then $\mathrm{Li}\left[\mathrm{Ni}_{0.9} \mathrm{Co}_{0.05} \mathrm{Mn}_{0.05}\right] \mathrm{O}_{2,}$, reducing the Co content to a residual concentration. The radial texturing of the shell layer, which is specific to the core-shell and gradient concentration process, protracts the detrimental $\mathrm{H} 2 \rightarrow \mathrm{H} 3$ phase transition responsible for the microcracking. As a consequence, this compositionally partitioned $\mathrm{Li}\left[\mathrm{Ni}_{0.9} \mathrm{Co}_{0.05} \mathrm{Mn}_{0.05}\right]_{\mathrm{O}_{2}}$ cathode delivered a capacity of $229 \mathrm{mAh} \mathrm{g}^{-1}$ and exhibited $88 \%$ capacity retention after 1000 cycles in a full cell. The concepts of core-shell, concentration gradient two-sloped full-concentration gradient cathodes are then very promising to increase the electrochemical performance of LIBs based on Ni-rich cathodes. Moreover, the process used to synthesize CS and CG precursors for subsequent target production is coprecipitation because of the unique growth mechanism of spherical particles. Actually, the coprecipitation reaction proved to be very efficient to fabricate spherical high-tap density precursors at the industrial level [302]. These authors argued that it is greatly tough to manufacture in multiple identical copies CG cathodes for large-scale usage. On another hand, the fabrication of the CS structure is much easier. The main difficulty is the high cost due to the batch-wise system. Nevertheless, all these problems found a solution, since the South Korean cathode manufacturer EcoPro BM commercialized already NMC811 with the concentration-gradient process, and SK Innovation (trade mark) will develop this year with EcoPro BM such an NMC811-based cathode to which will be added a separator to improve the stability [303]. Still, however, high-capacity Co-free electrodes with a cycling life the order of 1000 cycles required for industrial development is still to be demonstrated, but hopefully, it should be demonstrated within few years. 
The various coatings, doping strategies, electrolyte enhancement that we have reviewed did improve the electrochemical performance. The difficulty is to find one of them that can solve all the problems simultaneously. For instance, conductive coating improves the safety and rate capability by facilitating the $\mathrm{Li}^{+}$diffusivity, but often fails to improve the mechanical problems responsible for the microcracking of the particles. One solution has been found with $\mathrm{TiP}_{2} \mathrm{O}_{7}$-coated NCA as a cathode in a full cell was able to perform more than 2200 cycles at $25^{\circ} \mathrm{C}$ and more than 1000 cycles at $45^{\circ} \mathrm{C}$ before the capacity retention fading to $80 \%$ [111]. Doping improves the structural stability of the material. The best result was obtained with Al-doping, which was able to suppress the microcrack nucleation and propagation in $\mathrm{Li}\left[\mathrm{Ni}_{0.89} \mathrm{Co}_{0.05} \mathrm{Mn}_{0.05} \mathrm{Al}_{0.01}\right] \mathrm{O}_{2}$. In a full cell with graphite anode it was able to deliver a high capacity with $84.5 \%$ after 1000 cycles at $1 \mathrm{C}$ [246]. Even at $45^{\circ} \mathrm{C}$, the cycle life was 500 cycles. This material is a hybrid of NCA and NCM. It is very difficult to increase the cycle life up to 1000 cycles with NCM811 alone. It can be used, however, in a core-shell structure of spherical particles designed to a $\mathrm{LiNiO} 2$ core and a $0.5 \mu \mathrm{m}$-thick NCM811 encapsulating shell, which fulfilled this goal [214]. As recalled above, the radial texturing was essential to achieve the outstanding performance of the compositionally partitioned $\mathrm{Li}\left[\mathrm{Ni}_{0.9} \mathrm{Co}_{0.05} \mathrm{Mn}_{0.05} \mathrm{O}_{2}\right.$ material. This is the motivation to synthesize a new class of Ni-rich NMC and NCA with a modified microstructure similar to the texture met in gradient concentration and core-shell processes. This can be achieved by doping with boron [304]. Boron-doped at the level of $1 \mathrm{~mol} \% \mathrm{Li}\left[\mathrm{Ni}_{0.9} \mathrm{Co}_{0.05} \mathrm{Mn}_{0.05}\right] \mathrm{O}_{2}$ obtained by the addition of $\mathrm{B}_{2} \mathrm{O}_{3}$ during the lithiation of the hydroxide precursor has a highly textured microstructure similar to that of gradient cathodes [304]. This cathode delivered a capacity of $237 \mathrm{mAh} \mathrm{g}^{-1}$ at $4.3 \mathrm{~V}$, and demonstrated a remarkable capacity retention of $91 \%$ after 100 cycles at $55^{\circ} \mathrm{C}$. The performance is still outperformed by the compositionally partitioned material with the same average composition, but is much better than the un-doped $\mathrm{Li}\left[\mathrm{Ni}_{0.9} \mathrm{Co}_{0.05} \mathrm{Mn}_{0.05}\right] \mathrm{O}_{2}$. Microstructure modified cathodes were obtained by doping with aluminum $[245,305]$. The capacity retention of the homogeneous $2 \%$ molar weight $\mathrm{Al}^{3+}$ doped $\mathrm{LiNi}_{0.88} \mathrm{Co}_{0.095} \mathrm{Mn}_{0.025} \mathrm{O}_{2}$ was raised to $91.57 \%$ at $1 \mathrm{C}$ rate after 150 cycle, owing to the radial arrangement of primary grains. The last example is tungsten-doping [306], also differing from the usual coating in that the primary crystallites keeps the coherency of the secondary particle. In this work, Ryu et al. substituted $\mathrm{W}$ for $\mathrm{Al}$ in NCA to produce $\mathrm{Li}\left[\mathrm{Ni}_{0.9} \mathrm{Co}_{0.09} \mathrm{~W}_{0.01}\right] \mathrm{O}_{2}$ (NCW90), which had two benefits: (i) the presence of microfractures absorbing the strain field caused by the $\mathrm{H} 2 \rightarrow \mathrm{H} 3$ phase transition; (ii) reduced primary particle size, which restricts the concentration of grain boundaries where microcracks nucleate, and facilitates the accommodation of the volume change during cycling. As a consequence, this cathode delivered a capacity of $231.2 \mathrm{mAh} \mathrm{g}^{-1}$ at $0.1 \mathrm{C}$, with capacity retention of $92 \%$ after 1000 cycles.

\section{Conclusions}

NCA, NCM, NCMA cathode materials with Ni concentrations of $80 \%$ already reach the commercial step. We have reviewed the efforts in research, and solutions that have been found to reduce the concentration of antisite defects, to mitigate the side reactions ( $\mathrm{Ni}^{4+}$ oxidizing electrolyte, Co dissolution) and surface reconstructions, and to extend the voltage range up to $4.5 \mathrm{~V}$. The knowledge acquired in the optimization of these materials opens the route to the rapid industrial development of even $\mathrm{Ni}$-richer compounds with reduced concentration of cobalt. We have already warned repeatedly the need to decrease as much as possible the concentration of cobalt in the batteries, not only because Co is toxic and expensive, but also because the conditions of extraction are repeatedly denounced by Amnesty International and the International NGOs [64]. The decrease of Co concentration and ultimately Co-free cathodes with these lamellar compounds will not necessarily reduce the cost of the batteries, because the cost of fabrication of the particles with the appropriate structure and the control of the synthesis parameters will be high, but the electrochemical performance in energy density will be greatly improved, and will respond to the demand for specific applications such as electric cars when extended driving range is needed. 
The weakness of the high-Ni batteries remains their poor thermal stability and severe thermal runaway [307], even though the modifications we have reviewed in the present work improve the situation. The security of these batteries will thus rely still for years to come on a sophisticated battery monitoring system (BMS). We have also pointed out how important it is to investigate the stability of the cells at elevated temperature at $50-60{ }^{\circ} \mathrm{C}$, needed for practical use. Elevated temperature usually improves the capacity and rate capability, but affects the cycle ability. Now that the state-of-the-art in these materials reach the performance needed for commercial use, the report of the electrochemical properties should be more systematic in on-going publications. Attention should also be paid to the pellet density. In most cases, the electrochemical properties of the Ni-rich cathodes have been reported in the case of the low electrode density $\left(\leq 3.4 \mathrm{~g} \mathrm{~cm}^{-3}\right)$ and loading level $\left(<8 \mathrm{mg} \mathrm{cm}^{-2}\right)$, although recent works report active material loading mass of $\approx 11 \mathrm{mg} \mathrm{cm}^{-2}$ [308]. Moreover, as the nickel concentration increased, the commercially available electrode density decreased because of the collapse of the secondary particle during electrode pressing process. Kim et al. pointed out that this could give rise to a large gap between academic research and practical application of the nickel-rich cathode materials [309]. They concluded that the collaborative efforts between the academics and the industrial fields should be expanded.

The present review also reveals that most of the publications reporting advances in the fabrication of performing Ni-rich-based batteries only consider one aspect: either a modification of the cathode particles or the effect of an additive in the electrolyte; a minority of the publications investigate the synergetic effect of multidoping, or doping plus surface modification, and rarely the synergetic effect of modification of the particles and the optimized electrolytes. At this stage, it should then be very useful to investigate such synergetic effects if only to verify their compatibility. Additionally, most of the full cells that have been investigated use the standard graphite anode, while there are now more performing anodes mixing graphite and $\mathrm{SiO}_{x}$ [310]. More collaborations between research teams over the world need to be forged to compare knowledge and add skills related to these different elements of the batteries, considering the urgency to find sustainable ways to store the $10^{12} \mathrm{kWh} / \mathrm{yr}$ that is needed for mankind.

Author Contributions: Conceptualization, C.M.J. and A.M.; writing-review and editing, A.M. and C.M.J. All authors have read and agreed to the published version of the manuscript.

Funding: This research received no external funding.

Conflicts of Interest: The authors declare no conflict of interest.

\section{References}

1. Zhang, H.; Li, C.; Eshetu, G.G.; Laruelle, S.; Grugeon, S.; Zaghib, K.; Julien, C.M.; Mauger, A.; Guyomard, D.; Rojo, T.; et al. From solid solution electrodes and the rocking-chair concept to today's batteries. Angew. Chem. Inter. Ed. 2020, 132, 542-546. [CrossRef]

2. Wang, L.; Chen, B.; Ma, J.; Cui, G.; Chen, L. Reviving lithium cobalt oxide-based lithium secondary batteries-toward a higher energy density. Chem. Soc. Rev. 2018, 47, 6505-6602. [CrossRef]

3. Julien, C.M.; Mauger, A.; Vijh, A.; Zaghib, K. Lithium Batteries: Science and Technology; Springer: Cham, Switzerland, 2016.

4. Okubo, M.; Hosono, E.; Kim, J.; Enomoto, M.; Kojima, N.; Kudo, T.; Zhou, H.; Honma, I. Nanosize effect on high-rate Li-ion intercalation in $\mathrm{LiCoO}_{2}$ electrode. J. Am. Chem. Soc. 2007, 129, 7444-7452. [CrossRef]

5. European Union. Regulation (Eu) No 333/2014 of the European Parliament and of the Council of 11 March 2014 Amending Regulation (Ec) No 443/2009 to Define the Modalities for Reaching the 2020 Target to Reduce Co 2 Emissions from New Passenger Cars. Off. J. Eur. Union 2020, 103, 15-21.

6. Lee, S.H.; Yoon, C.S.; Amine, K.; Sun, Y.K. Improvement of long-term cycling performance of $\mathrm{Li}\left(\mathrm{Ni}_{0.80} \mathrm{Co}_{0.15} \mathrm{Al}_{0.05}\right) \mathrm{O}_{2}$ by $\mathrm{AlF}_{3}$ coating. J. Power Sources 2013, 234, 201-207. [CrossRef]

7. Etacheri, V.; Marom, R.; Elazari, R.; Salitra, G.; Aurbach, D. Challenges in the development of advanced Li-ion batteries: A review. Energy Environ. Sci. 2011, 4, 3243-3262. [CrossRef] 
8. Myung, S.-T.; Maglia, F.; Park, K.-J.; Yoon, C.S.; Lamp, P.; Kim, S.-J.; Sun, Y.-K. Nickel-Rich layered cathode materials for automotive Lithium-ion batteries: Achievements and perspectives. ACS Energy Lett. 2016, 2, 196-223. [CrossRef]

9. Ohzuku, T.; Yoshinari, M. Layered lithium insertion material of $\mathrm{LiCo}_{1 / 3} \mathrm{Ni}_{1 / 3} \mathrm{Mn}_{1 / 3} \mathrm{O}_{2}$ lithium-ion batteries. Chem. Lett. 2001, 30, 642-643. [CrossRef]

10. Yabuuchi, N.; Ohzuku, T. Novel lithium insertion material of $\mathrm{LiCo}_{1 / 3} \mathrm{Ni}_{1 / 3} \mathrm{Mn}_{1 / 3} \mathrm{O}_{2}$ for advanced lithium-ion batteries. J. Power Sources 2003, 119, 171-174. [CrossRef]

11. Lu, Z.; MacNeil, D.D.; Dahn, J.R. Layered $\mathrm{Li}\left[\mathrm{Ni}_{\mathrm{x}} \mathrm{Co}_{1-2 \mathrm{x}} \mathrm{Mn}_{\mathrm{x}}\right] \mathrm{O}_{2}$ cathode materials for lithium-ion batteries. Electrochem. Solid State Lett. 2001, 4, A200-A203. [CrossRef]

12. MacNeil, D.D.; Lu, Z.; Dahn, J.R. Structure and electrochemistry of $\mathrm{Li}\left[\mathrm{Ni}_{\mathrm{x}} \mathrm{Co}_{1-2 \mathrm{x}} \mathrm{Mn}_{\mathrm{x}}\right] \mathrm{O}_{2}(0 \leq \mathrm{x} \leq 1 / 2)$. J. Electrochem. Soc. 2002, 149, A1332-A1336. [CrossRef]

13. Zhang, S.; Ma, J.; Hu, Z.; Cui, G.; Chen, L. Identifying and addressing critical challenges of high-voltage layered ternary oxide cathode materials. Chem. Mater. 2019, 31, 6033-6065. [CrossRef]

14. Chen, Z.; Qin, Y.; Amine, K.; Sun, Y.-K. Role of surface coating on cathode materials for lithium-ion batteries. J. Mater. Chem. 2010, 20, 7606-7612. [CrossRef]

15. Myung, S.T.; Amine, K.; Sun, Y.-K. Surface modification of cathode materials from nano-to microscale for rechargeable lithium-ion batteries. J. Mater. Chem. 2010, 20, 7074-7095. [CrossRef]

16. Yoon, C.S.; Park, K.J.; Kim, U.H.; Kang, K.H.; Ryu, H.H.; Sun, Y.-K. High-energy Ni-rich Li[ $\left[\mathrm{Ni}_{\mathrm{x}} \mathrm{Co}_{\mathrm{y}} \mathrm{Mn}_{1-\mathrm{x}-\mathrm{y}}\right] \mathrm{O}_{2}$ cathodes via compositional partitioning for next-generation electric vehicles. Chem. Mater. 2017, 29, 10436-10445. [CrossRef]

17. Sun, H.H.; Ryu, H.-H.; Kim, U.-H.; Weeks, J.A.; Heller, A.; Sun, Y.-K.; Mullins, C.B. Beyond doping and coating: Prospective strategies for stable high-capacity layered Ni-rich cathodes. ACS Energy Lett. 2020, 5 , 1136-1146. [CrossRef]

18. Zubi, G.; Dufo-López, R.; Carvalho, M.; Pasaoglu, G. The lithium-ion battery: State of the art and future perspectives. Renew. Sustain. Energy Rev. 2018, 89, 292-308. [CrossRef]

19. Sun, Y.-K. High-capacity layered cathodes for next-generation electric vehicles. ACS Energy Lett. 2019, 4, 1042-1044. [CrossRef]

20. Kong, X.; Zhang, Y.; Peng, S.; Zeng, J.; Zhao, J. Superiority of single-crystal to polycrystalline $\mathrm{LiNi}_{\mathrm{x}} \mathrm{Co}_{\mathrm{y}} \mathrm{Mn}_{1-\mathrm{x}-\mathrm{y}} \mathrm{O}_{2}$ cathode materials in storage behaviors for lithium-ion batteries. ACS Sustain. Chem. Eng. 2020, 8, 14938-14948. [CrossRef]

21. Orman, H.J.; Wiseman, P.J. Cobalt (III) lithium oxide, $\mathrm{CoLiO}_{2}$ : Structure refinement by powder neutron diffraction. Acta Cryst. C 1984, 40, 12-14. [CrossRef]

22. Delmas, C.; Fouassier, C.; Hagenmuller, P. Structural classification and properties of the layered oxides. Phys. B 1980, 99, 81-85. [CrossRef]

23. Zhang, X.; Jiang, W.J.; Mauger, A.; Qi, L.; Gendron, F.; Julien, C.M. Minimization of the cation mixing in $\mathrm{Li}_{1+\mathrm{x}}(\mathrm{NCM})_{1-\mathrm{x}} \mathrm{Co}_{1 / 3} \mathrm{O}_{2}$ as cathode material. J. Power Sources 2010, 195, 1292-1301. [CrossRef]

24. Zhang, X.; Mauger, A.; Lu, Q.; Groult, H.; Perrigaud, L.; Gendron, F.; Julien, C.M. Synthesis and characterization of $\mathrm{LiNi}_{1 / 3} \mathrm{Mn}_{1 / 3} \mathrm{Co}_{1 / 3} \mathrm{O}_{2}$ by wet-chemical method. Electrochim. Acta. 2010, 55, 6440-6449. [CrossRef]

25. Nie, Y.; Xiao, W.; Miao, C.; Xu, M.; Wang, C. Effect of calcining oxygen pressure gradient on properties of $\mathrm{LiNi}_{0.8} \mathrm{Co}_{0.15} \mathrm{Al}_{0.05} \mathrm{O}_{2}$ cathode materials for lithium ion batteries. Electrochim. Acta 2020, 334, 135654. [CrossRef]

26. Aurbach, D.; Srur-Lavi, O.; Ghanty, C.; Dixit, M.; Haik, O.; Talianker, M.; Grinblat, Y.; Leifer, N.; Lavi, R.; Major, D.T.; et al. Studies of aluminum-doped $\mathrm{LiNi}_{0.5} \mathrm{Co}_{0.2} \mathrm{Mn}_{0.3} \mathrm{O}_{2}$ : Electrochemical behavior, aging, structural transformations, and thermal characteristics. J. Electrochem. Soc. 2015, 162, A1014-A1027. [CrossRef]

27. Kostecki, R.; McLarnon, F. Local-probe studies of degradation of composite $\mathrm{LiNi}_{0.80} \mathrm{Co}_{0.15} \mathrm{Al}_{0.05} \mathrm{O}_{2}$ cathodes in high-power lithium-ion cells. Electrochem. Solid State Lett. 2004, 7, A380-A383. [CrossRef]

28. Zhang, Y.; Wang, C.Y. Cycle-life characterization of automotive lithium-ion batteries with $\mathrm{LiNiO}_{2}$ cathode. J. Electrochem. Soc. 2009, 156, A527. [CrossRef] 
29. Tesla is Using State-of-the-Art Panasonic Batteries in the Model SP100D. The 100-kWh Battery Pack Contains 8256 Cells (18650-Type, Weight of $45 \mathrm{~g}$ ), which is a Total of $\sim 136$ Liters Leading to a Volumetric Energy Density of $732 \mathrm{Wh} \mathrm{L}^{-1}$. The Gravimetric Energy Density is $\sim 270 \mathrm{Wh} \mathrm{kg}^{-1}$. Available online: https://www.theverge.com/2019/4/11/18305976/tesla-panasonic-gigafactory-batteries-model-3 (accessed on 11 April 2019).

30. Biensan, P.; Simon, B.; Pérès, J.P.; de Guilbert, A.; Broussely, M.; Bodet, J.M.; Perton, F. On safety of lithium-ion cells. J. Power Sources 1999, 81, 906-912. [CrossRef]

31. Majumdar, S.B.; Nieto, S.; Katiyar, R.S. Synthesis and electrochemical properties of $\operatorname{LiNi}_{0.80}\left(\mathrm{Co}_{0.20-\mathrm{x}} \mathrm{Al}_{\mathrm{x}}\right) \mathrm{O}_{2}$ $(x=0.0$ and 0.05$)$ cathodes for Li ion rechargeable batteries. J. Power Sources 2006, 154, 262-267. [CrossRef]

32. Guilmard, M.; Pouillerie, C.; Croguennec, L.; Delmas, C. Structural and electrochemical properties of $\mathrm{LiNi}_{0.70} \mathrm{Co}_{0.15} \mathrm{Al}_{0.15} \mathrm{O}_{2}$. Solid State Ion. 2003, 160, 39-50. [CrossRef]

33. Xie, H.; Hu, G.; Du, K.; Peng, Z.; Cao, Y. An improved continuous co-precipitation method to synthesize $\mathrm{LiNi}_{0.80} \mathrm{Co}_{0.15} \mathrm{Al}_{0.05} \mathrm{O}_{2}$ cathode material. J. Alloys Compd. 2016, 666, 84-87. [CrossRef]

34. Zhang, L.; Zhao, Z.; Li, X.; Fang, H.; Wang, L.; Song, Y.; Jia, X. Synthesis and electrochemical performance of ropelike $\mathrm{LiNi}_{0.80} \mathrm{Co}_{0.15} \mathrm{Al}_{0.05} \mathrm{O}_{2}$ fiber with nano-building blocks. Mater. Res. Express 2020, 7, 015526. [CrossRef]

35. Liu, W.; Qin, M.; Gao, C.; Yu, D.; Yue, Y. Green and low-cost synthesis of $\mathrm{LiNi}_{0.80} \mathrm{Co}_{0.15} \mathrm{Al}_{0.05} \mathrm{O}_{2}$ cathode material for li-ion batteries. Mater. Lett. 2019, 246, 153-156. [CrossRef]

36. Wu, X.; Lu, J.; Han, Y.; Wu, H.; Bu, L.; Xie, J.; Qian, C.; Li, H.; Diao, G.; Chen, M.; et al. Template-assisted synthesis of $\mathrm{LiNi}_{0.80} \mathrm{Co}_{0.15} \mathrm{Al}_{0.05} \mathrm{O}_{2}$ hollow nanospheres as cathode material for lithium ion batteries. J. Mater. Sci. 2020, 55, 9493-9503. [CrossRef]

37. Purwanto, A.; Yudha, C.S.; Muhammas, K.I.; Algifari, B.G.; Widiyandari, H.; Sutopo, W. Synthesis of $\mathrm{LiNi}_{0.80} \mathrm{Co}_{0.15} \mathrm{Al}_{0.05} \mathrm{O}_{2}$ cathode material via flame-assisted spray pyrolysis method. Adv. Powder Technol. 2020, 31, 1674-1681. [CrossRef]

38. Gao, T.-P.; Wong, K.W.; Ng, K.M. High-quality $\mathrm{LiNi}_{0.80} \mathrm{Co}_{0.15} \mathrm{Al}_{0.05} \mathrm{O}_{2}$ cathode with excellent structural stability: Suppressed structural degradation and pore defects generation. Nano Energy 2020, 73, 104798. [CrossRef]

39. Bang, H.J.; Joachin, H.; Yang, H.; Amine, K.; Prakash, J. Contribution of the structural changes of $\mathrm{LiNi}_{0.80} \mathrm{Co}_{0.15} \mathrm{Al}_{0.05} \mathrm{O}_{2}$ cathodes on the exothermic reactions in li-ion cells. J. Electrochem. Soc. 2006, 153, A731-A737. [CrossRef]

40. Chebiam, R.V.; Prado, F.; Manthiram, A. Structural instability of delithiated $\mathrm{Li}_{1-\mathrm{x}} \mathrm{Ni}_{1-y} \mathrm{Co}_{\mathrm{y}} \mathrm{O}_{2}$ cathodes. J. Electrochem. Soc. 2001, 148, A49-A53. [CrossRef]

41. Hwang, S.; Chang, W.; Kim, S.M.; Su, D.; Kim, D.H.; Lee, J.Y.; Chung, K.Y.; Stach, E.A. Investigation of changes in the surface structure of $\mathrm{Li}_{\mathrm{x}} \mathrm{Ni}_{0.80} \mathrm{Co}_{0.15} \mathrm{Al}_{0.05} \mathrm{O}_{2}$ cathode materials induced by the initial charge. Chem. Mater. 2014, 26, 1084-1092. [CrossRef]

42. Betzin, C.; Wolfschmidt, H.; Luther, M. Long time behavior of $\mathrm{LiNi}_{0.80} \mathrm{Co}_{0.15} \mathrm{Al}_{0.05} \mathrm{O}_{2}$ based lithium-ion cells by small depth of discharge at specific state of charge for primary control reserve in a vitual energy storage plant. Energy Proc. 2016, 99, 235-242. [CrossRef]

43. Yan, P.; Zheng, J.; Zhang, J.G.; Wang, C. Atomic resolution structural and chemical imaging revealing the sequential migration of $\mathrm{Ni}, \mathrm{Co}$, and $\mathrm{Mn}$ upon the battery cycling of layered cathode. Nano Lett. 2017, 17, 3946-3951. [CrossRef]

44. Grenier, A.; Liu, H.; Wiaderek, K.M.; Lebens-Higgins, Z.W.; Borkiewicz, O.J.; Piper, L.F.J.; Chupas, P.J.; Chapman, K.W. Reaction heterogeneity in $\mathrm{LiNi}_{0.80} \mathrm{Co}_{0.15} \mathrm{Al}_{0.05} \mathrm{O}_{2}$ induced by surface layer. Chem. Mater. 2017, 29, 7345-7352. [CrossRef]

45. Khim, K.; Yiqing, H.; Sooyeon, H.; Andrew, D.G.; Stanly, M.W.; Guanwen, Z.; Eric, A.S. Tuning the activity of oxygen in $\mathrm{LiNi}_{0.80} \mathrm{Co}_{0.15} \mathrm{Al}_{0.05} \mathrm{O}_{2}$ battery electrodes. ACS Appl. Mater. Interfaces 2016, 8, 27762-27771.

46. Liu, H.; Liu, H.; Seymour, I.D.; Chernova, N.; Wiaderek, K.M.; Trease, N.M.; Chen, Y.; Ke, A.; Zhang, M.; Borkiewicz, O.J.; et al. Identifying the chemical and structural irreversibility in $\mathrm{LiNi}_{0.80} \mathrm{Co}_{0.15} \mathrm{Al}_{0.05} \mathrm{O}_{2}-\mathrm{a}$ model compound for classical layered intercalation. J. Mater. Chem. 2018, 6, 4189-4198. [CrossRef]

47. Zhang, H.; May, B.M.; Serrano-Sevillano, J.; Casas-Cabanas, M.; Cabana, J.; Wang, C.; Zhou, G. Facet-dependent rock-salt reconstruction on the surface of layered oxide cathodes. Chem. Mater. 2018, 30, 692-699. [CrossRef] 
48. Robert, R.; Novak, P. Switch of the charge storage mechanism of $\mathrm{Li}_{x} \mathrm{Ni}_{0.80} \mathrm{Co}_{0.15} \mathrm{Al}_{0.05} \mathrm{O}_{2}$ at overdischarge conditions. Chem. Mater. 2018, 30, 1907-1911. [CrossRef]

49. Kleiner, K.; Melke, J.; Merz, M.; Jakes, P.; Nagel, P.; Schuppler, S.; Liebau, V.; Ehrenberg, H. Unraveling the degradation process of $\mathrm{LiNi}_{0.80} \mathrm{Co}_{0.15} \mathrm{Al}_{0.05} \mathrm{O}_{2}$ electrodes in commercial lithium ion batteries by electronic structure investigations. ACS Appl. Mater. Interfaces 2015, 7, 19589-19600. [CrossRef]

50. Sallis, S.; Pereira, N.; Mukherjee, P.; Quackenbush, N.F.; Faenza, N.; Schlueter, C.; Lee, T.L.; Yang, W.L.; Cosandey, F.; Amatucci, G.G.; et al. Surface degradation of $\mathrm{Li}_{1-x} \mathrm{Ni}_{0.80} \mathrm{Co}_{0.15} \mathrm{Al}_{0.05} \mathrm{O}_{2}$ cathodes: Correlating charge transfer impedance with surface phase transformations. Appl. Phys. Lett. 2016, 108, 263902. [CrossRef]

51. Shikano, M.; Kobayashi, H.; Koike, S.; Sakaebe, H.; Ikenaga, E.; Kobayashi, K.; Tatsumi, K. Investigation of positive electrodes after cycle testing of high-power li-ion battery cells: II an approach to the power fading mechanism using hard X-ray photoemission spectroscopy. J. Power Sources 2007, 174, 795-799. [CrossRef]

52. Mori, D.; Kobayashi, H.; Shikano, M.; Nitani, H.; Kageyama, H.; Koike, S.; Sakaebe, H.; Tatsumi, K. Bulk and surface structure investigation for the positive electrodes of degraded lithium-ion cell after storage test using $\mathrm{X}$-ray absorption near-edge structure measurement. J. Power Sources 2009, 189, 676-680. [CrossRef]

53. Sasaki, T.; Nonaka, T.; Oka, H.; Okuda, C.; Itou, I.; Kondo, Y.; Takeuchi, Y.; Ukyo, Y.; Tatsumi, K.; Muto, S. Capacity-fading mechanisms of $\mathrm{LiNiO}_{2}$-based lithium-ion batteries $\mathrm{i}$ analysis by electrochemical and spectroscopic examination. J. Electrochem. Soc. 2009, 156, A289-A293. [CrossRef]

54. Miller, D.J.; Proff, C.; Wen, J.G.; Abraham, D.P.; Bareno, J. Observation of microstructural evolution in li battery cathode oxide particles by in situ electron microscopy. Adv. Energy Mater. 2013, 3, 1098-1103. [CrossRef]

55. Kleiner, K.; Dixon, D.; Jakes, P.; Melke, J.; Yavuz, M.; Roth, C.; Nikolowski, K.; Liebau, V.; Ehrenberg, H. Fatigue of $\mathrm{LiNi}_{0.80} \mathrm{Co}_{0.15} \mathrm{Al}_{0.05} \mathrm{O}_{2}$ in commercial Li-ion batteries. J. Power Sources 2015, 273, 70-82. [CrossRef]

56. Lang, M.; Darma, M.S.D.; Kleine, K.; Riekehr, L.; Mereacr, L.; Perez, M.A.; Liebau, V.; Ehrenberg, H. Post mortem analysis of fatigue mechanisms in $\mathrm{LiNi}_{0.80} \mathrm{Co}_{0.15} \mathrm{Al}_{0.05} \mathrm{O}_{2}-\mathrm{LiNi}_{0.5} \mathrm{Co}_{0.2} \mathrm{Mn}_{0.3} \mathrm{O}_{2}-\mathrm{LiMn}_{2} \mathrm{O}_{4} /$ graphite lithium ion batteries. J. Power Sources 2016, 326, 397-409. [CrossRef]

57. Wandt, J.; Freiberg, A.T.S.; Ogrodnik, A.; Gasteiger, H.A. Singlet oxygen evolution from layered transition metal oxide cathode materials and its implications for lithium-ion batteries. Mater. Today 2018, 21, 825-833. [CrossRef]

58. Strehle, B.; Kleiner, K.; Jung, R.; Chesneau, F.; Mendez, M.; Gasteiger, H.A.; Piana, M. The role of oxygen release from $\mathrm{Li}$ - and $\mathrm{Mn}$-rich layered oxides during the first cycles investigated by on-line electrochemical mass spectrometry. J. Electrochem. Soc. 2017, 164, A400-A406. [CrossRef]

59. Renfrew, S.E.; McCloskey, B.D. Residual lithium carbonate predominantly accounts for first cycle $\mathrm{CO}_{2}$ and CO outgassing of li-stoichiometric and li-rich layered transition-metal oxides. J. Am. Chem. Soc. 2017, 137, 17853-17860. [CrossRef]

60. Lin, F.; Markus, I.M.; Nordlund, D.; Weng, T.C.; Asta, H.L.; Xin, M.D.; Doeff, M.M. Surface reconstruction and chemical evolution of stoichiometric layered cathode materials for lithium-ion batteries. Nat. Commun. 2014, 5, 3529. [CrossRef]

61. Lebens-Higgins, Z.W.; Sallis, S.; Faenza, N.V.; Badway, F.; Pereira, N.; Halat, D.M.; Wahila, M.; Schlueter, C.; Lee, T.L.; Yang, W.; et al. Evolution of the electrode-electrolyte interface of $\mathrm{LiNi}_{0.80} \mathrm{Co}_{0.15} \mathrm{Al}_{0.05} \mathrm{O}_{2}$ electrodes due to electrochemical and thermal stress. Chem. Mater. 2018, 30, 958-969. [CrossRef]

62. Faenza, N.V.; Lebens-Higgins, Z.W.; Mukherjee, P.; Sallis, S.; Pereira, N.; Badway, F.; Halajko, A.; Ceder, G.; Cosandey, F.; Piper, L.F.J.; et al. Electrolyte-induced surface transformation and transition-metal dissolution of fully delithiated $\mathrm{LiNi}_{0.80} \mathrm{Co}_{0.15} \mathrm{Al}_{0.05} \mathrm{O}_{2}$. Langmuir 2017, 33, 9333-9353. [CrossRef]

63. Abraham, D.P.; Roth, E.P.; Kostecki, R.; McCarthy, K.; MacLaren, S.; Doughty, D.H. Diagnostic examination of thermally abused high-power lithium-ion cells. J. Power Sources 2006, 161, 648-657. [CrossRef]

64. Mauger, A.; Julien, C.M. Critical review on lithium-ion batteries: Are they safe? Sustainable? Ionics 2017, 23, 1933-1947. [CrossRef]

65. Nam, G.W.; Park, N.-Y.; Park, K.-J.; Yang, J.; Liu, J.; Yoon, C.S.; Sun, Y.-K. Capacity fading of Ni-rich NCA cathodes: Effect of microcracking extent. ACS Energy Lett. 2019, 4, 2995-3001. [CrossRef]

66. Ryu, H.H.; Park, K.J.; Yoon, C.S.; Sun, Y.-K. Capacity fading of Ni-rich $\mathrm{Li}\left[\mathrm{Ni}_{\mathrm{x}} \mathrm{Co}_{\mathrm{y}} \mathrm{Mn}_{1-\mathrm{x}-\mathrm{y}}\right] \mathrm{O}_{2}(0.6 \leq \mathrm{x} \leq 0.95)$ cathodes for high-energy-density lithium-ion batteries: Bulk or surface degradation? Chem. Mater. 2018, 30, 1155-1163. [CrossRef]

67. Ryu, H.H.; Park, G.T.; Yoon, C.S.; Sun, Y.-K. Microstructural degradation of Ni-rich Li $\left[\mathrm{Ni}_{x} \mathrm{Co}_{y} \mathrm{Mn}_{1-\mathrm{x}-\mathrm{y}}\right] \mathrm{O}_{2}$ cathodes during accelerated calendar aging. Small 2018, 14, 1803179. [CrossRef] 
68. Pender, J.P.; Jha, G.; Youn, D.H.; Ziegler, J.M.; Andoni, I.; Choi, E.J.; Heller, A.; Dunn, B.S.; Weiss, P.S.; Penner, R.M.; et al. Electrode degradation in metal-mon batteries. ACS Nano 2020, 14, 1243. [CrossRef]

69. Belharouak, I.; Lu, W.; Vissers, D.; Amine, K. Safety characteristics of $\mathrm{Li}\left(\mathrm{Ni}_{0.8} \mathrm{Co}_{0.15} \mathrm{Al}_{0.05}\right) \mathrm{O}_{2}$ and $\mathrm{Li}\left(\mathrm{Ni}_{1 / 3} \mathrm{Co}_{1 / 3} \mathrm{Mn}_{1 / 3}\right) \mathrm{O}_{2}$. Electrochem. Commun. 2006, 8, 329-335. [CrossRef]

70. Leifer, N.; Srur-Lavi, O.; Matlahov, I.; Markovsky, B.; Aurbach, D.; Goobes, G. $\operatorname{LiNi}_{0.8} \mathrm{Co}_{0.15} \mathrm{Al}_{0.05} \mathrm{O}_{2}$ cathode material: New insights via ${ }^{7} \mathrm{Li}$ and ${ }^{27} \mathrm{Al}$ magic-angle spinning NMR spectroscopy. Chem. Mater. 2016, 28, 7594-7604. [CrossRef]

71. He, P.; Yu, H.; Li, D.; Zhou, H. Layered lithium transition metal oxide cathodes towards high energy lithium-ion batteries. J. Mater. Chem. 2012, 22, 3680-3695. [CrossRef]

72. Guilmard, M.; Croguennec, L.; Delmas, C. Thermal stability of lithium nickel oxide derivatives. Part II: $\mathrm{Li}_{\mathrm{x}} \mathrm{Ni}_{0.70} \mathrm{Co}_{0.15} \mathrm{Al}_{0.15} \mathrm{O}_{2}$ and $\mathrm{Li}_{\mathrm{x}} \mathrm{Ni}_{0.90} \mathrm{Mn}_{0.10} \mathrm{O}_{2}(\mathrm{x}=0.50$ and 0.30$)$. Comparison with $\mathrm{Li}_{\mathrm{x}} \mathrm{Ni}_{1.02} \mathrm{O}_{2}$ and $\mathrm{Li}_{\mathrm{x}} \mathrm{Ni}_{0.89} \mathrm{Al}_{0.16} \mathrm{O}_{2}$. Chem. Mater. 2003, 15, 4484-4493. [CrossRef]

73. Whittingham, M.S. Ultimate limits to intercalation reactions for lithium batteries. Chem. Rev. 2014, 114, 11414-11443. [CrossRef]

74. Zhang, H.; Karki, K.; Huang, Y.; Whittingham, M.S.; Stach, E.A.; Zhou, G. Atomic insight into the layered/spinel phase transformation in charged $\mathrm{LiNi}_{0.80} \mathrm{Co}_{0.15} \mathrm{Al}_{0.05} \mathrm{O}_{2}$ cathode particles. J. Phys. Chem. C 2017, 121, 1421-1430. [CrossRef]

75. Guilmard, M.; Croguennec, L.; Denux, D.; Delmas, C. Thermal stability of lithium nickel oxide derivatives. Part I: $\mathrm{Li}_{\mathrm{x}} \mathrm{Ni}_{1.02} \mathrm{O}_{2}$ and $\mathrm{Li}_{\mathrm{x}} \mathrm{Ni}_{0.89} \mathrm{Al}_{0.16} \mathrm{O}_{2}$ ( $\mathrm{x}=0.50$ and 0.30). Chem. Mater. 2003, 15, 4476-4483. [CrossRef]

76. Kim, S.; Ma, X.; Ong, S.P.; Ceder, G. A comparison of destabilization mechanisms of the layered $\mathrm{Na}_{\mathrm{x}} \mathrm{Mo}_{2}$ and $\mathrm{Li}_{x} \mathrm{Mo}_{2}$ compounds upon alkali de-intercalation. Phys. Chem. Chem. Phys. 2012, 14, 15571-15578. [CrossRef]

77. Li, H.; Zhang, L.; Qian, K.; Shi, R.; Kang, F.; Li, B. Combination effect of bulk structure change and surface rearrangement on the electrochemical kinetics of $\mathrm{LiNi}_{0.80} \mathrm{Co}_{0.15} \mathrm{Al}_{0.05} \mathrm{O}_{2}$ during initial charging processes. ACS Appl. Mater. Interfaces 2018, 10, 41370-41379. [CrossRef]

78. Wolfram, M.; Yu, Y.-S.; May, B.M.; Lebens-Higgings, Z.W.; Sallis, S.; Faenza, N.V.; Pereira, N.; Shirato, N.; Rose, V.; Shapiro, D.A.; et al. Mapping competitive reduction upon charging in $\mathrm{LiNi}_{0.8} \mathrm{Co}_{0.15} \mathrm{Al}_{0.05} \mathrm{O}_{2}$ primary particles. Chem. Mater. 2020, 32, 6161-6175.

79. Kim, J.; Ma, H.; Cha, H.; Lee, H.; Sung, J.; Seo, M.; Oh, P.; Park, M.; Cho, J. A highly stabilized nickel-rich cathode material by nanoscale epitaxy control for high-energy lithium-ion batteries. Energy Environ. Sci. 2018, 11, 1449-1459. [CrossRef]

80. Julien, C.M.; Mauger, A.; Groult, H.; Zaghib, K. Surface modification of positive electrode materials for lithium-ion batteries. Thin Solid Films 2014, 572, 200-207. [CrossRef]

81. Ju, J.H.; Chung, Y.M.; Bak, Y.R.; Hwang, M.J.; Ryu, K.S. The effects of carbon nano-coating on $\mathrm{Li}\left(\mathrm{Ni}_{0.80} \mathrm{Co}_{0.15} \mathrm{Al}_{0.05}\right) \mathrm{O}_{2}$ cathode material using organic carbon for Li-ion battery. Surf. Rev. Lett. 2010, 17, 51-58. [CrossRef]

82. Binder, J.O.; Culver, S.P.; Pinedo, R.; Weber, D.A.; Friedrich, M.S.; Gries, K.I.; Volz, K.; Zeier, W.G.; Janek, J. Investigation of fluorine and nitrogen as anionic dopants in nickel-rich cathode materials for lithium-ion batteries. ACS Appl. Mater. Interfaces 2018, 10, 44452-44462. [CrossRef]

83. Zhu, L.; Liu, Y.; Wu, W.; Wu, X.; Tang, W.; Wu, Y. Surface fluorinated $\mathrm{LiNi}_{0.8} \mathrm{Co}_{0.15} \mathrm{Al}_{0.05} \mathrm{O}_{2}$ as a positive electrode material for lithium ion batteries. J. Mater. Chem. A 2015, 3, 15156-15162. [CrossRef]

84. Zhao, B.; Si, J.; Cao, C.; Zhang, J.; Xia, B.; Xie, J.; Li, B.; Jiang, Y. Enhanced electrochemical performance of $\mathrm{LiNi}_{0.80} \mathrm{Co}_{0.15} \mathrm{Al}_{0.05} \mathrm{O}_{2}$ cathode by reducing lithium residue with low-temperature fluorination treatment. Solid Stat. Ion. 2019, 339, 114998. [CrossRef]

85. Liu, W.; Tang, X.; Qin, M.; Li, G.; Deng, J.; Huang, X. FeF 3 -coated $\mathrm{LiNi}_{0.80} \mathrm{Co}_{0.15} \mathrm{Al}_{0.05} \mathrm{O}_{2}$ cathode materials with improved electrochemical properties. Mater. Lett. 2016, 185, 96-99. [CrossRef]

86. Qiu, Z.; Liu, Z.; Fu, X.; Liu, J.; Zeng, Q. Improving the cycling performance of $\mathrm{LiNi}_{0.8} \mathrm{Co}_{0.15} \mathrm{Al}_{0.05} \mathrm{O}_{2}$ cathode materials via zirconium and fluorine co-substitution. J. Alloys Compd. 2019, 806, 136-145. [CrossRef]

87. Jin, S.-J.; Seo, J.-S.; Na, B.-K. Effect of $\mathrm{MgF}_{2}$ surface modification for $\mathrm{LiNi}_{0.80} \mathrm{Co}_{0.15} \mathrm{Al}_{0.05} \mathrm{O}_{2}$ cathode material on improving electrochemical characteristics. Korean Chem. Eng. Res. 2020, 58, 52-58.

88. Cho, Y.; Lee, Y.S.; Park, S.A.; Lee, Y.; Cho, J. $\mathrm{LiNi}_{0.80} \mathrm{Co}_{0.15} \mathrm{Al}_{0.05} \mathrm{O}_{2}$ cathodes materials prepared by $\mathrm{TiO}_{2}$ nanoparticle coatings on $\mathrm{Ni}_{0.80} \mathrm{Co}_{0.15} \mathrm{Al}_{0.05}(\mathrm{OH})_{2}$ precursors. Electrochim. Acta 2010, 56, 333-339. [CrossRef]

89. Zhou, P.; Zhang, Z.; Meng, H.; Lu, Y.; Cao, J.; Cheng, F.; Tao, Z.; Chen, J. SiO cathode material for rechargeable li-ion batteries. Nanoscale 2016, 8, 19263-19269. [CrossRef] 
90. Zhang, Z.; Zhou, P.; Meng, H.; Chen, C.; Cheng, F.; Tao, Z.; Chen, J. Amorphous $\mathrm{Zr}(\mathrm{OH})_{4}$ coated $\mathrm{LiNi}_{0.915} \mathrm{Co}_{0.075} \mathrm{Al}_{0.01} \mathrm{O}_{2}$ cathode material with enhanced electrochemical performance for lithium ion batteries. J. Energy Chem. 2017, 26, 481-487. [CrossRef]

91. Roh, K.; Yang, S.; Hong, B.; Roh, Y. Structural and electrical properties of yttrium oxide with tungsten gate. J. Korean Phys. Soc. 2002, 40, 103-106.

92. Kim, J.-Y.; Sangjin, K.; Kim, D.H. Electronic structural studies on the improved thermal stability of $\mathrm{LiNi}_{0.8} \mathrm{Co}_{0.15} \mathrm{Al}_{0.05} \mathrm{O}_{2}$ by $\mathrm{ZrO}_{2}$ coating for lithium ion batteries. J. Appl. Electrochem. 2017, 47, 565-572. [CrossRef]

93. Liu, B.-S.; Sui, X.-L.; Zhang, S.-H.; Yu, F.-D.; Xue, Y.; Zhang, Y.; Zhou, Y.-X.; Wang, Z.-B. Investigation on electrochemical performance of $\mathrm{LiNi}_{0.8} \mathrm{Co}_{0.15} \mathrm{Al}_{0.05} \mathrm{O}_{2}$ coated by heterogeneous layer of $\mathrm{TiO}_{2}$. J. Alloys Compd. 2018, 739, 961-971. [CrossRef]

94. Du, K.; Xie, H.B.; Hu, G.R.; Peng, Z.D.; Cao, Y.B.; Yu, F. Enhancing the thermal and upper voltage performance of ni-rich cathode material by a homogeneous and facile coating method: Spray-drying coating with nano- $\mathrm{Al}_{2} \mathrm{O}_{3}$. ACS Appl. Mater. Interfaces 2016, 8, 17713-17720. [CrossRef]

95. Loghavi, M.M.; Mohammadi-Manes, H.; Eqra, R. $\mathrm{Y}_{2} \mathrm{O}_{3}$-decorated $\mathrm{LiNi}_{0.8} \mathrm{Co}_{0.15} \mathrm{Al}_{0.05} \mathrm{O}_{2}$ cathode material with improved electrochemical performance for lithium-ion batteries. J. Electroanal. Chem. 2019, 848, 113326. [CrossRef]

96. Huang, Y.; Huang, Y.; Hu, X. Enhanced electrochemical performance of $\mathrm{LiNi}_{0.8} \mathrm{Co}_{0.15} \mathrm{Al}_{0.05} \mathrm{O}_{2}$ by nanoscale surface modification with $\mathrm{Co}_{3} \mathrm{O}_{4}$. Electrochim. Acta 2017, 231, 294-299. [CrossRef]

97. Mohanty, D.; Dahlberg, K.; King, D.M.; David, L.A.; Sefat, A.S.; Wood, D.L.; Daniel, C.; Dhar, S.; Mahajan, V.; Lee, M.; et al. Modification of Ni-rich FCG NCM and NCA cathodes by atomic layer deposition: Preventing surface phase transitions for high-voltage lithium-ion batteries. Sci. Rep. 2016, 6, 26532. [CrossRef]

98. Lai, Y.-Q.; Xu, M.; Zhang, Z.-A.; Gao, C.-H.; Wang, P.; Yu, Z.-Y. Optimized structure stability and electrochemical performance of $\mathrm{LiNi}_{0.8} \mathrm{Co}_{0.15} \mathrm{Al}_{0.05} \mathrm{O}_{2}$ by sputtering nanoscale $\mathrm{ZnO}$ film. J. Power Sources 2016, 309, 20-26. [CrossRef]

99. He, X.; Du, C.; Shen, B.; Chen, C.; Xu, X.; Wang, Y.; Zuo, P.; Ma, Y.; Cheng, X.; Yin, G. Electronically conductive Sb-doped $\mathrm{SnO}_{2}$ nanoparticles coated $\mathrm{LiNi}_{0.8} \mathrm{Co}_{0.15} \mathrm{Al}_{0.05} \mathrm{O}_{2}$ cathode material with enhanced electrochemical properties for Li-ion batteries. Electrochim. Acta 2017, 236, 273-279. [CrossRef]

100. Lee, D.J.; Scrosati, B.; Sun, Y.K. Ni $\mathrm{Ni}_{3}\left(\mathrm{PO}_{4}\right)_{2}$-coated $\mathrm{Li}\left(\mathrm{Ni}_{0.80} \mathrm{Co}_{0.15} \mathrm{Al}_{0.05}\right) \mathrm{O}_{2}$ lithium battery electrode with improved cycling performance at $55^{\circ} \mathrm{C}$. J. Power Sources 2011, 196, 7742-7746. [CrossRef]

101. Jo, C.-H.; Cho, D.-H.; Noh, H.-J.; Yashiro, H.; Sun, Y.-K.; Myung, S.T. An effective method to reduce residual lithium compounds on $\mathrm{Ni}$-rich $\mathrm{Li}\left[\mathrm{Ni}_{0.6} \mathrm{Co}_{0.2} \mathrm{Mn}_{0.2}\right] \mathrm{O}_{2}$ active material using a phosphoric acid derived $\mathrm{Li}_{3} \mathrm{PO}_{4}$ nanolayer. Nano Res. 2014, 8, 1464-1479. [CrossRef]

102. Sun, K.; Dillon, S.J. A mechanism for the improved rate capability of cathodes by lithium phosphate surficial films. Electrochem. Commun. 2011, 13, 200-202. [CrossRef]

103. Lee, Y.; Lee, J.; Lee, K.Y.; Mun, J.; Lee, J.K.; Choi, W. Facile formation of a $\mathrm{Li}_{3} \mathrm{PO}_{4}$ coating layer during the synthesis of a lithium-rich layered oxide for high-capacity lithium-ion batteries. J. Power Sources 2016, 315, 284-293. [CrossRef]

104. Tang, Z.-F.; Wu, R.; Huang, P.-F.; Wang, Q.-S.; Chen, C.-H. Improving the electrochemical performance of $\mathrm{Ni}$-rich cathode material $\mathrm{LiNi}_{0.815} \mathrm{Co}_{0.15} \mathrm{Al}_{0.035} \mathrm{O}_{2}$ by removing the lithium residues and forming $\mathrm{Li}_{3} \mathrm{PO}_{4}$ coating layer. J. Alloys Compd. 2017, 693, 1157-1163. [CrossRef]

105. Duan, J.; Wu, C.; Cao, Y.; Du, K.; Peng, Z.; Hu, G. Enhanced electrochemical performance and thermal stability of $\mathrm{LiNi}_{0.80} \mathrm{Co}_{0.15} \mathrm{Al}_{0.05} \mathrm{O}_{2}$ via nano-sized $\mathrm{LiMnPO}_{4}$ coating. Electrochim. Acta 2016, 221, 14-22. [CrossRef]

106. Zhao, S.; Shao, L.; Li, X.; Yang, L.; Wei, B.; Yang, Y.; Zhao, H.; Yin, D.; Ma, W.; Wang, Z. Acid-corrosion-formed amorphous phosphate surfaces improve electrochemical stability of $\mathrm{LiNi}_{0.80} \mathrm{Co}_{0.15} \mathrm{Al}_{0.05} \mathrm{O}_{2}$ cathodes. Corrosion Sci. 2020, 168, 108553. [CrossRef]

107. Huang, B.; Li, X.; Wang, Z.; Guo, H. A facile process for coating amorphous $\mathrm{FePO}_{4}$ onto $\mathrm{LiNi}_{0.80} \mathrm{Co}_{0.15} \mathrm{Al}_{0.05} \mathrm{O}_{2}$ and the effects on its electrochemical properties. Mater. Lett. 2014, 131, 210-213. [CrossRef]

108. Xia, S.; Li, F.; Chen, F.; Guo, H. Preparation of $\mathrm{FePO}_{4}$ by liquid-phase method and modification on the surface of $\mathrm{LiNi}_{0.80} \mathrm{Co}_{0.15} \mathrm{Al}_{0.05} \mathrm{O}_{2}$ cathode material. J. Alloys Compd. 2018, 731, 428-436. [CrossRef]

109. Chen, J.; Zhu, L.; Jia, D.; Jiang, X.; Wu, Y.; Hao, Q.; Xia, X.; Ouyang, Y.; Peng, L.; Tang, W.; et al. $\mathrm{LiNi}_{0.80} \mathrm{Co}_{0.15} \mathrm{Al}_{0.05} \mathrm{O}_{2}$ cathodes exhibiting improved capacity retention and thermal stability due to a lithium iron phosphate coating. Electrochim. Acta 2019, 312, 179-187. [CrossRef] 
110. Huang, W.-J.; Zheng, J.-Y.; Liu, J.J.; Yang, R.-M.; Cheng, F.-X.; Suo, H.-B.; Guo, H.; Xia, S.-B. Boosting rate performance of $\mathrm{LiNi}_{0.80} \mathrm{Co}_{0.15} \mathrm{Al}_{0.05} \mathrm{O}_{2}$ cathode by simply mixing lithium iron phosphate. J. Alloys Compd. 2020, 827, 154296. [CrossRef]

111. Wei, Y.; Zhou, C.; Zhao, D.; Wang, G. Enhanced electrochemical performance and safety of $\mathrm{LiNi}_{0.80} \mathrm{Co}_{0.15} \mathrm{Al}_{0.05} \mathrm{O}_{2}$ by $\mathrm{LiFePO}_{4}$ modification. Chem. Phys. Lett. 2020, 751, 137480. [CrossRef]

112. Wu, G.; Zhou, Y. TiP $\mathrm{O}_{7}$-coated $\mathrm{LiNi}_{0.80} \mathrm{Co}_{0.15} \mathrm{Al}_{0.05} \mathrm{O}_{2}$ cathode materials with improved thermal stability and superior cycle life. J. Energy Chem. 2019, 28, 151-159. [CrossRef]

113. Lim, S.N.; Ahn, W.; Yeon, S.H.; Park, S.B. Enhanced elevated-temperature performance of $\mathrm{LiNi}_{0.80} \mathrm{Co}_{0.15} \mathrm{Al}_{0.05} \mathrm{O}_{2}$ electrodes coated with $\mathrm{Li}_{2} \mathrm{O}-2 \mathrm{~B}_{2} \mathrm{O}_{3}$ glass. Electrochim. Acta 2014, 136, 1-9. [CrossRef]

114. Yang, Z.; Li, Z.; Huang, Y.; Zhang, M.; Liu, C.; Zhang, D.; Cao, G. Artificial interface stabilized $\mathrm{LiNi}_{0.80} \mathrm{Co}_{0.15} \mathrm{Al}_{0.05} \mathrm{O}_{2} @$ Polysiloxane cathode for stable cycling lithium-ion batteries. J. Power Sources 2020, 471, 228480. [CrossRef]

115. Srur-Lavi, O.; Miikkulainen, V.; Markovsky, B.; Grinblat, J.; Talianker, M.; Fleger, Y.; Cohen-Taguri, G.; Mor, A.; Tal-Yosef, Y.; Aurbach, D. Studies of the electrochemical behavior of $\mathrm{LiNi}_{0.80} \mathrm{Co}_{0.15} \mathrm{Al}_{0.05} \mathrm{O}_{2}$ electrodes coated with $\mathrm{LiAlO}_{2}$. J. Electrochem. Soc. 2017, 164, A3266-A3275. [CrossRef]

116. Robert, R.; Bünzli, C.; Berg, E.J.; Novak, P. Activation mechanism of $\mathrm{LiNi}_{0.80} \mathrm{Co}_{0.15} \mathrm{Al}_{0.05} \mathrm{O}_{2}$ : Surface and bulk operando electrochemical, differential electrochemical mass spectrometry, and X-ray diffraction analyses. Chem. Mater. 2015, 27, 526-536. [CrossRef]

117. Rougier, A.; Saadoune, I.; Gravereau, P.; Willmann, P.; Delmas, C. Effect of cobalt substitution on cationic distribution in $\mathrm{LiNi}_{1-y} \mathrm{Co}_{y} \mathrm{O}_{2}$ electrode materials. Solid State Ion. 1996, 90, 83-90. [CrossRef]

118. Song, C.; Wang, W.; Peng, H.; Wang, Y.; Zhao, C.; Zhang, H.; Tang, Q.; Lv, J.; Du, X.; Dou, Y. Improving the electrochemical performance of $\mathrm{LiNi}_{0.80} \mathrm{Co}_{0.15} \mathrm{Al}_{0.05} \mathrm{O}_{2}$ in lithium-ion batteries by $\mathrm{LiAlO}_{2}$ surface modification. Appl. Sci. 2018, 8, 378. [CrossRef]

119. Kwak, H.W.; Park, Y.J. $\mathrm{Li}_{2} \mathrm{MoO}_{4}$ coated Ni-rich cathode for all-solid-state batteries. Thin Solid Films 2018, 660, 625-630. [CrossRef]

120. He, X.; Xu, X.; Wang, L.; Du, C.; Cheng, X.; Zuo, P.; Ma, Y.; Yin, G. Enhanced electrochemical performance of $\mathrm{LiNi}_{0.80} \mathrm{Co}_{0.15} \mathrm{Al}_{0.05} \mathrm{O}_{2}$ cathode Material via $\mathrm{Li}_{2} \mathrm{TiO}_{3}$ nanoparticles coating. J. Electrochem. Soc. 2019, 166, A143-A150. [CrossRef]

121. Xiong, F.; Chen, Z.; Huang, C.; Wang, T.; Zhang, W.; Yang, Z.; Chen, F. Near-equilibrium control of $\mathrm{Li}_{2} \mathrm{TiO}_{3}$ nanoscale layer coated on $\mathrm{LiNi}_{0.80} \mathrm{Co}_{0.15} \mathrm{Al}_{0.05} \mathrm{O}_{2}$ cathode materials for enhanced electrochemical performance. Inorg. Chem. 2019, 58, 15498-15506. [CrossRef]

122. Liu, P.; Xiao, L.; Chen, Y.; Chen, H. Highly enhanced electrochemical performances of $\mathrm{LiNi}_{0.815} \mathrm{Co}_{0.15} \mathrm{Al}_{0.035} \mathrm{O}_{2}$ by coating via conductively $\mathrm{LiTiO}_{2}$ for lithium-ion batteries. Ceramics Int. 2019, 45, 18398-18405. [CrossRef]

123. He, X.; Han, G.; Lou, S.; Du, L.; Xu, X.; Du, C.; Cheng, X.; Zuo, P.; Ma, Y.; Huo, H. Improved electrochemical performance of $\mathrm{LiNi}_{0.80} \mathrm{Co}_{0.15} \mathrm{Al}_{0.05} \mathrm{O}_{2}$ cathode material by coating of graphene nanodots. J. Electrochem. Soc. 2019, 166, A1038-A1044. [CrossRef]

124. Luo, W.; Liu, L.; Yu, J.; Fang, C. Templated assembly of $\mathrm{LiNi}_{0.80} \mathrm{Co}_{0.15} \mathrm{Al}_{0.05} \mathrm{O}_{2}$ /graphene nano composite with high rate capability and long-term cyclability for lithium ion battery. J. Alloys Compd. 2019, 810, 151786. [CrossRef]

125. He, X.; Feng, Z.; Zhou, L.; Xu, X. A synchronously dual-conductive coating towards enhancing the electrochemical performance of $\mathrm{LiNi}_{0.80} \mathrm{Co}_{0.15} \mathrm{Al}_{0.05} \mathrm{O}_{2}$ cathode material. J. Alloys Compd. 2021, 852, 156966. [CrossRef]

126. Xia, S.B.; Zhang, Y.J.; Dong, P.; Zhang, Y.N. Synthesis cathode material $\mathrm{LiNi}_{0.80} \mathrm{Co}_{0.15} \mathrm{Al}_{0.05} \mathrm{O}_{2}$ with two step solid-state method under air stream. Eur. Phys. J. Appl. Phys. 2014, 65, 10401. [CrossRef]

127. Wu, N.T.; Wu, H.; Liu, S.J.; Liao, J.Y.; Zhang, Y. Facile synthesis of one-dimensional $\mathrm{LiNi}_{0.80} \mathrm{Co}_{0.15} \mathrm{Al}_{0.05} \mathrm{O}_{2}$ microrods as advanced cathode materials for lithium ion batteries. J. Mater. Chem. A 2015, 3, 13648-13652. [CrossRef]

128. Xie, H.B.; Du, K.; Hu, G.R.; Duan, J.G.; Peng, Z.D.; Zhang, Z.J.; Cao, Y.B. Synthesis of $\operatorname{LiNi}_{0.80} \mathrm{Co}_{0.15} \mathrm{Al}_{0.15} \mathrm{O}_{2}$ with 5-sulfosalicylic acid as a chelating agent and its electrochemical properties. J. Mater. Chem. A 2015, 3, 20236-20243. [CrossRef]

129. Makimura, Y.; Sasaki, T.; Nonaka, T.; Nishimura, Y.F.; Uyama, T.; Okuda, C.; Itou, Y.; Takeuchi, Y. Factors affecting cycling life of $\mathrm{LiNi}_{0.80} \mathrm{Co}_{0.15} \mathrm{Al}_{0.05} \mathrm{O}_{2}$ for lithium-ion batteries. J. Mater. Chem. A 2016, 4, 8350-8358. [CrossRef] 
130. Qiu, Z.; Zhang, Y.; Dong, P.; Xia, S.; Yao, Y. A facile method for synthesis $\mathrm{LiNi}_{0.80} \mathrm{Co}_{0.15} \mathrm{Al}_{0.15} \mathrm{O}_{2}$ cathode material. Solid State Ion. 2017, 307, 73-78. [CrossRef]

131. Nie, Y.; Xiao, W.; Miao, C.; Fang, R.; Kou, Z.; Wang, D.; Xu, M.; Wang, C. Boosting the electrochemical performance of $\mathrm{LiNi}_{0.80} \mathrm{Co}_{0.15} \mathrm{Al}_{0.05} \mathrm{O}_{2}$ cathode materials in-situ modified with $\mathrm{Li}_{1.3} \mathrm{Al}_{0.3} \mathrm{Ti}_{1.7}\left(\mathrm{PO}_{4}\right)_{3}$ fast ion conductor for lithium-ion batteries. Electrochim. Acta 2020, 353, 136477. [CrossRef]

132. Ju, J.H.; Ryu, K.S. Synthesis and electrochemical performance of $\mathrm{Li}\left(\mathrm{Ni}_{0.80} \mathrm{Co}_{0.15} \mathrm{Al}_{0.05}\right)_{0.8}\left(\mathrm{Ni}_{0.5} \mathrm{Mn}_{0.5}\right)_{0.2} \mathrm{O}_{2}$ with core-shell structure as cathode material for Li-ion batteries. J. Alloys Compd. 2011, 509, 7985-7992. [CrossRef]

133. Cho, S.-W.; Kim, G.-O.; Ju, J.-H.; Oh, J.-W.; Ryu, K.-S. X-ray absorption spectroscopy studies of the Ni ion of $\mathrm{Li}\left(\mathrm{Ni}_{0.80} \mathrm{Co}_{0.15} \mathrm{Al}_{0.05}\right)_{0.8}\left(\mathrm{Ni}_{0.5} \mathrm{Mn}_{0.5}\right)_{0.2} \mathrm{O}_{2}$ with a core-shell structure and $\mathrm{LiNi}_{0.80} \mathrm{Co}_{0.15} \mathrm{Al}_{0.05} \mathrm{O}_{2}$ as cathode materials. Mater. Res. Bull. 2012, 47, 2830-2833. [CrossRef]

134. Zhao, J.; Wang, Z.; Wang, J.; Guo, H.; Li, X.; Gui, W.; Chen, N.; Yan, G. Anchoring $\mathrm{K}^{+}$in $\mathrm{Li}^{+}$sites of $\mathrm{LiNi}_{0.80} \mathrm{Co}_{0.15} \mathrm{Al}_{0.05} \mathrm{O}_{2}$ cathode material to suppress its structural degradation during high-voltage cycling. Energy Technol. 2018, 6, 2358-2366. [CrossRef]

135. Chen, H.; Hu, Q.Y.; Huang, Z.M.; He, Z.J.; Wang, Z.X.; Guo, H.J.; Li, X.H. Synthesis and electrochemical study of $\mathrm{Zr}$-doped $\mathrm{LiLi}_{0.2} \mathrm{Mn}_{0.54} \mathrm{Ni}_{0.13} \mathrm{Co}_{0.13} \mathrm{O}_{2}$ as cathode material for Li-ion battery. Ceram. Int. 2016, 42, 263-269. [CrossRef]

136. Singh, G.; Thomas, R.; Kumar, A.; Katiyar, R.S. Electrochemical behavior of Cr-doped composite $\mathrm{Li}_{2} \mathrm{MnO}_{3}-\mathrm{LiMn}_{0.5} \mathrm{Ni}_{0.5} \mathrm{O}_{2}$ cathode materials. J. Electrochem. Soc. 2012, 159, A410-A420. [CrossRef]

137. Xi, Z.; Wang, Z.; Peng, W.; Guo, H.; Wang, J. Effect of copper and iron substitution on the structures and electrochemical properties of $\mathrm{LiNi}_{0.8} \mathrm{Co}_{0.2} \mathrm{O}_{2}$ cathode materials. Energy Sci. Eng. 2020, 8, 1868-1879. [CrossRef]

138. Oh, S.-H.; Lee, S.-M.; Cho, W.-I.; Cho, B.-W. Electrochemical characterization of zirconium-doped $\mathrm{LiNi}_{0.8} \mathrm{Co}_{0.2} \mathrm{O}_{2}$ cathode materials and investigations on deterioration mechanism. Electrochim. Acta 2006, 51, 3637-3644. [CrossRef]

139. Liu, D.; Liu, S.; Zhang, C.; You, L.; Huang, T.; Yu, A. Revealing the effect of Ti doping on significantly enhancing cyclic performance at a high cutoff voltage for $\mathrm{Ni}$-rich $\mathrm{LiNi}_{0.80} \mathrm{Co}_{0.15} \mathrm{Al}_{0.05} \mathrm{O}_{2}$ cathode. ACS Sustain. Chem. Eng. 2019, 7, 10661-10669. [CrossRef]

140. Qiu, Q.-Q.; Shadike, Z.; Wang, Q.-C.; Yue, X.-Y.; Li, X.-L.; Yuan, S.-S.; Fang, F.; Wu, X.-J.; Hunt, A.; Waluyo, I.; et al. Improving the electrochemical performance and structural stability of the $\mathrm{LiNi}_{0.80} \mathrm{Co}_{0.15} \mathrm{Al}_{0.05} \mathrm{O}_{2}$ cathode material at high-voltage charging through Ti substitution. ACS Appl. Mater. Interfaces 2019, 11, 23213-23221. [CrossRef]

141. Huang, Y.; Liu, X.; Yu, R.; Cao, S.; Pei, Y.; Luo, Z.; Zhao, Q.; Chang, B.; Wang, Y.; Wang, X. Tellurium surface doping to enhance the structural stability and electrochemical performance of layered Ni-rich cathodes. ACS Appl. Mater. Interfaces 2019, 11, 40022-40033. [CrossRef]

142. Liang, M.; Sun, Y.; Song, D.; Shi, X.; Han, Y.; Zhang, H.; Zhang, L. Superior electrochemical performance of quasi-concentration-gradient $\mathrm{LiNi}_{0.80} \mathrm{Co}_{0.15} \mathrm{Al}_{0.05} \mathrm{O}_{2}$ cathode material synthesized with multi-shell precursor and new aluminum source. Electrochem. Acta 2019, 300, 426-436. [CrossRef]

143. Tian, R.; Su, J.; Ma, Z.; Song, D.; Shi, X.; Zhang, H.; Li, C.; Zhang, L. Influences of surface Al concentration on the structure and electrochemical performance of core-shell $\mathrm{LiNi}_{0.80} \mathrm{Co}_{0.15} \mathrm{Al}_{0.05} \mathrm{O}_{2}$ cathode material. Electrochim. Acta 2020, 337, 135769. [CrossRef]

144. Natarajan, S.; Moodakare, S.B.; Haridoss, P.; Goplan, R. Concentration gradient-driven aluminum diffusion in a single-step coprecipitation of a compositionally graded precursor for $\mathrm{LiNi}_{0.8} \mathrm{Co}_{0.135} \mathrm{Al}_{0.065} \mathrm{O}_{2}$ with mitigated irreversibility of $\mathrm{H} 2 \leftrightarrow \mathrm{H} 3$ phase transition. ACS Appl. Mater. Interfaces 2020, 12, 34959-34970. [CrossRef]

145. Du, F.; Chen, R.; Zhuang, Y.; Zhu, L.; Cao, H.; Dai, H.; Adkins, J.; Zhou, Q.; Zheng, J. Effect of substitution of cobalt with iron on electrochemical behavior and solid electrolyte interface of $\mathrm{LiNi}_{0.80} \mathrm{Co}_{0.15} \mathrm{Al}_{0.05} \mathrm{O}_{2}$. Appl. Surface Sci. 2019, 484, 374-382. [CrossRef]

146. Xie, H.; Du, K.; Hu, G.; Peng, Z.; Cao, Y. The role of sodium in $\mathrm{LiNi}_{0.8} \mathrm{Co}_{0.15} \mathrm{Al}_{0.05} \mathrm{O}_{2}$ cathode material and its electrochemical behaviors. Phys. Chem. C 2016, 120, 3235-3241. [CrossRef]

147. Gui, S.; Zhang, Q.; Zhuo, H.; Liu, J. Enhancing the electrochemical performance of $\mathrm{LiNi}_{0.80} \mathrm{Co}_{0.15} \mathrm{Al}_{0.05} \mathrm{O}_{2}$ by a facile doping method: Spray-drying doping with liquid polyacrylonitrile. J. Power Sources 2019, 409, 102-112. [CrossRef] 
148. Du, F.; Zhou, Q.; Cao, H.; Dai, H.; Hu, D.; Sun, P.; Adkins, J.; Zheng, J. Confined growth of primary grains towards stabilizing integrated structure of Ni-rich materials. J. Power Sources 2020, 478, 228737. [CrossRef]

149. Chen, T.; Wang, F.; Li, X.; Yan, X.; Wang, H.; Deng, B.; Xie, Z.; Qu, M. Dual functional $\mathrm{MgHPO}_{4}$ surface modifier used to repair deteriorated Ni-rich $\mathrm{LiNi}_{0.8} \mathrm{Co}_{0.15} \mathrm{Al}_{0.05} \mathrm{O}_{2}$ cathode material. Appl. Surface Sci. 2019, 465, 863-870. [CrossRef]

150. Sun, S.; Liu, T.; Niu, Q.; Sun, X.; Song, D.; Liu, H.; Zhou, X.; Ohsaka, T.; Wu, J. Improvement of superior cycle performance of $\mathrm{LiNi}_{0.80} \mathrm{Co}_{0.15} \mathrm{Al}_{0.05} \mathrm{O}_{2}$ cathode for lithium-ion batteries by multiple compound modifications. J. Electroanal. Chem. 2019, 838, 178-185. [CrossRef]

151. Kondo, H.; Baba, N.; Makimura, Y.; Itou, Y.; Kobayashi, T. Model validation and simulation study on the thermal abuse behavior of $\mathrm{LiNi}_{0.80} \mathrm{Co}_{0.15} \mathrm{Al}_{0.05} \mathrm{O}_{2}$-based batteries. J. Power Sources 2020, 448, 227464. [CrossRef]

152. Li, Y.; Wang, S.; Chen, Y.; Lei, T.; Deng, S.; Zhu, J.; Zhang, J.; Guo, J. Achieving superior electrochemical performances on $\mathrm{LiNi}_{0.80} \mathrm{Co}_{0.15} \mathrm{Al}_{0.05} \mathrm{O}_{2}$ cathode materials by cadmium oxide modification. Mater. Chem. Phys. 2020, 240, 122029.

153. Wang, S.; Li, Y.; Liu, S.; Deng, S.; Chen, Y.; Zhu, J.; Zhang, J.; Guo, J.; Chang, S. Superior electrochemical and kinetics performance of $\mathrm{LiNi}_{0.80} \mathrm{Co}_{0.15} \mathrm{Al}_{0.05} \mathrm{O}_{2}$ cathode by neodymium synergistic modifying for lithium ion batteries. J. Electrochem. Soc. 2020, 167, 090509. [CrossRef]

154. Han, U.-G.; Lee, Y.-J.; Cho, G.-B.; Lim, S.-G.; Kim, K.-W.; Ahn, J.-H.; Cho, K.-K. Enhanced electrochemical performances of Ni-rich $\mathrm{LiNi}_{0.80} \mathrm{Co}_{0.15} \mathrm{Al}_{0.05} \mathrm{O}_{2}$ cathode materials by Ti doping or/and $\mathrm{Al}(\mathrm{OH})_{3}$ Coating. Sci. Adv. Mater. 2020, 9, 1283-1288. [CrossRef]

155. Liu, C.; Cao, G.; Wu, J.; Wang, H.; Shao, G. Surficial structure retention mechanism for $\operatorname{LiNi}_{0.80} \mathrm{Co}_{0.15} \mathrm{Al}_{0.05} \mathrm{O}_{2}$ in a full gradient cathode. ACS Appl. Mater. Interfaces 2019, 11, 31991-31996. [CrossRef]

156. Li, X.; Qian, K.; He, Y.-B.; Liu, C.; An, D.; Li, Y.; Zhou, D.; Lin, Z.; Li, B.; Yang, Q.-H.; et al. A dual-functional gel-polymer electrolyte for lithium ion batteries with superior rate and safety performances. Mater. Chem. A 2017, 5, 18888-18895. [CrossRef]

157. Zhang, F.; Wang, C.; Zhao, D.; Yang, L.; Wang, P.; Li, W.; Wang, B.; Li, S. Synergistic effect of sulfolane and lithium difluoro(oxalate)borate on improvement of compatibility for $\mathrm{LiNi}_{0.8} \mathrm{Co}_{0.1} \mathrm{Mn} n_{0.1} \mathrm{O}_{2}$ electrode. Electrochim. Acta 2020, 337, 135727. [CrossRef]

158. Kim, J.; Lee, J.; Ma, H.; Jeong, H.Y.; Cha, H.; Lee, H.; Yoo, Y.; Park, M.; Cho, J. Controllable solid electrolyte interphase in nickel-rich cathodes by an electrochemical rearrangement for stable lithium-ion batteries. Adv. Mater. 2018, 30, 1704309. [CrossRef]

159. Yan, P.; Zheng, J.; Liu, J.; Wang, B.; Cheng, X.; Zhang, Y.; Sun, X.; Wang, C.; Zhang, J.G. Tailoring grain boundary structures and chemistry of Ni-rich layered cathodes for enhanced cycle stability of lithium-ion batteries. Nat. Energy 2018, 3, 600-605. [CrossRef]

160. Wang, J.; Du, C.; Yan, C.; Xu, X.; He, X.; Yin, G.; Zuo, P.; Cheng, X.; Ma, Y.; Gao, Y.; et al. Role of fluorine surface modification in improving electrochemical cyclability of concentration gradient $\mathrm{Li}\left[\mathrm{Ni}_{0.73} \mathrm{Co}_{0.12} \mathrm{Mn}_{0.15}\right] \mathrm{O}_{2}$ cathode material for Li-ion batteries. RSC Adv. 2016, 6, 26307-26316. [CrossRef]

161. Min, K.; Park, K.; Park, S.Y.; Seo, S.-W.; Choi, B.; Cho, E. Improved electrochemical properties of $\mathrm{LiNi}_{0.91} \mathrm{Co}_{0.06} \mathrm{Mn}_{0.03} \mathrm{O}_{2}$ cathode material via Li-reactive coating with metal phosphates. Sci. Rep. 2017, 7, 7151. [CrossRef]

162. Streich, D.; Erk, C.; Gueguen, A.; Müller, P.; Chesneau, F.F.; Berg, E.J. Operando monitoring of early Ni-mediated surface reconstruction in layered lithiated Ni-Co-Mn oxides. J. Phys. Chem. C 2017, 121, 13481-13486. [CrossRef]

163. Bi, Y.; Yang, W.; Du, R.; Zhou, J.; Liu, M.; Liu, Y.; Wang, D. Correlation of oxygen non-stoichiometry to the instabilities and electrochemical performance of $\mathrm{LiNi}_{0.8} \mathrm{Co}_{0.1} \mathrm{Mn}_{0.1} \mathrm{O}_{2}$ utilized in lithium ion battery. J. Power Sources 2015, 283, 211-218. [CrossRef]

164. Li, X.; Xiong, X.; Wang, Z.; Chen, Q. Effect of sintering temperature on cycling performance and rate performance of $\mathrm{LiNi}_{0.8} \mathrm{Co}_{0.1} \mathrm{Mn}_{0.1} \mathrm{O}_{2}$. Trans. Nonferrous Met. Soc. China 2014, 24, 4023-4029. [CrossRef]

165. Zheng, X.; Li, X.; Zhang, B.; Wang, Z.; Guo, H.; Huang, Z.; Yan, G.; Wang, D.; Xu, Y. Enhanced electrochemical performance of $\mathrm{LiNi}_{0.8} \mathrm{Co}_{0.1} \mathrm{Mn}_{0.1} \mathrm{O}_{2}$ cathode materials obtained by atomization co-precipitation method. Ceram. Int. 2016, 42, 644-649. [CrossRef]

166. Yang, J.; Xia, Y. Enhancement on the cycling stability of the layered Ni-rich oxide cathode by In-Situ fabricating nano-thickness cation-mixing layers. J. Electrochem. Soc. 2016, 163, A2665. [CrossRef] 
167. Liang, L.; Hu, G.; Jiang, F.; Cao, Y. Electrochemical behaviours of $\mathrm{SiO}_{2}$-coated $\mathrm{LiNi}_{0.8} \mathrm{Co}_{0.1} \mathrm{Mn}_{0.1} \mathrm{O}_{2}$ cathode materials by a novel modification method. J. Alloys Compd. 2016, 657, 570-581. [CrossRef]

168. Huang, J.; Fang, X.; Wu, Y.; Zhou, L.; Wang, Y.; Jin, Y.; Dang, W.; Wu, L.; Rong, Z.; Chen, X.; et al. Enhanced electrochemical performance of $\mathrm{LiNi}_{0.8} \mathrm{Co}_{0.1} \mathrm{Mn}_{0.1} \mathrm{O}_{2}$ by surface modification with lithium-active $\mathrm{MoO}_{3}$. J. Electroanal. Chem. 2018, 823, 359-367. [CrossRef]

169. Gan, Z.; Hu, G.; Peng, Z.; Cao, Y.; Tong, H.; Du, K. Surface modification of $\mathrm{LiNi}_{0.8} \mathrm{Co}_{0.1} \mathrm{Mn}_{0.1} \mathrm{O}_{2}$ by $\mathrm{WO}_{3}$ as a cathode material for LIB. Appl. Surf. Sci. 2019, 481, 1228-1238. [CrossRef]

170. Li, Y.-C.; Zhao, W.-M.; Xiang, W.; Wu, Z.-G.; Yang, Z.-G.; Xu, C.-L.; Xu, Y.-D.; Wang, E.-H.; Wu, C.-J.; Guo, X.-D.; et al. Promoting the electrochemical performance of $\mathrm{LiNi}_{0.8} \mathrm{Co}_{0.1} \mathrm{Mn}_{0.1} \mathrm{O}_{2}$ cathode via $\mathrm{LaAlO}_{3}$ coating. J. Alloys Compd. 2018, 766, 546-555. [CrossRef]

171. Zhu, W.; Huang, X.; Liu, T.; Xie, Z.; Wang, Y.; Tian, K.; Bu, L.; Wang, H.; Gao, L.; Zhao, J.; et al. Ultrathin $\mathrm{Al}_{2} \mathrm{O}_{3}$ coating on $\mathrm{LiNi}_{0.8} \mathrm{Co}_{0.1} \mathrm{Mn}_{0.1} \mathrm{O}_{2}$ cathode material for enhanced cycleability at extended voltage ranges. Coatings 2019, 9, 92. [CrossRef]

172. Dong, M.; Wang, Z.; Li, H.; Guo, H.; Li, X.; Shih, K.; Wang, J. Metallurgy inspired formation of homogeneous $\mathrm{Al}_{2} \mathrm{O}_{3}$ coating layer to improve the electrochemical properties of $\mathrm{LiNi}_{0.8} \mathrm{Co}_{0.1} \mathrm{Mn}_{0.1} \mathrm{O}_{2}$ cathode material. ACS Sustain. Chem. Eng. 2017, 5, 10199-10205. [CrossRef]

173. Feng, Y.; Xu, H.; Wang, B.; Wang, S.; Ai, L.; Li, S. Enhanced electrochemical performance of $\mathrm{LiNi}_{0.8} \mathrm{Co}_{0.1} \mathrm{Mn}_{0.1} \mathrm{O}_{2}$ cathode materials by $\mathrm{Al}_{2} \mathrm{O}_{3}$ coating. Electrochem. Energy Conv. Stor. 2020, 18, 031005. [CrossRef]

174. Han, B.; Key, B.; Lapidus, S.H.; Garcia, J.C.; Iddir, H.; Vaughey, J.Y.T.; Dogan, F. From coating to dopant: How the transition metal composition affects alumina coatings on Ni-rich cathodes. ACS Appl. Mater. Interfaces 2017, 9, 41291-41302. [CrossRef]

175. Oh, P.; Oh, S.M.; Li, W.; Myeong, S.; Cho, J.; Manthiram, A. High-performance heterostructured cathodes for Lithium-ion batteries with a Ni-rich layered oxide core and a Li-rich layered oxide shell. Adv. Sci. 2016, 3, 1600184. [CrossRef]

176. Song, B. A facile cathode design combining Ni-rich layered oxides with Li-rich layered oxides for lithium-ion batteries. J. Power Sources 2016, 325, 620-629. [CrossRef]

177. Lu, J.; Peng, Q.; Wang, W.Y.; Nan, C.Y.; Li, L.H.; Li, Y.D. Nanoscale coating of $\mathrm{LiMO}_{2}(\mathrm{M}=\mathrm{Ni}, \mathrm{Co}, \mathrm{Mn})$ nanobelts with $\mathrm{Li}^{+}$-conductive $\mathrm{Li}_{2} \mathrm{TiO}_{3}$ : Toward better rate capabilities for Li-ion batteries. J. Am. Chem. Soc. 2013, 135, 1649-1652. [CrossRef]

178. Zhao, E.; Chen, M.; Hu, Z.; Chen, D.; Yang, L.; Xiao, X. Improved cycle stability of high-capacity Ni-rich $\mathrm{LiNi}_{0.8} \mathrm{Mn}_{0.1} \mathrm{Co}_{0.1} \mathrm{O}_{2}$ at high cut-off voltage by $\mathrm{Li}_{2} \mathrm{SiO}_{3}$ coating. J. Power Sources 2017, 343, 345-353. [CrossRef]

179. Zhang, B.; Dong, P.; Tong, H.; Yao, Y.; Zheng, J.; Yu, W.; Zhang, J.; Chu, D. Enhanced electrochemical performance of $\mathrm{LiNi}_{0.8} \mathrm{Mn}_{0.1} \mathrm{Co}_{0.1} \mathrm{O}_{2}$ with lithium-reactive $\mathrm{Li}_{3} \mathrm{VO}_{4}$ coating. J. Alloys Compd. 2017, 706, 198-204. [CrossRef]

180. Zhang, W.; Liang, L.; Zhao, F.; Liu, Y.; Hou, L.; Yuan, C. Ni-rich $\mathrm{LiNi}_{0.8} \mathrm{Co}_{0.1} \mathrm{Mn}_{0.1} \mathrm{O}_{2}$ coated with Li-ion conductive $\mathrm{Li}_{3} \mathrm{PO}_{4}$ as competitive cathodes for high-energy-density lithium ion batteries. Electrochim. Acta 2020, 340, 135871. [CrossRef]

181. Xie, J.; Sendek, A.D.; Cubuk, E.D.; Zhang, X.; Lu, Z.; Gong, Y.; Wu, T.; Shi, F.; Liu, W.; Reed, E.J.; et al. Atomic layer deposition of stable $\mathrm{LiAlF}_{4}$ lithium ion conductive interfacial layer for stable cathode cycling. ACS Nano 2017, 11, 7019-7027. [CrossRef]

182. Manthiram, A.; Song, B.; Li, W. A perspective on nickel-rich layered oxide cathodes for lithium-ion batteries. Energy Storage Mater. 2017, 6, 125-139. [CrossRef]

183. Xu, J.; Lin, F.; Doeff, M.M.; Tong, W. A review of Ni-based layered oxides for rechargeable Li-ion batteries. J. Mater. Chem. A 2017, 5, 874-901. [CrossRef]

184. Liu, W.; Oh, P.; Liu, X.; Lee, M.-J.; Cho, W.; Chae, S.; Kim, Y.; Cho, J. Nickel-rich layered lithium transition-metal oxide for high-energy lithium-ion batteries. Angew. Chem. Int. Ed. 2015, 54, 4440-4457. [CrossRef]

185. Jan, S.S.; Nurgul, S.; Shi, X.Q.; Xia, H.; Pang, H. Improvement of electrochemical performance of $\mathrm{LiNi}_{0.8} \mathrm{Co}_{0.1} \mathrm{Mn}_{0.1} \mathrm{O}_{2}$ cathode material by graphene nanosheets modification. Electrochim. Acta 2014, 149, 86-93. [CrossRef]

186. Peng, Z.; Li, T.; Zhang, Z.; Du, K.; Hu, G.; Cao, Y. Surface architecture decoration on enhancing properties of $\mathrm{LiNi}_{0.8} \mathrm{Co}_{0.1} \mathrm{Mn}_{0.1} \mathrm{O}_{2}$ with building bi-phase $\mathrm{Li}_{3} \mathrm{PO}_{4}$ and $\mathrm{AlPO}_{4}$ by $\mathrm{Al}\left(\mathrm{H}_{2} \mathrm{PO}_{4}\right)_{3}$ treatment. Electrochim. Acta 2020, 338, 135870. [CrossRef] 
187. Feng, Z.; Rajagopalan, R.; Sun, D.; Tang, Y.; Wang, H. In-situ formation of hybrid $\mathrm{Li}_{3} \mathrm{PO}_{4}-\mathrm{AlPO}_{4}-\mathrm{Al}\left(\mathrm{PO}_{3}\right)_{3}$ coating layer on $\mathrm{LiNi}_{0.80} \mathrm{Mn}_{0.1} \mathrm{Co}_{0.1} \mathrm{O}_{2}$ cathode with enhanced electrochemical properties for lithium-ion battery. Chem. Eng. J. 2020, 382, 122959. [CrossRef]

188. Zha, G.; Luo, Y.; Hu, N.; Ouyang, C.; Hou, H. Surface modification of the $\mathrm{LiNi}_{0.8} \mathrm{Co}_{0.1} \mathrm{Mn}_{0.1} \mathrm{O}_{2}$ cathode material by coating with $\mathrm{FePO}_{4}$ with a yolk-shell structure for improved electrochemical performance. ACS Appl. Mater. Interfaces 2020, 12, 36046-36053. [CrossRef]

189. Tong, H.; Dong, P.; Zhang, J.; Zheng, J.; Yu, W.; Wei, K.; Zhang, B.; Liu, Z.; Chu, D. Cathode material $\mathrm{LiNi}_{0.8} \mathrm{Co}_{0.1} \mathrm{Mn}_{0.1} \mathrm{O}_{2} / \mathrm{LaPO}_{4}$ with high electrochemical performance for lithium-ion batteries. J. Alloys Compd. 2018, 764, 44-50. [CrossRef]

190. Li, Q.; Zuang, W.; Li, Z.; Wu, S.; Li, N.; Gao, M.; Li, W.; Wang, J.; Lu, S. Realizing superior cycle stability of a Ni-rich layered $\mathrm{LiNi}_{0.83} \mathrm{Co}_{0.12} \mathrm{Mn}_{0.05} \mathrm{O}_{2}$ cathode with a $\mathrm{B}_{2} \mathrm{O}_{3}$ surface modification. ChemElectroChem 2020, 7, 998-1006. [CrossRef]

191. Zhang, H.; Zhao, H.; Xu, J.; Zhang, J. Optimizing $\mathrm{Li}_{2} \mathrm{O}-2 \mathrm{~B}_{2} \mathrm{O}_{3}$ coating layer on $\mathrm{LiNi}_{0.8} \mathrm{Co}_{0.1} \mathrm{Mn}_{0.1} \mathrm{O}_{2}(\mathrm{NCM} 811)$ cathode material for high-performance lithium-ion batteries. Int. J. Green Energy 2020, 17, 447-455. [CrossRef]

192. Kang, H.S.; Santhoshkumar, P.; Park, J.W.; Sim, G.S.; Nanthagopal, M.; Lee, C.W. Glass ceramic coating on $\mathrm{LiNi}_{0.8} \mathrm{Co}_{0.1} \mathrm{Mn}_{0.1} \mathrm{O}_{2}$ cathode for Li-ion batteries. Korean J. Chem. Eng. 2020, 37, 1331-1339. [CrossRef]

193. Xiong, X.; Ding, D.; Wang, Z.; Huang, B.; Guo, H.; Li, X. Surface modification of $\mathrm{LiNi}_{0.8} \mathrm{Co}_{0.1} \mathrm{Mn}_{0.1} \mathrm{O}_{2}$ with conducting polypyrrole. J. Solid State Electrochem. 2014, 18, 2619-2624. [CrossRef]

194. Chen, S.; He, T.; Su, Y.; Lu, Y.; Bao, L.; Chen, L.; Zhang, Q.; Wang, J.; Chen, R.; Wu, F. Ni-rich $\mathrm{LiNi}_{0.80} \mathrm{Co}_{0.15} \mathrm{Al}_{0.05} \mathrm{O}_{2}$ oxide coated by dual-conductive layers as high performance cathode material for lithium-ion batteries. ACS Appl. Mater. Interfaces 2017, 9, 29732-29743. [CrossRef]

195. Cao, Y.; Qi, X.; Hu, K.; Wang, Y.; Gan, Z.; Li, Y.; Hu, G.; Peng, Z.; Du, K. Conductive polymers encapsulation to enhance electrochemical performance of Ni-rich cathode materials for Li-ion batteries. ACS Appl. Mater. Interfaces 2018, 10, 18270-18280. [CrossRef]

196. Xu, G.-L.; Liu, Q.; Lau, K.K.; Liu, Y.; Liu, X.; Gao, H.; Zhou, X.; Zhuang, M.; Ren, Y.; Li, J. Building ultraconformal protective layers on both secondary and primary particles of layered lithium transition metal oxide cathodes. Nat. Energy 2019, 4, 484-494. [CrossRef]

197. Kim, T.; Ono, L.K.; Qi, Y. Elucidating the mechanism involved in the performance improvement of lithium-ion transition metal oxide battery by conducting polymer. Adv. Mater. Interfaces 2019, 6, 1801785. [CrossRef]

198. Wu, F.; Liu, J.; Li, L.; Zhang, X.; Luo, R.; Ye, Y.; Chen, R. Surface modification of Li-rich cathode materials for lithium-ion batteries with a PEDOT: PSS conducting polymer. ACS Appl. Mater. Interfaces 2016, 8, 23095-23104. [CrossRef]

199. Jerng, S.E.; Chang, B.; Shin, H.; Kim, H.; Lee, T.; Char, K.; Choi, J.W. Pyrazine-linked 2D covalent organic frameworks as coating material for high-nickel layered oxide cathodes in lithium-ion batteries. ACS Appl. Mater. Interfaces 2020, 12, 10597-10606. [CrossRef]

200. Jiang, H.; Li, J.; Lei, Y.; Chen, Y.; Lai, C.; Shi, L.; Peng, C. Stabling $\mathrm{LiNi}_{0.8} \mathrm{Co}_{0.1} \mathrm{Mn}_{0.1} \mathrm{O}_{2}$ by PVP-assisted $\mathrm{LiF}-\mathrm{LaF}_{3}$ layer for lithium ion batteries with improved electrochemical properties at high cut-off voltage. J. Taiwan Inst. Chem. Eng. 2020, 114, 331-334. [CrossRef]

201. Wang, Z.; Zhong, H.; Song, G. Enhancing high-voltage performance of $\mathrm{LiNi}_{0.8} \mathrm{Co}_{0.1} \mathrm{Mn}_{0.1} \mathrm{O}_{2}$ by coating with NASICON fast ionic conductor $\mathrm{Li}_{1.5} \mathrm{Al}_{0.5} \mathrm{Zr}_{1.5}\left(\mathrm{PO}_{4}\right)_{3}$. J. Alloys Compd. 2020, 849, 156467. [CrossRef]

202. Wang, C.; Peng, W.; Li, Z.; Liang, Y.; Zhong, S.; Zhang, Q. Synthesis and characterization of nano $\mathrm{SnO}_{2}$ modification on $\mathrm{LiNi}_{0.8} \mathrm{Co}_{0.1} \mathrm{Mn}_{0.1} \mathrm{O}_{2}$ cathode materials for lithium batteries. Front. Energy Res. 2019, 7, 125. [CrossRef]

203. Ding, G.; Li, Y.; Gao, Y.; Wang, Q.; Zhu, Z.; Jing, X.; Yan, F.; Yue, Z.; Li, X.; Sun, F. Uniform coating of Se on selenophilic surfaces of nickel-rich layered oxide cathode materials for high performance Li-ion batteries. ACS Sustain. Chem. Eng. 2020, 8, 9632-9640. [CrossRef]

204. Chen, X.; Tang, Y.; Fan, C.; Han, S. A highly stabilized single crystalline nickel-rich $\operatorname{LiNi}_{0.8} \mathrm{Co}_{0.1} \mathrm{Mn}_{0.1} \mathrm{O}_{2}$ cathode through a novel surface spinel-phase modification. Electrochim. Acta 2020, 341, 136075. [CrossRef]

205. Ryu, W.-G.; Shin, H.-S.; Park, M.-S.; Kim, H.; Jung, K.-N.; Lee, J.-W. Mitigating induced-storage degradation of Ni-rich Li cathode material by surface tuning with phosphate. Ceram. Int. 2019, 45, 13942-13950. [CrossRef]

206. Hua, C.; Du, K.; Tan, C.; Peng, Z.; Cao, Y.; Hu, G. Study of full concentration-gradient $\mathrm{Li}\left(\mathrm{Ni}_{0.8} \mathrm{Co}_{0.1} \mathrm{Mn}_{0.1}\right) \mathrm{O}_{2}$ cathode material for lithium ion batteries. J. Alloys Compd. 2014, 614, 264-270. [CrossRef] 
207. Sun, Y.-K.; Myung, S.-T.; Kim, M.-H.; Prakash, J.; Amine, K. Synthesis and characterization of $\mathrm{Li}\left[\left(\mathrm{Ni}_{0.8} \mathrm{Co}_{0.1} \mathrm{Mn}_{0.1}\right)_{0.8}\left(\mathrm{Ni}_{0.5} \mathrm{Mn}_{0.5}\right)_{0.2}\right] \mathrm{O}_{2}$ with the microscale core-shell structure as the positive electrode material for lithium batteries. J. Am. Chem. Soc. 2005, 127, 13411-13418. [CrossRef]

208. Sun, Y.-K.; Myung, S.-T.; Shin, H.-S.; Bae, Y.C.; Yoon, C.S. Novel core-shell-structured $\mathrm{Li}\left[\left(\mathrm{Ni}_{0.8} \mathrm{Co}_{0.1} \mathrm{Mn}_{0.1}\right)_{0.8}\left(\mathrm{Ni}_{0.5} \mathrm{Mn}_{0.5}\right)_{0.2} \mathrm{O}_{2}\right.$ via coprecipitation as positive electrode material for lithium secondary batteries. J. Phys. Chem. B 2006, 110, 6810-6815. [CrossRef]

209. Sun, Y.-K.; Myung, S.-T.; Kim, M.-H.; Kim, J.-H. Microscale core-shell structured $\mathrm{Li}\left[\left(\mathrm{Ni}_{0.8} \mathrm{Co}_{0.1} \mathrm{Mn}_{0.1}\right)_{0.8}\left(\mathrm{Ni}_{0.5} \mathrm{Mn}_{0.5}\right)_{0.2}\right] \mathrm{O}_{2}$ as positive electrode material for lithium batteries. Electrochem. Solid-State Lett. 2006, 9, A171-A174. [CrossRef]

210. Sun, Y.-K.; Myung, S.-T.; Park, B.-C.; Amine, K. Synthesis of spherical nano- to microscale core-shell particles $\mathrm{Li}\left[\left(\mathrm{Ni}_{0.8} \mathrm{Co}_{0.1} \mathrm{Mn}_{0.1}\right)_{1-\mathrm{x}}\left(\mathrm{Ni}_{0.5} \mathrm{Mn}_{0.5}\right)_{\mathrm{x}}\right] \mathrm{O}_{2}$ and their applications to lithium batteries. Chem. Mater. 2006, 18, 5159-5163. [CrossRef]

211. Park, B.-C.; Bang, H.J.; Amine, K.; Jung, E.; Sun, Y.-K. Electrochemical stability of core-shell structure electrode for high voltage cycling as positive electrode for lithium ion batteries. J. Power Sources 2007, 174, 658-662. [CrossRef]

212. Sun, Y.-K.; Myung, S.-T.; Park, B.C.; Prakash, J.; Belharouak, I.; Amine, K. High-energy cathode material for long-life and safe lithium batteries. Nat. Mater. 2009, 8, 320-324. [CrossRef]

213. Shi, H.; Wang, X.; Hou, P.; Zhou, E.; Guo, J.; Zhang, J.; Wang, D.; Guo, F.; Song, D.; Shi, X.; et al. Core-shell structured $\mathrm{Li}\left[\left(\mathrm{Ni}_{0.8} \mathrm{Co}_{0.1} \mathrm{Mn}_{0.1}\right)_{0.7}\left(\mathrm{Ni}_{0.45} \mathrm{Co}_{0.1} \mathrm{Mn}_{0.45}\right)_{0.3}\right] \mathrm{O}_{2}$ cathode material for high-energy lithium ion batteries. J. Alloys Compd. 2014, 587, 710-716. [CrossRef]

214. Hua, W.; Schwarz, B.; Azmi, R.; Müller, M.; Dam, M.S.D.; Knapp, M.; Senyshyn, A.; Heere, M.; Missyul, A.; Simonelli, L.; et al. Lithium-ion (de)intercalation mechanism in core-shell layered $\mathrm{Li}(\mathrm{Ni}, \mathrm{Co}, \mathrm{Mn}) \mathrm{O}_{2}$ cathode materials. Nano Energy 2020, 78, 105231. [CrossRef]

215. Jun, D.W.; Yoon, C.S.; Kim, U.H.; Sun, Y.-K. High-energy density core-shell structured $\mathrm{Li}\left[\mathrm{Ni}_{0.95} \mathrm{Co}_{0.025} \mathrm{Mn}_{0.025}\right] \mathrm{O}_{2}$ cathode for lithium-ion batteries. Chem. Mater. 2017, 29, 5048-5052. [CrossRef]

216. Li, Q.; Dang, R.; Chen, M.; Lee, Y.; Hu, Z.; Xiao, X. Synthesis method for long cycle life lithium-ion cathode material: Nickel-rich core-shell $\mathrm{LiNi}_{0.8} \mathrm{Co}_{0.1} \mathrm{Mn}_{0.1} \mathrm{O}_{2}$. ACS Appl. Mater. Interfaces 2018, 10, 17850-17860. [CrossRef]

217. Lu, X.; Li, X.; Wang, Z.; Guo, H.; Yan, G.; Yin, X. A modified co-precipitation process to coat $\mathrm{LiNi}_{1 / 3} \mathrm{Co}_{1 / 3} \mathrm{Mn}_{1 / 3} \mathrm{O}_{2}$ onto $\mathrm{LiNi}_{0.8} \mathrm{Co}_{0.1} \mathrm{Mn}_{0.1} \mathrm{O}_{2}$ for improving the electrochemical performance. Appl. Surf. Sci. 2014, 297, 182-187. [CrossRef]

218. Wu, B.; Lu, W. Mechanical modeling of particles with active core-shell structures for lithium-ion battery electrodes. J. Phys. Chem. C 2017, 121, 19022-19030. [CrossRef]

219. Park, K.-J.; Lim, B.-B.; Choi, M.-H.; Jung, H.-G.; Sun, Y.-K.; Haro, M.; Vicente, N.; Bisquert, J.; Garcia-Belmonte, G. A high-capacity $\mathrm{Li}\left[\mathrm{Ni}_{0.8} \mathrm{Co}_{0.06} \mathrm{Mn}_{0.14}\right] \mathrm{O}_{2}$ positive electrode with a dual concentration gradient for next-generation lithium-ion batteries. J. Mater. Chem. A 2015, 3, 22183. [CrossRef]

220. Lim, B.-B.; Myung, S.-T.; Yoon, C.S.; Sun, Y.-K. Comparative study of Ni-rich layered cathodes for rechargeable lithium batteries: $\mathrm{Li}\left[\mathrm{Ni}_{0.85} \mathrm{Co}_{0.11} \mathrm{Al}_{0.04}\right] \mathrm{O}_{2}$ and $\mathrm{Li}\left[\mathrm{Ni}_{0.84} \mathrm{Co}_{0.06} \mathrm{Mn}_{0.09} \mathrm{Al}_{0.01}\right]_{2}$ with two-step full concentration gradients. ACS Energy Lett. 2016, 1, 283-289. [CrossRef]

221. Yang, Z.; Xiang, W.; Wu, Z.; He, F.; Zhang, J.; Xiao, Y.; Zhong, B.; Guo, X. Effect of niobium doping on the structure and electrochemical performance of $\mathrm{LiNi}_{0.5} \mathrm{Co}_{0.2} \mathrm{Mn}_{0.3} \mathrm{O}_{2}$ cathode materials for lithium ion batteries. Ceram. Int. 2017, 43, 3866-3872. [CrossRef]

222. Jia, X.; Yan, M.; Zhou, Z.; Chen, X.; Yao, C.; Li, D.; Chen, D.; Chen, Y. Nd-doped $\mathrm{LiNi}_{0.5} \mathrm{Co}_{0.2} \mathrm{Mn}_{0.3} \mathrm{O}_{2}$ as a cathode material for better rate capability in high voltage cycling of Li-ion batteries. Electrochim. Acta 2017, 254, 50-58. [CrossRef]

223. Weigel, T.; Schipper, F.; Erickson, E.M.; Susai, F.A.; Markovsky, B.; Aurbach, D. Structural and electrochemical aspects of $\mathrm{LiNi}_{0.8} \mathrm{Co}_{0.1} \mathrm{Mn}_{0.1} \mathrm{O}_{2}$ cathode materials doped by various cations. ACS Energy Lett. 2019, 4, 508-516. [CrossRef]

224. Chen, M.; Zhao, E.; Chen, D.; Wu, M.; Han, S.; Huang, Q.; Yang, L.; Xiao, X.; Hu, Z. Decreasing Li/Ni disorder and improving the electrochemical performances of Ni-rich $\mathrm{LiNi}_{0.8} \mathrm{Co}_{0.1} \mathrm{Mn}_{0.1} \mathrm{O}_{2}$ by Ca doping. Inorg. Chem. 2017, 56, 8355-8362. [CrossRef] 
225. Susai, F.A.; Kovacheva, D.; Chakraborty, A.; Kravchuk, T.; Ravikumar, R.; Talianker, M.; Grinblat, J.; Burstein, L.; Kauffmann, Y.; Major, D.T.; et al. Improving performance of $\mathrm{LiNi}_{0.80} \mathrm{Mn}_{0.1} \mathrm{Co}_{0.1} \mathrm{O}_{2}$ cathode materials for lithium-ion batteries by doping with molybdenum-ions: Theoretical and experimental studies. ACS Appl. Energy Mater. 2019, 2, 4521-4534. [CrossRef]

226. Liang, H.; Wang, Z.; Guo, H.; Wang, J.; Leng, J. Improvement in the electrochemical performance of $\mathrm{LiNi}_{0.8} \mathrm{Co}_{0.1} \mathrm{Mn}_{0.1} \mathrm{O}_{2}$ cathode material by $\mathrm{Li}_{2} \mathrm{ZrO}_{3}$ coating. Appl. Surf. Sci. 2017, 423, 1045-1053. [CrossRef]

227. Song, B.; Li, W.; Oh, S.-M.; Manthiram, A. Long-life nickel-rich layered oxide cathodes with a uniform $\mathrm{Li}_{2} \mathrm{ZrO}_{3}$ surface coating for lithium-ion batteries. ACS Appl. Mater. Interfaces 2017, 9, 9718-9725. [CrossRef]

228. Li, X.; Zhang, K.; Wang, M.; Liu, Y.; Qu, M.; Zhao, W.; Zheng, J. Dual functions of zirconium modification on improving the electrochemical performance of Ni-rich $\mathrm{LiNi}_{0.8} \mathrm{Co}_{0.1} \mathrm{Mn}_{0.1} \mathrm{O}_{2}$. Sustain. Energy Fuels 2018, 2, 413-421. [CrossRef]

229. He, T.; Lu, Y.; Su, Y.; Bao, L.; Tan, J.; Chen, L.; Zhang, Q.; Li, W.; Chen, S.; Wu, F. Sufficient utilization of zirconium ions to improve the structure and surface properties of nickel-rich cathode materials for lithium-ion batteries. ChemSusChem 2018, 11, 1639-1648. [CrossRef]

230. Gao, S.; Zhan, X.; Cheng, Y.-T. Structural, electrochemical and Li-ion transport properties of Zr-modified $\mathrm{LiNi}_{0.8} \mathrm{Co}_{0.1} \mathrm{Mn}_{0.1} \mathrm{O}_{2}$ positive electrode materials for Li-ion batteries. J. Power Sources 2019, 410-411, 45-52. [CrossRef]

231. Han, B.; Xu, S.; Zhao, S.; Lin, G.; Peng, Y.; Chen, L.; Ivey, D.G.; Wang, P.; Wei, W. Enhancing the structural stability of Ni-rich layered oxide cathodes with a preformed Zr-concentrated defective nanolayer. ACS Appl. Mater. Interfaces 2018, 10, 39599-39607. [CrossRef]

232. Li, L.-J.; Wang, Z.-X.; Liu, Q.-C.; Ye, C.; Chen, Z.-Y.; Gong, L. Effects of chromium on the structural, surface chemistry and electrochemical of layered $\mathrm{LiNi}_{0.8-\mathrm{x}} \mathrm{Co}_{0.1} \mathrm{Mn}_{0.1} \mathrm{Cr}_{\mathrm{x}} \mathrm{O}_{2}$. Electrochim. Acta 2012, 77, 89-96. [CrossRef]

233. Zhang, D.; Liu, Y.; Wu, L.; Feng, L.; Jin, S.; Zhang, R.; Jin, M. Effect of Ti ion doping on electrochemical performance of Ni-rich $\mathrm{LiNi}_{0.8} \mathrm{Co}_{0.1} \mathrm{Mn}_{0.1} \mathrm{O}_{2}$ cathode material. Electrochim. Acta 2019, 328, 135086. [CrossRef]

234. Jiang, Y.; Bi, Y.; Liu, M.; Peng, Z.; Huai, L.; Dong, P.; Duan, J.; Chen, Z.; Li, X.; Wang, D.; et al. Improved stability of Ni-rich cathode by the substitutive cations with stronger bonds. Electrochim. Acta 2018, 268, 41-48. [CrossRef]

235. Sun, H.; Cao, Z.; Wang, T.; Lin, R.; Li, Y.; Liu, X.; Zhang, L.; Lin, F.; Huang, Y.; Luo, W. Enabling high rate performance of Ni-rich layered oxide cathode by uniform titanium doping. Mater. Today Energy 2019, 13, 145-151. [CrossRef]

236. Zeng, W.; Chen, Q.; Li, Y.; Chen, C.; Liu, X.; Yuan, M.; Wang, R.; Chen, S.; Xiao, S. Enhanced electrochemical performances of $\mathrm{LiNi}_{0.8} \mathrm{Co}_{0.1} \mathrm{Mn}_{0.1} \mathrm{O}_{2}$ by synergistic modification of sodium ion doping and silica coating. Solid State Ion. 2020, 346, 115214. [CrossRef]

237. Sattar, T.; Lee, S.-H.; Sim, S.-J.; Jin, B.-S.; Kim, H.-S. Effect of Mg-doping on the electrochemical performance of $\mathrm{LiNi}_{0.84} \mathrm{Co}_{0.11} \mathrm{Mn}_{0.05} \mathrm{O}_{2}$ cathode for lithium ion batteries. Int. J. Hydrogen Energy 2020, 45, 19567-19576. [CrossRef]

238. Duan, J.; Hu, G.; Cao, Y.; Tan, C.; Wu, C.; Du, K.; Peng, Z. Enhanced electrochemical performance and storage property of $\mathrm{LiNi}_{0.815} \mathrm{Co}_{0.15} \mathrm{Al}_{0.035} \mathrm{O}_{2}$ via $\mathrm{Al}$ gradient doping. J. Power Sources 2016, 326, 322-330. [CrossRef]

239. Conry, T.E.; Mehta, A.; Cabana, J.; Doeff, M.M. Structural underpinnings of the enhanced cycling stability upon Al-substitution in $\mathrm{LiNi}_{0.45} \mathrm{Mn}_{0.45} \mathrm{Co}_{0.1-y} \mathrm{Al}_{\mathrm{y}} \mathrm{O}_{2}$ positive electrode materials for Li-ion batteries. Chem. Mater. 2012, 24, 3307-3317. [CrossRef]

240. Do, S.J.; Santhoshkumar, P.; Kang, S.H.; Prasanna, K.; Jo, Y.N.; Lee, C.W. Al-Doped $\mathrm{Li}\left[\mathrm{Ni}_{0.78} \mathrm{Co}_{0.1} \mathrm{Mn}_{0.1} \mathrm{Al}_{0.02}\right] \mathrm{O}_{2}$ for high performance of lithium ion batteries. Ceram. Int. 2019, 45, 6972-6977. [CrossRef]

241. Li, Y.-C.; Xiang, W.; Wu, Z.-G.; Xu, C.-L.; Xu, Y.-D.; Xiao, Y.; Yang, Z.-G.; Wu, C.-J.; Lv, G.-P.; Guo, X.-D. Construction of homogeneously $\mathrm{Al}^{3+}$ doped $\mathrm{Ni}$ rich $\mathrm{Ni}-\mathrm{Co}-\mathrm{Mn}$ cathode with high stable cycling performance and storage stability via scalable continuous precipitation. Electrochim. Acta 2018, 291, 84-94. [CrossRef]

242. Kim, U.-H.; Myung, S.-T.; Yoon, C.S.; Sun, Y.-K. Extending the battery life using an Al-Doped $\mathrm{Li}\left[\mathrm{Ni}_{0.76} \mathrm{Co}_{0.09} \mathrm{Mn}_{0.15}\right] \mathrm{O}_{2}$ cathode with concentration gradients for lithium ion batteries. ACS Energy Lett. 2017, 2, 1848-1854. [CrossRef] 
243. Hou, P.; Li, F.; Sun, Y.; Pan, M.; Wang, X.; Shao, M.; Xu, X. Improving Li ${ }^{+}$kinetics and structural stability of nickel-rich layered cathodes by heterogeneous inactive- $\mathrm{Al}^{3+}$ doping. ACS Sustain. Chem. Eng. 2018, 6, 5653-5661. [CrossRef]

244. Dixit, M.; Markovsky, B.; Aurbach, D.; Major, D.T. Unraveling the effects of Al doping on the electrochemical properties of $\mathrm{LiNi}_{0.5} \mathrm{Co}_{0.2} \mathrm{Mn}_{0.3} \mathrm{O}_{2}$ using first principles. J. Electrochem. Soc. 2017, 164, A6359-A6365. [CrossRef]

245. Yang, X.; Tang, Y.; Shang, G.; Wu, J.; Lai, Y.; Li, J.; Qu, Y.; Zhang, Z. Enhanced cyclability and high-rate capability of $\mathrm{LiNi}_{0.88} \mathrm{Co}_{0.095} \mathrm{Mn}_{0.025} \mathrm{O}_{2}$ cathodes by homogeneous $\mathrm{Al}^{3+}$ doping. ACS Appl. Mater. Interfaces 2019, 11, 32015-32024. [CrossRef]

246. Kim, U.H.; Kuo, L.Y.; Kaghazchi, P.; Yoon, C.S.; Sun, Y.-K. Quaternary layered Ni-rich NCMA cathode for lithium-ion batteries. ACS Energy Lett. 2019, 4, 576-582. [CrossRef]

247. Xia, H.; Liu, C.; Shen, L.; Yu, J.; Li, B.; Kang, F.; He, Y.-B. Structure and thermal stability of $\operatorname{LiNi}_{0.8} \mathrm{Co}_{0.15} \mathrm{Al}_{0.05} \mathrm{O}_{2}$ after long cycling at high temperature. J. Power Sources 2020, 450, 227695. [CrossRef]

248. Liang, C.; Kong, F.; Longo, R.C.; Zhang, C.; Nie, Y.; Zheng, Y.; Cho, K. Site-dependent multicomponent doping strategy for $\mathrm{Ni}$-rich $\mathrm{LiNi}_{1-2 \mathrm{y}} \mathrm{Co}_{\mathrm{y}} \mathrm{Mn}_{\mathrm{y}} \mathrm{O}_{2}(\mathrm{y}=1 / 12)$ cathode materials for Li-ion batteries. J. Mater. Chem. A 2017, 5, 25303-25313. [CrossRef]

249. Min, K.; Seo, S.-W.; Song, Y.Y.; Lee, H.S.; Cho, E. A first-principles study of the preventive effects of $\mathrm{Al}$ and $\mathrm{Mg}$ doping on the degradation in $\mathrm{LiNi}_{0.8} \mathrm{Co}_{0.1} \mathrm{Mn}_{0.1} \mathrm{O}_{2}$ cathode materials. Phys. Chem. Chem. Phys. 2017, 19, 1762-1769. [CrossRef]

250. Yuan, A.; tang, H.; Liu, L.; Ying, J.; Tan, L.; Tan, L.; Sun, R. High performance of phosphorus and fluorine co-doped $\mathrm{LiNi}_{0.8} \mathrm{Co}_{0.1} \mathrm{Mn}_{0.1} \mathrm{O}_{2}$ as a cathode material for lithium ion batteries. J. Alloys Compd. 2020, 844, 156210. [CrossRef]

251. Liu, Y.J.; Fan, X.J.; Zhang, Z.Q.; Wu, H.H.; Liu, D.M.; Dou, A.C.; Su, M.R.; Zhang, Q.B.; Chu, D.W. Enhanced electrochemical performance of Li-rich layered cathode materials by combined $\mathrm{Cr}$ doping and $\mathrm{LiAlO}_{2}$ coating. ACS Sustain. Chem. Eng. 2019, 7, 2225. [CrossRef]

252. Xin, F.; Zhou, H.; Chen, X.; Zuba, M.; Chernova, N.; Zhou, G.; Whittingham, M.S. Li-Nb-O Coating/Substitution enhances the electrochemical performance of the $\mathrm{LiNi}_{0.8} \mathrm{Co}_{0.1} \mathrm{Mn}_{0.1} \mathrm{O}_{2}(\mathrm{NCM} 811)$ Cathode. ACS Appl. Mater. Interfaces 2019, 11, 34889-34894. [CrossRef]

253. Li, J.; Zhang, M.; Zhang, D.; Yan, Y.; Li, Z. An effective doping strategy to improve the cyclic stability and rate capability of Ni-rich $\mathrm{LiNi}_{0.8} \mathrm{Co}_{0.1} \mathrm{Mn}_{0.1} \mathrm{O}_{2}$ cathode. Chem. Eng. J. 2020, 402, 126195. [CrossRef]

254. Dong, M.-X.; Li, X.-Q.; Wang, Z.-X.; Li, X.-H.; Guo, H.-J.; Huang, Z.-J. Enhanced cycling stability of La modified $\mathrm{LiNi}_{0.8-\mathrm{x}} \mathrm{Co}_{0.1} \mathrm{Mn}_{0.1} \mathrm{La}_{\mathrm{x}} \mathrm{O}_{2}$ for Li-ion battery. Trans. Nonferrous Met. Soc. China 2017, 27, 1134-1142. [CrossRef]

255. Zhang, M.; Zhao, H.; Tan, M.; Liu, J.; Hu, Y.; Liu, S.; Shu, X.; Li, H.; Ran, Q.; Cai, J.; et al. Yttrium modified $\mathrm{Ni}$-rich $\mathrm{LiNi}_{0.8} \mathrm{Co}_{0.1} \mathrm{Mn}_{0.1} \mathrm{O}_{2}$ with enhanced electrochemical performance as high energy density cathode material at $4.5 \mathrm{~V}$ high voltage. J. Alloys Compd. 2019, 774, 82-92. [CrossRef]

256. Wu, F.; Li, Q.; Chen, L.; Zhang, Q.; Wang, Z.; Lu, Y.; Bao, L.; Chen, S.; Su, Y. Improving the structure stability of $\mathrm{LiNi}_{0.8} \mathrm{Co}_{0.1} \mathrm{Mn}_{0.1} \mathrm{O}_{2}$ by surface perovskite-like $\mathrm{La}_{2} \mathrm{Ni}_{0.5} \mathrm{Li}_{0.5} \mathrm{O}_{4}$ self-assembling and subsurface $\mathrm{La}^{3+}$ doping. ACS Appl. Mater. Interfaces 2019, 11, 36751-36762. [CrossRef]

257. Wu, Q.; Mao, S.; Wang, Z.; Tong, Y.; Lu, Y. Improving $\mathrm{LiNi}_{\mathrm{x}} \mathrm{Co}_{\mathrm{y}} \mathrm{Mn}_{1-x-y} \mathrm{O}_{2}$ cathode electrolyte interface under high voltage in lithium ion batteries. Nano Select 2020, 1, 111-134. [CrossRef]

258. Sari, H.M.K.; Li, X. Controllable cathode-electrolyte interface of $\mathrm{LiNi}_{0.8} \mathrm{Co}_{0.1} \mathrm{Mn}_{0.1} \mathrm{O}_{2}$ for lithium ion batteries: A review. Adv. Energy Mater. 2019, 9, 1901597. [CrossRef]

259. Haregewoin, A.M.; Wotangoa, A.S.; Hwang, B.J. Electrolyte additives for lithium ion battery electrodes: Progress and perspectives. Energy Environ. Sci. 2016, 9, 1955-1988. [CrossRef]

260. Luo, Z.; Zhang, H.; Yu, L.; Huang, D.; Shen, J. Improving long-term cyclic performance of $\mathrm{LiNi}_{0.8} \mathrm{Co}_{0.1} \mathrm{Mn}_{0.1} \mathrm{O}_{2}$ cathode by introducing a film forming additive. J. Electroanal. Chem. 2019, 833, 520-526. [CrossRef]

261. Shen, J.; Chen, H.; Yu, L.; Huang, D.; Luo, Z. 4, 5-difluoro-1, 3-dioxolan-2-one as a film forming additive on $\mathrm{LiNi}_{0.8} \mathrm{Co}_{0.1} \mathrm{Mn}_{0.1} \mathrm{O}_{2} / \mathrm{SiO} @ \mathrm{C}$ full cells. J. Electroanal. Chem. 2019, 834, 1-7. [CrossRef]

262. Ji, W.; Huang, H.; Huang, X.; Zhang, X.; Zheng, D. A redox-active organic cation for safer high energy density Li-ion batteries. J. Mater. Chem. A 2020, 8, 17156-17162. [CrossRef] 
263. Peng, Z.; Cao, X.; Gao, P.; Jia, H.; Ren, X.; Roy, S.; Li, Z.; Zhu, Y.; Xie, W.; Liu, D.; et al. High-power lithium metal batteries enabled by high-concentration acetonitrile-based electrolytes with vinylene carbonate additive. Adv. Func. Mater. 2020, 30, 2001285. [CrossRef]

264. Wan, S.; Chen, S. A dithiol-based new electrolyte additive for improving electrochemical performance of NCM811 lithium ion batteries. Ionics 2020, 26, 6023-6033. [CrossRef]

265. Kong, X.; Liu, J.; Zhang, Y.; Zeng, J.; Zhao, J. An effective electrolyte design to improve the high-voltage performance of high-capacity NCM811 / $\mathrm{SiO}_{\mathrm{x}}$-Gr batteries. Electrochim. Acta 2020, 349, 136356. [CrossRef]

266. Zheng, Y.; Xu, N.; Chen, S.; Liao, Y.; Zhong, G.; Zhang, Z.; Yang, Y. Construction of a stable $\operatorname{LiNi}_{0.8} \mathrm{Co}_{0.1} \mathrm{Mn}_{0.1} \mathrm{O}_{2}$ (NCM811) cathode interface by a multifunctional organosilicon electrolyte additive. ACS Appl. Energy Mater. 2020, 3, 2837-2845. [CrossRef]

267. Li, G.; Liao, Y.; Li, Z.; Xu, N.; Lu, Y.; Lan, G.; Sun, G.; Li, W. Constructing a low-impedance interface on a high-voltage $\mathrm{LiNi}_{0.8} \mathrm{Co}_{0.1} \mathrm{Mn}_{0.1} \mathrm{O}_{2}$ cathode with 2,4,6-Triphenyl boroxine as a film-forming electrolyte additive for Li-ion batteries. ACS Appl. Mater. Interfaces 2020, 12, 37013-37026. [CrossRef]

268. Lan, G.; Xing, L.; Bedrov, D.; Chen, J.; Guo, R.; Che, Y.; Li, Z.; Zhou, H.; Li, W. Enhanced cyclic stability of Ni-rich lithium ion battery with electrolyte film-forming additive. J. Alloys Compd. 2020, 821, 153236. [CrossRef]

269. Liu, H.; Naylor, A.J.; Menon, A.S.; Brant, W.R.; Edström, K.; Younesi, R. Understanding the roles of tris(trimethylsilyl) phosphite (TMSPi) in $\mathrm{LiNi}_{0.8} \mathrm{Co}_{0.1} \mathrm{Mn}_{0.1} \mathrm{O}_{2}$ (NMC811)/Silicon-Graphite (Si-Gr) lithium-ion batteries. Adv. Mater. 2020, 7, 2000277. [CrossRef]

270. Zhao, W.; Zheng, J.; Zou, L.; Jia, H.; Liu, B.; Wang, H.; Engelhard, M.H.; Wang, C.; Xu, W.; Yang, Y.; et al. High voltage operation of Ni-rich NCM cathodes enabled by stable electrode/electrolyte interphases. Adv. Energy Mater. 2018, 8, 1800297. [CrossRef]

271. Pham, H.Q.; Lee, H.-Y.; Hwang, E.-H.; Kwon, Y.-G.; Song, S.-W. Non-flammable organic liquid electrolyte for high-safety and high-energy density Li-ion batteries. J. Power Sources 2018, 404, 13-19. [CrossRef]

272. Pham, H.Q.; Hwang, E.-H.; Kwon, Y.-G.; Song, S.-W. Approaching the maximum capacity of nickel-rich $\mathrm{LiNi}_{0.8} \mathrm{Co}_{0.1} \mathrm{Mn}_{0.1} \mathrm{O}_{2}$ cathodes by charging to high-voltage in a non-flammable electrolyte of propylene carbonate and fluorinated linear carbonates. Chem. Commun. 2019, 55, 1256-1258. [CrossRef]

273. Pham, H.Q.; Tran, Y.H.T.; Han, J.; Song, S.-W. Roles of nonflammable organic liquid electrolyte in stabilizing the interface of the $\mathrm{LiNi}_{0.8} \mathrm{Co}_{0.1} \mathrm{Mn}_{0.1} \mathrm{O}_{2}$ cathode at $4.5 \mathrm{~V}$ and improving the battery performance. Phys. Chem. C 2020, 124, 175-185. [CrossRef]

274. Sun, H.-H.; Manthiram, A. Impact of microcrack generation and surface degradation on a nickel-rich layered $\mathrm{Li}\left[\mathrm{Ni}_{0.9} \mathrm{Co}_{0.05} \mathrm{Mn}_{0.05} \mathrm{O}_{2}\right.$ ] cathode for lithium-ion batteries. Chem. Mater. 2017, 29, 8486-8493. [CrossRef]

275. Kondrakov, A.O.; Geßwein, H.; Galdina, K.; de Biasi, L.; Meded, V.; Filatova, E.O.; Schumacher, G.; Wenzel, W.; Hartmann, P.; Brezesinski, T.; et al. Charge-transfer-induced lattice collapse in Ni-rich NCM cathode materials during delithiation. J. Phys. Chem. C 2017, 121, 24381-24388. [CrossRef]

276. Qiu, W.; Xia, J.; Chen, L.; Dahn, J.R. A study of methyl phenyl carbonate and diphenyl carbonate as electrolyte additives for high voltage $\mathrm{LiNi}_{0.8} \mathrm{Co}_{0.1} \mathrm{Mn}_{0.1} \mathrm{O}_{2} / /$ graphite pouch cells. J. Power Sources 2016, 318, 228-234. [CrossRef]

277. Li, J.; Li, W.; You, Y.; Manthiram, A. Extending the service life of high-Ni layered oxides by tuning the electrode-electrolyte interphase. Adv. Energy Mater. 2018, 8, 1801957. [CrossRef]

278. Beltrop, K.; Klein, S.; Nölle, R.; Wilken, A.; Lee, J.J.; Köster, T.K.-J.; Reiter, J.; Tao, L.; Liang, C.; Winter, M. Triphenylphosphine oxide as highly effective electrolyte additive for graphite/NMC811 lithium ion cells. Chem. Mater. 2018, 30, 2726-2741. [CrossRef]

279. Jo, M.; Park, S.-H.; Lee, H. $\mathrm{NaH}_{2} \mathrm{PO}_{4}$ as an electrolyte additive for enhanced thermal stability of $\mathrm{LiNi}_{0.8} \mathrm{Co}_{0.1} \mathrm{Mn}_{0.1} \mathrm{O}_{2}$ /graphite batteries. J. Electrochim. Soc. 2020, 167, 130502. [CrossRef]

280. Li, X.; Sun, Q.; Wang, Z.; Song, D.; Zhang, H.; Shi, X.; Li, C.; Zhang, L.; Zhu, L. Outstanding electrochemical performances of the all-solid-state lithium battery using Ni-rich layered oxide cathode and sulfide electrolyte. J. Power Sources 2020, 456, 227997. [CrossRef]

281. Cui, Y.; Wang, Y.; Gu, S.; Qian, C.; Chen, T.; Chen, S.; Zhao, J.; Zhang, S. An effective interface-regulating mechanism enabled by non-sacrificial additives for high-voltage nickel-rich cathode. J. Power Sources 2020, 453, 227852. [CrossRef] 
282. Mao, M.; Huang, B.; Li, Q.; Wang, C.; He, Y.-B.; Kang, F. n-situ construction of hierarchical cathode electrolyte interphase for high performance $\mathrm{LiNi}_{0.8} \mathrm{Co}_{0.1} \mathrm{Mn}_{0.1} \mathrm{O}_{2} / \mathrm{Li}$ metal battery. Nano Energy 2020, 78, 105282. [CrossRef]

283. Wood, D.L.; Li, J.; Daniel, C. Prospects for reducing the processing cost of lithium ion batteries. J. Power Sources 2015, 275, 234-242. [CrossRef]

284. Li, J.; Daniel, C.; Wood, D. Materials processing for lithium-ion batteries. J. Power Sources 2011, 196, $2452-2460$. [CrossRef]

285. Bresser, D.; Buchholz, D.; Moretti, A.; Varzi, A.; Passerini, S. Alternative binders for sustainable electrochemical energy storage-the transition to aqueous electrode processing and bio-derived polymers. Energy Environ. Sci. 2018, 11, 3096-3127. [CrossRef]

286. Kazzazi, A.; Bresser, D.; Birrozzi, A.; Von Zamory, J.; Hekmatfar, M.; Passerini, S. Comparative analysis of aqueous binders for high-energy Li-rich NMC as a lithium-ion cathode and the impact of adding phosphoric acid. ACS Appl. Mater. Interfaces 2018, 10, 17214-17222. [CrossRef]

287. Cetinel, F.A.; Bauer, W. Processing of water-based $\mathrm{LiNi}_{1 / 3} \mathrm{Mn}_{1 / 3} \mathrm{Co}_{1 / 3} \mathrm{O}_{2}$ pastes for manufacturing lithium ion battery cathodes. Bull. Mater. Sci. 2014, 37, 1685-1690. [CrossRef]

288. Loeffler, N.; Kim, G.T.; Passerini, S.; Gutierrez, C.; Cendoya, I.; De Meatza, I.; Alessandrini, F.; Appetecchi, G.B. Performance and ageing robustness of graphite/NMC pouch prototypes manufactured through eco-friendly materials and processes. ChemSusChem 2017, 10, 3581-3587. [CrossRef]

289. Du, Z.; Li, J.; Wood, M.; Mao, C.; Daniel, C.; Wood, D.L. Three-dimensional conductive network formed by carbon nanotubes in aqueous processed NMC electrode. Electrochim Acta 2018, 270, 54-61. [CrossRef]

290. Church, B.C.; Kaminski, D.T.; Jiang, J. Corrosion of aluminum electrodes in aqueous slurries for lithium-ion batteries. J. Mater. Sci. 2014, 49, 3234-3241. [CrossRef]

291. Li, S.Y.; Church, B.C. Effect of aqueous-based cathode slurry $\mathrm{pH}$ and immersion time on corrosion of aluminum current collector in lithium-ion batteries. Mater. Corros. 2016, 67, 978987. [CrossRef]

292. Doberdo, I.; Löffler, N.; Laszczynski, N.; Cericola, D.; Penazzi, N.; Bodoardo, S.; Kim, G.T.; Passerini, S. Enabling aqueous binders for lithium battery cathodes - carbon coating of aluminum current collector. J. Power Sources 2014, 248, 1000-1006. [CrossRef]

293. Loeffler, N.; Kim, G.T.; Mueller, F.; Diemant, T.; Kim, J.K.; Behm, R.J.; Passerini, S. In situ coating of $\mathrm{Li}\left[\mathrm{Ni}_{0.33} \mathrm{Mn}_{0.33} \mathrm{Co}_{0.33}\right] \mathrm{O}_{2}$ particles to enable aqueous electrode processing. ChemSusChem 2016, 9, 1112-1117. [CrossRef]

294. Jung, R.; Morasch, R.; Karayaylali, P.; Phillips, K.; Maglia, F.; Stinner, C.; Shao-Horn, Y.; Gasteiger, H.A. Effect of ambient storage on the degradation of Ni-rich positive electrode materials (NMC811) for Li-ion batteries. J. Electrochem. Soc. 2018, 165, A132-A141. [CrossRef]

295. You, Y.; Celio, H.; Li, J.; Dolocan, A.; Manthiram, A. Modified high-nickel cathodes with stable surface chemistry against ambient air for lithium-ion batteries. Angew. Chem. Int. Ed. 2018, 57, 6480-6485. [CrossRef]

296. Zheng, X.; Li, X.; Wang, Z.; Guo, H.; Huang, Z.; Yan, G.; Wang, D. Investigation and improvement on the electrochemical performance and storage characteristics of $\mathrm{LiNiO}_{2}$-based materials for lithium ion battery. Electrochim. Acta 2016, 191, 832-840. [CrossRef]

297. Xiong, X.; Wang, Z.; Yue, P.; Guo, H.; Wu, F.; Wang, J.; Li, X. Washing effects on electrochemical performance and storage characteristics of $\mathrm{LiNi}_{0.8} \mathrm{Co}_{0.1} \mathrm{Mn}_{0.1} \mathrm{O}_{2}$ as cathode material for lithium-ion batteries. J. Power Sources 2013, 222, 318-325. [CrossRef]

298. Wood, M.; Li, J.; Ruther, R.E.; Du, Z.; Self, E.C.; Meyer III, H.M.; Daniel, C.; Belharouak, I.; Wood III, D.L. Chemical stability and long-term cell performance of low-cobalt, Ni-Rich cathodes prepared by aqueous processing for high-energy Li-Ion batteries. Energy Stor. Mater. 2020, 24, 188-197. [CrossRef]

299. Liu, Y.; Wu, H.; Li, K.; Li, H.; Ouyang, D.; Arab, P.P.; Phattharasupakun, N.; Rathore, D.; Johnson, M.; Wang, Y. Cobalt-free core-shell structure with high specific capacity and long cycle life as an alternative to $\mathrm{Li}\left[\mathrm{Ni}_{0.8} \mathrm{Mn}_{0.1} \mathrm{Co}_{0.1}\right] \mathrm{O}_{2}$. J. Electrochem. Soc. 2020, 167, 120533. [CrossRef]

300. Ma, R.; Zhao, Z.; Fu, J.; Lv, H.; Li, C.; Wu, B.; Mu, D.; Wu, F. Tuning cobalt-free nickel-rich layered $\mathrm{LiNi}_{0.9} \mathrm{Mn}_{0.1} \mathrm{O}_{2}$ cathode material for lithium-ion batteries. ChemElectroChem 2020, 7, 2637-2642. [CrossRef]

301. Kim, U.H.; Ryu, H.H.; Kim, J.H.; Mücke, R.; Kaghazchi, P.; Yoon, C.S.; Sun, Y.-K. Microstructure-controlled $\mathrm{Ni}$-rich cathode material by microscale compositional partition for next-generation electric vehicles. $A d v$. Energy Mater. 2019, 9, 1803902. [CrossRef] 
302. Hou, P.; Zhang, H.; Zi, Z.; Zhang, L.; Xu, X. Core-shell and concentration-gradient cathodes prepared via co-precipitation reaction for advanced lithium-ion batteries. J. Mater. Chem. A 2017, 5, 4254-4279. [CrossRef]

303. South Korea's Battery Industry Speeding up the Process of Transitioning to the "Cobalt Zero" Era. Available online: https://english.etnews.com/20200828200001 (accessed on 20 August 2020).

304. Park, K.J.; Jung, H.G.; Kuo, L.Y.; Kaghazchi, P.; Yoon, C.S.; Sun, Y.-K. Improved cycling stability of $\mathrm{Li}\left[\mathrm{Ni}_{0.9} \mathrm{Co}_{0.05} \mathrm{Mn}_{0.05}\right]_{2}$ through microstructure modification by boron doping for Li-ion batteries. Adv. Energy Mater. 2018, 8, 1801202. [CrossRef]

305. Kim, U.H.; Kim, J.H.; Hwang, J.Y.; Ryu, H.H.; Yoon, C.S.; Sun, Y.-K. Compositionally and structurally redesigned high-energy Ni-rich layered cathode for next-generation lithium batteries. Mater. Today 2019, 23, 26-36. [CrossRef]

306. Ryu, H.H.; Park, K.J.; Yoon, D.R.; Aishova, A.; Yoon, C.S.; Sun, Y.-K. Li $\left[\mathrm{Ni}_{0.9} \mathrm{Co}_{0.09} \mathrm{~W}_{0.01}\right]_{2}$ : A new type of layered oxide cathode with high cycling stability. Adv. Energy Mater. 2019, 9, 1902698. [CrossRef]

307. Wang, D.; Zheng, L.; Li, X.; Du, G.; Feng, Y.; Jia, L.; Dai, Z. Effect of high Ni on battery thermal safety. Int. J. Energy Res. 2020, 44, 12158-12168. [CrossRef]

308. Kalluri, S.; Cha, H.; Kim, J.; Lee, H.; Jang, H.; Cho, J. Building high-rate nickel-rich cathodes by self-organization of structurally stable macrovoid. Adv. Sci. 2020, 7, 1902844. [CrossRef]

309. Kim, J.; Lee, H.; Cha, H.; Yoon, M.; Park, M.; Cho, J. Prospect and reality of Ni-rich cathode for commericalization. Adv. Energy Mater. 2018, 8, 1702028. [CrossRef]

310. Guo, X.; Zhang, Y.Z.; Zhang, F.; Li, Q.; Anjum, D.H.; Liang, H.; Pang, H. A novel strategy for the synthesis of highly stable ternary SiOx composites for Li-ion-battery anodes. J. Mater. Chem A 2019, 7, 15969-15974. [CrossRef]

Publisher's Note: MDPI stays neutral with regard to jurisdictional claims in published maps and institutional affiliations. 